UNIVERSIDADE DE SÃO PAULO

FACULDADE DE EDUCAÇÃO

ÂNGELA ESTEVES MODESTO

\title{
CONCEPÇÕES DE GÊNERO EM UM CENTRO DE ATENDIMENTO À SAÚDE DA MULHER
}

SÃO PAULO

2013 


\section{CONCEPÇÕES DE GÊNERO EM UM CENTRO DE ATENDIMENTO À SAÚDE DA MULHER}

Dissertação apresentada ao Programa de PósGraduação em Educação da Faculdade de Educação da Universidade de São Paulo, para obtenção do título de Mestre em Educação.

Área de concentração: Psicologia e Educação.

Orientadora: Profa. Dra. Denise Trento Rebello de Souza.

VERSÃO CORRIGIDA

SÃO PAULO

2013 
AUTORIZO A REPRODUÇÃO E DIVULGAÇÃO TOTAL OU PARCIAL DESTE TRABALHO, POR QUALQUER MEIO CONVENCIONAL OU ELETRÔNICO, PARA FINS DE ESTUDO E PESQUISA, DESDE QUE CITADA A FONTE.

Catalogação na Publicação

Serviço de Biblioteca e Documentação

Faculdade de Educação da Universidade de São Paulo

$37.047 \quad$ Modesto, Ângela Esteves

M691c Concepções de gênero em um centro de atendimento à saúde da mulher / Ângela Esteves Modesto; orientação Denise Trento Rebello de Souza. São Paulo: s.n., 2013.

104 p.; anexos; apêndices

Dissertação (Mestrado - Programa de Pós-Graduação em Educação. Área de Concentração: Psicologia e Educação) - - Faculdade de Educação da Universidade de São Paulo.

1. Gêneros (Grupos Sociais) 2. Mulheres 3. Saúde da Mulher 4. Saúde Reprodutiva I. Souza, Denise Trento Rebello de, orient. 
Nome: Ângela Esteves Modesto

Título: Concepções de gênero em um centro de atendimento à saúde da mulher.

Dissertação apresentada à Faculdade de Educação da Universidade de São Paulo para obtenção do título de Mestre em Educação.

\title{
Aprovado em:
}

\author{
Banca Examinadora
}

Prof. Dr:

Instituição: Assinatura:

Prof. Dr.:

Instituição: Assinatura:

Prof. Dr.:

Instituição: Assinatura: 


\section{AGRADECIMENTOS}

Agradeço imensamente a todos que acreditaram que eu conseguiria. A todos que me apoiaram com palavras e com presença.

Aos que leram meu trabalho e me deram dicas preciosas! Aos que se interessaram pelo tema e disseram que ele valia a pena!

Às amigas e amigos que são minha família conquistada! E à minha família, mãe e pai! Vocês me acompanharam, estimularam, apoiaram e ajudaram em cada tropeço. Muito obrigada!

Agradeço à minha orientadora Denise Trento, por ter entendido e respeitado meu ritmo e por ter sido tão acolhedora na orientação deste trabalho desde o primeiro encontro, quando nos apresentamos e soubemos que coincidentemente nossas famílias viviam na mesma cidade do interior de São Paulo, São Pedro. Muito obrigada, Denise, pela condução, pelos questionamentos, pelas correções e pelos ensinamentos!

Agradeço à banca da qualificação pelo redirecionamento e sugestões dadas ao meu trabalho, que foram fundamentais para que ele tenha se concluído desta forma. Agradeço especialmente à Marília de Carvalho por ter me apresentado às autoras cujas ideias embasaram minha pesquisa. Obrigada!

Obrigada às minhas chefas, chefes e colegas da Visão Mundial, ONG na qual trabalho, por me concederem horários alternativos de trabalho e o tempo de que precisei para concluir esta pesquisa. Muito obrigada!

Obrigada também à minha gata Mimica, que dormiu ao meu lado ao longo dos dias que passei sentada, escrevendo, ronronou e se esfregou nas minhas pernas, fazendo a vida de uma trabalhadora estudante menos solitária. 
Oh, but what have I got?

Oh, what have I got?

Let me tell you what I got And nobody's gonna take away Unless I wanna

I got my hair, on my head My brains, my ears

My eyes, my nose And my mouth, I got my smile My tongue, my chin My neck, my boobs My heart, my soul And my back I got my sex

I got my arms, my hands My fingers, my legs My feet, my toes And my liver Got my blood

I got life, I've got lives I've got headaches, and toothaches, And bad times too like you (Nina Simone, 1968) 


\section{RESUMO}

MODESTO, A. E. Concepções de gênero em um centro de atendimento à saúde da mulher. 2013. 104 f. Dissertação (Mestrado) - Faculdade de Educação, Universidade de São Paulo, são Paulo, 2013.

Esta dissertação se insere no campo dos estudos de gênero. Seu objetivo foi identificar e analisar as concepções de gênero presentes em um centro de atenção à saúde sexual e reprodutiva das mulheres chamado Casa Ser, localizado no extremo leste da cidade de São Paulo. Trata-se de um estudo de caso com enfoque etnográfico cujos dados foram obtidos por meio de observação participante das atividades da instituição, entrevistas e análise documental. As bases teóricas para este estudo foram as obras de Joan Scott e Judith Butler, que problematizaram o conceito de gênero considerando-o como histórico e culturalmente construído. Acredita-se que a discussão crítica sobre gênero possa influenciar a percepção dos sujeitos de maneira que reflitam sobre seus posicionamentos na vida e contribua para a redução das desigualdades geradas por concepções rígidas de gênero que as aprisionam. A Casa Ser, desde sua inauguração, considera fundamental manter a discussão sobre gênero e a promove em todas as atividades oferecidas às usuárias, portanto, caracterizou-se como um local favorável ao desenvolvimento desta investigação. A intenção não foi avaliar o serviço como adequado ou inadequado em relação a critérios pré-determinados, mas sim identificar pontos relevantes sobre como o tema gênero vem sendo trabalhado em uma instituição de saúde, que tipos de conhecimento parecem estar sendo gerados por esse trabalho e o como as pessoas envolvidas com a Casa Ser parecem estar sendo influenciadas por essas discussões. Os dados mostraram que, de forma geral, gênero está sendo considerado como sinônimo de mulher, que é o público alvo da instituição. Foram poucos os homens presentes nas atividades e pouco se falou sobre eles. Quando abordaram os corpos, as atividades foram focadas na fisiologia e na diferenciação entre mulheres e homens, corroborando a lógica binária e o discurso médico dominante, historicamente direcionado ao controle do corpo da mulher. Por outro lado, muitas foram as falas de resistência, com forte incentivo para que as mulheres assumam o controle de seu próprio corpo, para que exerçam sua sexualidade de maneira saudável e também questionaram os padrões comportamentais estabelecidos para mulheres e homens. Há indícios de que a Casa Ser oferece um ambiente de confiança mútua entre usuárias e funcionárias e estas enfatizam o importante papel que a instituição teve na formação e legitimação de suas ideias acerca do gênero.

PALAVRAS-CHAVE: gênero, mulheres, corpo, saúde sexual e reprodutiva. 


\begin{abstract}
MODESTO, A. E. Gender conceptions in a center dedicated to women's health. 2013. 104 f. Dissertação (Mestrado) - Faculdade de Educação, Universidade de São Paulo, são Paulo, 2013.

This dissertation is inserted in the field of gender studies. Its objective was to identify and analyze the gender conceptions present in a center dedicated to women's sexual and reproductive health called Casa Ser, sited at the extreme east of São Paulo city. It is a case study with ethnographic focus which data was obtained through participant observation of the activities, interviews and documental analysis. The theory bases for this study where the works of Scott (1988, 1995 and 2000) and Butler (2002, 2003 and 2009), which discussed the concept of gender considering its historicity and cultural built. We believe that the critical discussion on gender may influence people's perception in a way they reflect about their own positioning in life and contributes to the reduction of the gender inequalities caused by rigid gender conceptions that trap them. Since its inauguration, Casa Ser considers fundamental to maintain the discussions on gender and promotes it in all its activities offered to the service users, therefore it was a favorable place for the development of this research. The intention was not to evaluate the service as adequate or inadequate according to pre-determined criteria, but to identify relevant issues on how the theme gender have been approached in an health center, which kinds of knowledge about gender seems to be generated by the work and how the involved people seems to be influenced by those discussions. The data showed that, in general, gender is been considered as a synonym for woman, the target population of Casa Ser. A few men took part of the activities and a few was spoken about them. When referred to the bodies, the activities focused the physiology and the differentiation between women and men, corroborating the binary logic and the dominant medical speech, historically dedicated to the women's body control. On the other hand, there were many resistance moments with strong incentive so that women assume the control of their own bodies and exercise their sexuality in a healthy way and also questioned the behavioral patterns established for woman and men. There are some evidence that Casa Ser offers an environment of mutual confidence among users and staff and they emphasize the important role that the center assumed in their formation and legitimation of their ideas about gender.
\end{abstract}

KEY WORDS: gender, women, body, sexual and reproductive health. 


\section{LISTA DE SIGLAS}

CEU - Centro Educacional Unificado

CID - Classificação Estatística Internacional de Doenças e Problemas Relacionados à Saúde

$\mathrm{CM}$ - Coordenadoria da Mulher

COHAB - Companhia de Habitação Popular

CPI - Comissão Parlamentar de Inquérito

CRM - Centro de Referência da Mulher

DDM - Delegacia de Defesa da Mulher

DIU - Dispositivo Intrauterino

DSTs - Doenças Sexualmente Transmissíveis

FESP-SP - Fundação Escola de Sociologia e Política de São Paulo

HTPC - Horário de Trabalho Pedagógico Coletivo

IDH - Índice de Desenvolvimento Humano

INCA - Instituto Nacional do Câncer

IP - Instituto de Psicologia

IPVS - Índice Paulista de Vulnerabilidade Social

LGBTTT - Lésbicas, Gays, Bissexuais, Transexuais, Travestis e Transgêneros

ODM - Objetivos do Milênio

OMS - Organização Mundial de Saúde

ONG - Organização Não Governamental

ONU - Organização das Nações Unidas

PAISM - Programa de Assistência Integral à Saúde da Mulher

PCN - Parâmetros Curriculares Nacionais

PNUD - Programa das Nações Unidas para o Desenvolvimento

SMS - Secretaria Municipal de Saúde

UNESP - Universidade Estadual Paulista Júlio de Mesquita Filho

UNIFEM ou ONU Mulheres - Entidade das Nações Unidas para a Igualdade de Gênero e o Empoderamento das Mulheres

USP - Universidade de São Paulo 


\section{SUMÁRIO}

INTRODUÇÃO ...................................................................................................................................11

1 DEFINIÇÕES INTRODUTÓRIAS ................................................................................16

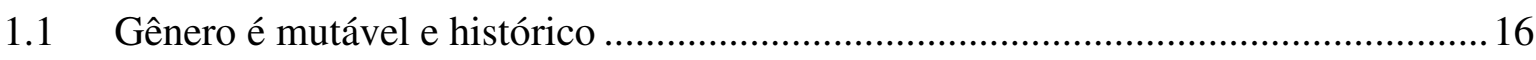

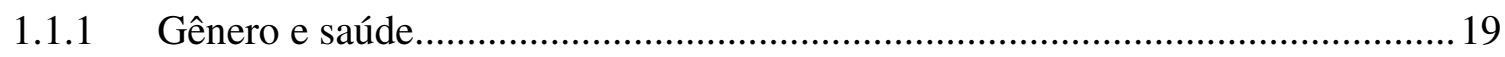

1.2 Contextualização do objeto de estudo e problema de pesquisa ...............................21

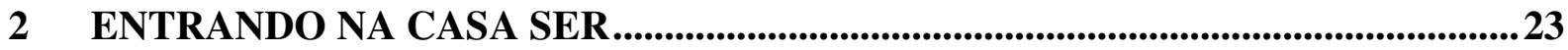

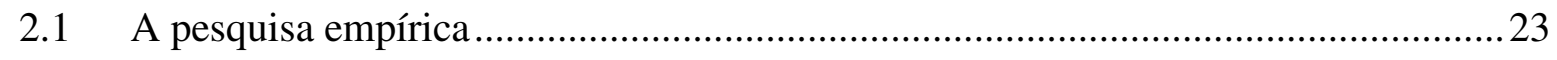

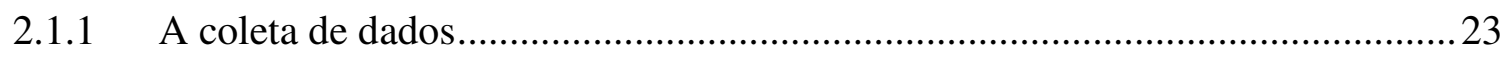

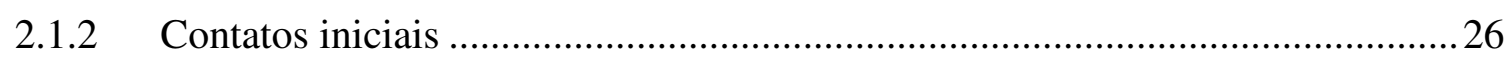

2.1.3 A primeira visita e as primeiras impressões: análise de uma entrevista.............27

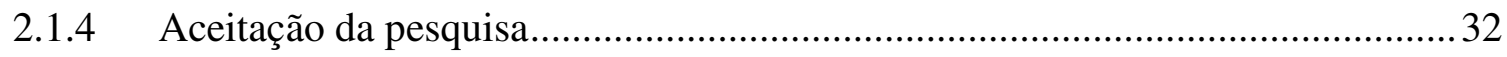

2.2 Os Centros de Referência na cidade de São Paulo ....................................................33

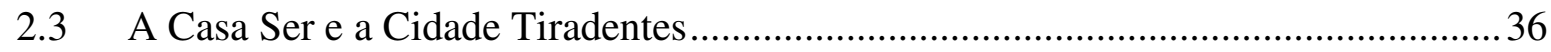

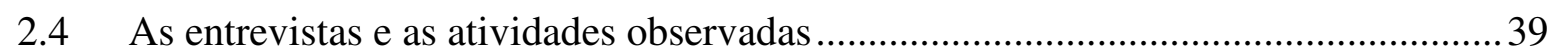

3 CONCEPÇÕES DE GÊNERO: SOBRE O QUÊ SE ESTÁ FALANDO E COMO? 45

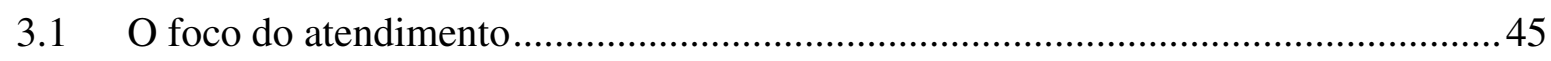



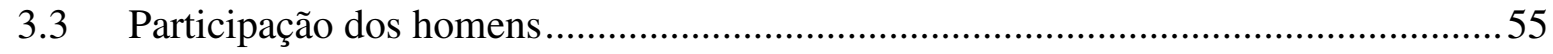

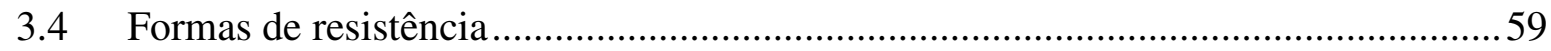

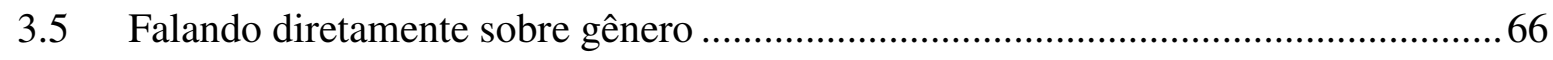

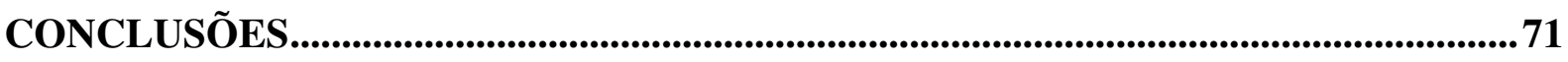

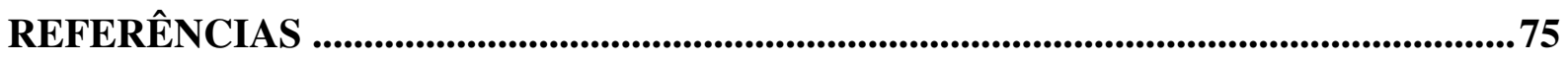

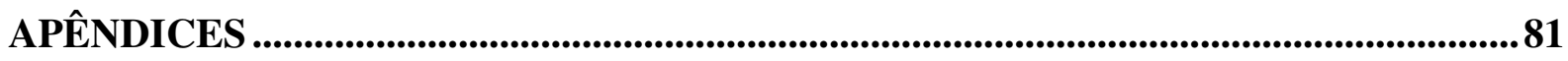

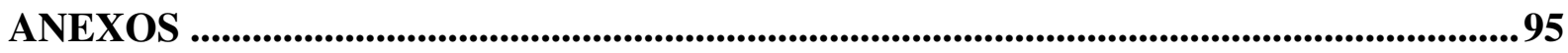




\section{INTRODUÇÃO}

Desde a graduação em Psicologia já me interessava por temas que, hoje sei, tangem o gênero. Durante dois anos aproximadamente, fiz parte de um grupo de pesquisa que investigava inter-relações entre manifestações de pânico, distúrbios do sono e alcoolismo. Meus colegas e eu fizemos entrevistas com mulheres vítimas de violência em Delegacias de Defesa da Mulher (DDM) de Piracicaba, Bauru e São Paulo, sobre os hábitos de sono de seus companheiros. O estudo, no campo da psicobiologia, estava vinculado ao Departamento de Biologia da Universidade Estadual Paulista (UNESP) da cidade de Bauru, no interior de São Paulo. O interesse acabou se concentrando sobre o comportamento da vítima que, na maioria das vezes, permanecia em um relacionamento violento. Considerou-se como violência todo tipo de agressão física, psicológica e sexual cometida contra mulheres no ambiente doméstico. $\mathrm{Na}$ época da pesquisa, o Brasil não contava com uma lei específica que previa medidas judiciais nesses casos e o agressor, quando julgado e condenado, podia pagar com serviços comunitários e em liberdade. A punição para crimes de violência doméstica mudou em 2006, com a chegada da Lei 11.340, conhecida como Lei Maria da Penha. Após sua implantação, todos os crimes de violência doméstica (psicológica, patrimonial, física, moral e sexual) são passíveis de condenação prisional.

Ainda no último ano da graduação (2003), desenvolvi um trabalho sobre sexualidade com professoras e professores de uma escola pública de Bauru. A ideia foi impulsionada pela chegada dos Parâmetros Curriculares Nacionais (PCNs) e pela minha curiosidade acerca de seu conhecimento sobre o tema. Vários encontros foram realizados, coordenados por mim e sob a orientação de Ari Fernando Maia, professor do Departamento de Psicologia, durante o Horário de Trabalho Pedagógico Coletivo (HTPC). Os temas, trabalhados por meio de rodas de conversa, versavam sobre homossexualidade, erotismo, gravidez, sexologia, entre outros. As professoras e professores da escola avaliaram bem os encontros, ressaltando a importância de se incorporar os conteúdos em suas aulas.

Terminada a graduação, continuei participando de um grupo de estudos psicanalíticos na UNESP de Bauru e cursei no ano de 2004 uma disciplina do Departamento de Psicologia Escolar e do Desenvolvimento Humano no Instituto de Psicologia (IP) da Universidade de São Paulo (USP), também com enfoque psicanalítico, chamada A Mulher, o Amor e a Dor, ministrada pela professora Walkiria Helena Grant. Ao final daquele ano, apresentei um 
projeto de pesquisa ao Programa de Pós Graduação do mesmo departamento sobre violência doméstica, com foco psicanalítico. Minha questão era sobre o porquê de as mulheres permanecerem em relacionamentos violentos. Não fui aprovada e pelos quatro anos seguintes fiquei afastada da vida acadêmica.

Durante esse período, estive envolvida com projetos educacionais trabalhando como educadora social. O primeiro deles, no SENAC, era uma proposta de formação de jovens para o mercado de trabalho por meio de temas como empreendedorismo, saúde e qualidade de vida, relacionamento pessoal, etc. O outro projeto, o PROJOVEM, do Governo Federal, tinha igualmente um viés de formação para o trabalho, sendo também um curso conclusão da educação básica para jovens que não a tinham finalizado ou que por algum motivo haviam abandonado a escola.

No final do ano de 2006, comecei a trabalhar para a ONG Visão Mundial - onde trabalho até hoje - que atua em diversas frentes (agroecologia, saúde, educação, políticas públicas, etc.). Apesar de exercer, então, uma função administrativa, sempre estive envolvida com as ações no campo, junto à população beneficiária. Para me preparar melhor para um dos projetos de campo, cursei, como aluna especial, a disciplina Psicologia e Políticas Públicas, ministrada pela professora Ianni Regia Scarcelli, também no IP.

De 2008 a 2010, fiz um curso de especialização em Globalização e Cultura na Fundação Escola de Sociologia e Política de São Paulo (FESP-SP), quando conheci autores das Ciências Sociais, além de voltar a praticar a leitura e escrita de trabalhos acadêmicos. Nessa época, envolvi-me em um projeto da ONG que tinha o foco em gênero e aí começaria minha reaproximação com o tema.

No ano de 2009 a ONG e outras duas organizações fizeram parte da parceria responsável pela gestão do Centro de Referência da Mulher (CRM), um serviço público vinculado à prefeitura de São Paulo, que oferecia atendimento jurídico, social e psicológico às mulheres em situação de vulnerabilidade social da região central da cidade. A maior parte das mulheres usuárias do serviço era encaminhada de DDMs.

Gênero, como tema, sempre permeou os trabalhos desenvolvidos pela Visão Mundial, porém a participação na gestão do CRM foi a primeira ação especificamente focada nessa questão. Participei do projeto como psicóloga, atendendo diretamente as mulheres. Além dos atendimentos, eram oferecidas às usuárias oficinas, aulas de línguas e teatro, todas as atividades visando ao desenvolvimento de sua independência, emancipação e inserção no mercado de trabalho. 
Ao final do contrato para a gestão, a ONG se comprometeu a fazer uma avaliação de impacto das ações do Centro e fui convocada a realiza-la. Entrevistei usuárias, acompanhei as atividades e durante as oficinas profissionalizantes fiquei intrigada com o fato de elas não parecerem proporcionar às mulheres a possibilidade de independência financeira, mas, pelo contrário, reproduzirem conhecimentos do senso comum acerca das diferenças entre homens e mulheres e reforçarem a mulher como frágil e vitimizada. Esse dado me chamou muito a atenção, pois a proposta das atividades era justamente de aproveitar os momentos em grupo para que as usuárias compartilhassem experiências e pudessem aprender umas com as outras, sempre mediadas por uma oficineira que deveria conduzir as discussões questionando determinados papéis atribuídos às mulheres que as colocam em situação de desvantagem em relação aos homens. As falas apareceram impregnadas de justificativas biológicas e hormonais, chegando às vezes a ser deterministas e justificadas pela máxima "ser mulher é assim mesmo".

Concluí, após a análise dos dados, que algumas atividades acabavam corroborando ideias com as quais deveriam romper, de acordo com a proposta de trabalho e com o posicionamento assumido como instituição. Ora, se se pretendia com as discussões promover reflexões transformadoras e que possibilitassem às mulheres vislumbrar alternativas para suas vidas e, consequentemente, maiores independência e possibilidade de sair de situações de violência, os dados mostraram certa limitação.

No ano de 2010 fui, então, aprovada no programa de mestrado da Faculdade de Educação da Universidade de São Paulo, onde pude desenvolver minha pesquisa que buscou responder à seguinte indagação: quais as concepções de gênero presentes em atividades educativas que abordam esse tema? O local escolhido para a investigação foi a Casa Ser, que é um centro de atenção à saúde sexual e reprodutiva de mulheres, localizado no extremo leste da cidade de São Paulo. Os serviços oferecidos são atendimento médico ginecológico, exames preventivos e uma série de atividades de caráter educativo que contemplam questões relacionadas à sexualidade e ao planejamento familiar. De forma geral, pode-se dizer que o trabalho tem um viés notadamente feminista, que visa à emancipação da mulher, além de ter o gênero como eixo estruturante.

Os dados da pesquisa foram coletados por meio de observações participantes e entrevistas, complementados por documentos produzidos pela equipe da Casa Ser desde sua inauguração em 2003. O objetivo da análise foi de identificar concepções de gênero presentes nas diferentes instâncias do trabalho da casa, perceptíveis de maneira explícita - referências diretas em falas de funcionárias, aparição do termo no material consultado - ou implícita - 
opiniões das funcionárias sobre temas diversos, hierarquia da equipe, posicionamento das participantes sobre diferentes questões, entre outras. O material foi analisado até que se pudessem definir algumas categorias mais relevantes.

As principais autoras utilizadas como referência teórica para este trabalho são Joan Scott (1988, 1995 e 2000) e Judith Butler (2002, 2003 e 2009), ambas conhecidas pelas valiosas definições de gênero que elaboraram e suas problematizações. Scott define gênero como "a organização social da diferença sexual" (SCOTT, 1988, p.2) e Butler, posteriormente, argumenta que o gênero é um jogo de práticas ritualizado que acaba por produzir o efeito de uma essência interior (BUTLER, 1990). É essa característica de compreender o gênero como histórico e mutável que as torna fundamentais para as análises realizadas neste estudo. A Casa Ser é impregnada de conhecimentos e significados sobre o corpo, especialmente o corpo das mulheres, onde o esforço por promover a conscientização das usuárias sobre sua condição de mulher e, consequentemente, sobre a condição de seu próprio corpo de mulher, parece ser a estrutura de todo o trabalho.

Sendo assim, o texto está organizado da seguinte maneira: o primeiro capítulo apresenta uma discussão teórica sobre gênero com base nas referências principais para este trabalho, as autoras Scott (1988, 1995 e 2000) e Butler (2002, 2003 e 2009), entre outras que problematizaram a utilização desse conceito. Apresenta também um breve percurso histórico sobre os estudos de gênero no campo da saúde, já que o local em que se conduziu este estudo, a Casa Ser, é um centro de atendimento à saúde sexual e reprodutiva da mulher. Ainda no primeiro capítulo estão expressos o problema e o objetivo desta pesquisa.

O segundo capítulo se dedica à apresentação de meu percurso metodológico até os primeiros contatos com a Casa Ser. Explicito como a investigação se insere no campo da pesquisa qualitativa, sendo um estudo de caso com enfoque etnográfico cujos dados foram obtidos por meio de observação participante, entrevistas e análise documental. Em seguida, apresento a instituição e como ela se insere no contexto da Cidade Tiradentes, distrito localizado ao extremo leste da cidade de São Paulo, e entre os outros Centros de Referência da prefeitura municipal do município. Posteriormente, comento sobre a aceitação da pesquisa dentro da instituição e apresento o relato referente à primeira entrevista realizada com uma das funcionárias, que constituiu meu primeiro contato direto com a Casa Ser.

Finalmente, o terceiro capítulo traz os principais achados desta investigação organizados por tema. A discussão é construída por meio de excertos de entrevistas e de registros de observações analisados com base nas ideias das principais autoras da área de gênero que sustentam este estudo, além de outras referências que se fizeram necessárias no 
sentido de promover reflexões críticas e que pudessem trazer novos conhecimentos e pontos de vista acerca dos conteúdos trabalhados.

As conclusões apresentam as considerações finais sobre a pesquisa e algumas questões relevantes que foram mobilizadas por este estudo e poderão dar margem a investigações futuras. 


\section{DEFINIÇÕES INTRODUTÓRIAS}

\subsection{Gênero é mutável e histórico}

Este estudo se propôs a discutir as concepções de gênero presentes em um centro de atendimento à saúde da mulher. Antes de iniciar essa tarefa, apresenta-se a seguir o percurso teórico que levou às definições básicas sobre as quais este trabalho se desenvolveu.

Sexo e gênero são termos comuns para o feminismo, movimento que busca de diversas formas quebrar as estruturas que justificam direitos diferentes para homens e mulheres. Num determinado período e para certas correntes, os termos se referiam respectivamente ao que é biologicamente dado e ao que é socialmente construído.

A problematização dos termos sexo e gênero parece constituir a discussão central que propõe a teórica feminista Linda Nicholson. Em seu Interpretando o Gênero, Nicholson (2000), a fim de elucidar como determinado grupo de feministas emprega os termos, compara o corpo a um cabide, no qual se podem pendurar várias peças, mas em que comumente se penduram casacos e cachecóis. Ora, peças diferentes podem ser penduradas, como suéteres, ou mesmo casacos e cachecóis de cores e tamanhos diferentes, porém, não se questiona muito sobre essas outras funções do cabide, já que, mais comumente, joga-se sobre ele casacos e cachecóis. A autora propõe que as peças sobre o cabide sejam pensadas como diferentes artefatos culturais relativos à personalidade e comportamento, ou seja, fatores que podem ser muito diferentes de um grupo para outro, de uma cultura para a outra, sem que se altere o cabide. Isto, para Nicholson, caracterizaria o que chama de fundacionalismo biológico: uma noção causal do relacionamento entre corpo (masculino ou feminino), personalidade e comportamento. Segundo Nicholson,

\footnotetext{
A assunção de que tudo o que há em comum entre as mulheres devido ao sexo gera tudo que há em comum entre elas em termos de gênero explica a tendência a se pensar o gênero como representativo do que as mulheres têm em comum, e aspectos de raça, classe como indicativos do que elas têm de diferente. (NICHOLSON, 2000, p.13).
}

Como consequência disto, a autora defende que a ideia de que existem aspectos comuns e imutáveis - originários do corpo - entre todas as mulheres e entre todos os homens obscurece as diferenças existentes entre elas e entre eles. Porém, não haveria, na verdade, aspectos biológicos comuns (Idem, p.14), pois a humanidade difere também quanto às 
inúmeras formas de se compreender o corpo, atribuindo-lhe diferentes sentidos e importância. O corpo é mais uma variável, não uma constante, não sendo possível, portanto, "haver um único conjunto de critérios constitutivos da 'identidade sexual' a partir do qual se possa inferir alguma coisa sobre as alegrias e as opressões inerentes ao 'ser mulher”" (Ibidem, 2000, p.15).

Em seu livro Problemas de Gênero, Judith Butler (2003) chama a atenção para a mesma questão. Ela afirma que o esforço de incluir todas as mulheres em uma categoria única gerou críticas, pois essa categoria desconsiderava dimensões como classe e raça, que diferenciavam as mulheres entre si. Isso quer dizer que a ilusória coerência e unidade da categoria "mulheres" rejeitou justamente a multiplicidade de fatores e características culturais, sociais e políticas que compõe o grupo "mulheres” (BUTLER, 2003).

No campo da história, uma autora constantemente citada pela clareza com que apresenta definições para gênero é Joan Scott. Em um de seus textos, define gênero como "a organização social da diferença sexual" e como "o conhecimento que estabelece os significados para as diferenças corporais" (SCOTT, 1988, p.2). Em outras palavras, o gênero não produz diferenças fixas entre homens e mulheres, mas constitui o discurso sobre as diferenças entre os corpos, que está diretamente ligado às implicações decorrentes deste discurso, isto é, o que será legitimado como verdade e o que não será.

Essas autoras questionam a afirmação feita inicialmente, sobre sexo corresponder ao que é biologicamente dado e gênero ao que é socialmente construído, já que todas as afirmações sobre o corpo, seu sexo e sexualidade só são possíveis devido ao gênero que desde sempre dividiu a humanidade entre machos e fêmeas. De acordo com Butler (2003, p. 25, aspas originais),

\footnotetext{
Se o sexo é, ele próprio, uma categoria tomada em seu gênero, não faz sentido definir o gênero como a interpretação cultural do sexo. $O$ gênero não deve ser meramente concebido como a inscrição cultural de significado num sexo previamente dado (uma concepção jurídica); tem que designar também o aparato mesmo de produção mediante o qual os próprios sexos são estabelecidos. Resulta daí que o gênero não está para a cultura como o sexo para a natureza; ele é também o meio discursivo/cultural pelo qual a "natureza sexuada" ou "um sexo natural" é produzido e estabelecido como "pré-discursivo", anterior à cultura, uma superfície politicamente neutra sobre a qual age a cultura.
}

Dentro desse regime binário de divisão do mundo em machos e fêmeas, há permissões e proibições no âmbito masculino e outras, diferentes, no âmbito feminino. O jogo de permissão-proibição gera grupos de comportamento que constituem tanto o protocolo que deve ser seguido por homens e mulheres quanto a fonte observável de performances que 
alimenta retroativamente a ideia de que existe uma essência por trás desse protocolo, algo de inato que gere e justifique certos comportamentos e atitudes.

$\mathrm{Na}$ abertura de um de seus textos, Scott (2000), impulsionando teorias que rompam com as estruturas geradas pelo discurso binário, defende que é necessário articular um pensamento alternativo sobre o gênero que transcenda a confirmação ou reversão das hierarquias masculinas e femininas e que seja útil e relevante para a prática política. Ela propõe, como alternativa ao discurso binário, incorporar uma maior diversidade, historicamente variável, mais ampla do que aquela permitida pela oposição mulher-homem, que possa se expressar diferentemente, para propósitos diferentes, em contextos diferentes (SCOTT, 2000, p. 219). Isto implicaria não apenas o abandono de explicações essencialistas, mas também da noção de que todos que estão de cada um dos lados nesse regime binário são iguais, tendo, portanto, as mesmas necessidades, as mesmas dificuldades e os mesmos comportamentos.

Considerou-se para esta pesquisa o fato de que os discursos sobre o gênero (e, consequentemente, sobre o sexo), entre os quais o científico, não estão dissociados da ideia completamente naturalizada da diferença sexual binária a partir da qual todo conhecimento é construído, inclusive sobre o corpo; tudo o que é definido como masculino ou feminino já tem raiz na dualidade, na diferenciação.

Judith Butler (2002) nos ajuda a entender a questão ao comentar a materialidade das coisas que são objetos de toda a ação. Ela diz:

Podemos tratar de retornar à matéria entendida como algo anterior ao discurso para embasar nossas afirmações sobre a diferença sexual, mas isto só nos levaria a descobrir que a matéria está completamente sedimentada com os discursos sobre o sexo e a sexualidade, que preexistem e restringem os usos que se podem dar ao termo. (BUTLER, 2002, p.56, tradução minha).

A bióloga Anne Fausto-Sterling (2002) defende também argumentos relativos a como os conhecimentos passam a fazer parte da fisiologia dos corpos. Ela afirma que a ciência cria verdades acerca da sexualidade que são incorporadas e confirmadas por nossos corpos e dão forma ao nosso ambiente cultural (FAUSTO-STERLING, 2002).

Alguns estudos são recorrentes nos trabalhos que discutem o gênero no campo da saúde. Trata-se de coletâneas que se propõem a revisitar a história da medicina do ponto de vista da medicalização dos corpos - e em especial do corpo da mulher - e assim trazer à tona como se deu a apreensão do discurso sobre gênero nesse campo do conhecimento. As considerações a seguir se baseiam nesses estudos e têm a intenção de apresentar uma 
trajetória desse conceito no campo da saúde da mulher. Esse histórico é relevante, dado que o local onde se desenvolveu esta pesquisa é um centro de atendimento à sua saúde sexual e reprodutiva da mulher e compõe, portanto, esse cenário mais amplo.

\subsubsection{Gênero e saúde}

Como foi dito anteriormente, a definição das diferenças entre homens e mulheres é constantemente afirmada por vários discursos, entre os quais o médico ganha destaque. A necessidade de comprovar marcos naturais intransponíveis ligados ao sexo biológico parece só aumentar, expressa por uma inumerável quantidade de pesquisas sobre hormônios, genes e neurônios que reafirmam, criam e recriam as verdades sobre ser homem e ser mulher na busca incansável da substancialização da diferença (ROHDEN, 2001). Mas isto não foi sempre assim.

Durante muito tempo, desde a antiguidade os aparatos genitais de homens e mulheres foram compreendidos como semelhantes e correspondentes: a vagina era vista como um pênis interno, os lábios como o prepúcio, o útero como o escroto e os ovários como testículos. A variação interna ou externa e outras modificações no aparato eram compreendidas como diferentes graus de perfeição de um mesmo modelo, cujo desenvolvimento estaria suscetível a variações de calor, por exemplo (LAQUEUR, 2001).

No entanto, ao final do século XVIII surge uma tendência que culminou, em última instância, na mudança da compreensão do que se costuma chamar de natureza sexual humana. O que antes parecia se basear na semelhança comparada entre homens e mulheres passou a se pautar em suas diferenças fundamentais. Esse movimento segue pelo século XIX, período de profundas transformações sócio econômicas como a industrialização, acompanhadas por um maior contingente de mulheres ingressando no mercado de trabalho, o que exigiu a revisão das concepções de gênero que, a partir desse momento, não mais comportavam as atitudes e comportamentos que comporiam os papéis sociais assumidos dali em diante.

Essa nova atitude, que era aos poucos assumida diante da mudança contextual, parece ter mobilizado um grande esforço da ciência médica em reafirmar as diferenças entre os sexos e quais eram os papéis que deveriam ocupar homens e mulheres na sociedade; afinal, o que estava em jogo eram questões básicas da organização social como a estrutura familiar, já que 
a mulher que trabalha fora assume responsabilidades para além do cuidado da casa e dos filhos (ROHDEN, 2001).

A ciência da época se dedicava à elaboração de grandes teorias e métodos para a classificação e estabelecimento de fronteiras entre povos, raças e sexos, e estes últimos recaíram de forma massiva sobre o corpo da mulher, que foi tomado "a partir da existência de seus órgãos sexuais e reprodutivos" (PORTELLA, 2005, p. 158), atribuindo-lhe, portanto, a maternidade como sendo seu principal destino. A ginecologia emerge como ciência da mulher, como se ela e suas questões precisassem de maior atenção em relação ao homem, e teve grande papel no estabelecimento e legitimação das diferenças. O controle exercido sobre o corpo das mulheres foi uma das razões contra as quais o movimento feminista ocidental se mobilizou, pois tal controle expressava subordinação e opressão de gênero contra as mulheres (ROHDEN, 2001).

No Brasil, um marco desse processo de atenção às questões da mulher que buscou conciliar as proposições feministas e as advindas do movimento sanitário brasileiro foi o lançamento do Programa de Assistência Integral à Saúde da Mulher (PAISM), em 1983, concomitantemente à Comissão Parlamentar Mista de Inquérito (CPI) do Congresso Nacional que investigava o crescimento populacional. O programa foi formatado no modelo de política pública que visava à assistência da mulher de forma integral, abordando sua saúde de forma global e em todas as fases de seu ciclo vital, de acordo com os princípios de universalidade, integralidade e equidade, norteadores do Sistema Único de Saúde (SUS) (COSTA, 1999; AQUINO, 2005). O PAISM era constituído de:

[...] ações educativas, preventivas, de diagnose, tratamento e/ou recuperação, que, aplicadas integral e permanentemente, objetiva, a melhoria da saúde da população feminina, servindo de molde para qualquer proposta pessoal ou institucional na assistência integral à saúde da mulher. (FORMIGA FILHO, 1999, p.155).

Apesar de estrategicamente focados na contenção do crescimento populacional pela via do controle do corpo da mulher, os conceitos de saúde reprodutiva e sexual previam a participação masculina e incluíam uma perspectiva de gênero, sendo as ações educativas uma forma de modificar as relações de poder implícitas aí. Houve nesse período grande participação de feministas profissionais de saúde que influenciaram as políticas públicas de saúde da mulher, o que garantiria a validade das ações educativas conforme previstas na política. Infelizmente, e acompanhando a complicada trajetória do SUS, as ações previstas pelo PAISM só foram parcialmente implementadas, ficando as atividades educativas em 
segundo plano, o que comprometeu a integralidade do programa e afetou especialmente seu campo formativo-preventivo (Idem, 1999).

O termo "gênero", assim como seus pares "saúde reprodutiva" e "sexualidade", figurou no cenário internacional especialmente nos anos 1990, ao ser incorporado às pautas de importantes eventos como a Conferência Internacional de População e Desenvolvimento em 1994, a Cúpula Mundial de Desenvolvimento Social e a IV Conferência Mundial sobre a Mulher, ambos em 1995, tornando-se frequentes em textos e pesquisas na área da saúde (CORRÊA, 1999). Apesar do uso cada vez mais corrente do termo, sua compreensão e incorporação, seja no nível institucional ou no pessoal, continuam bastante heterogêneas e "Se é vital seguir disseminando estas definições, também é fundamental precisar seus conteúdos [...]" (CORRÊA, 1999, p.39).

\subsection{Contextualização do objeto de estudo e problema de pesquisa}

Este trabalho abordou concepções de gênero tendo por objeto relatos de observações, entrevistas e documentos, a partir de pesquisa realizada na Casa Ser, um centro público de atendimento à saúde sexual e reprodutiva da mulher, localizado na zona leste da cidade de São Paulo.

O local foi escolhido por oferecer, além do atendimento médico ginecológico, várias atividades educativas com foco em gênero, como grupos de discussão e oficinas profissionalizantes. São vários os centros de saúde que oferecem esse tipo de serviço na rede pública de atendimento de São Paulo, mas a Casa Ser foi escolhida por ser reconhecida dentro dessa rede como aquela que realiza um trabalho diferenciado e pelo forte viés de gênero que perpassa suas atividades, sua marca desde a fundação. Mais informações sobre o local e sua história serão apresentadas nos capítulos seguintes.

O conceito de gênero alcançou o campo da saúde e tem sido considerado importante para se analisar criticamente posturas e conhecimentos a partir de questionamentos sobre a tradição médica. Desde o início, a Casa Ser se mostrou o local propício para que emergissem contradições entre discursos que podem seguir caminhos opostos, como o médico e o feminista, por exemplo, que convivem ali e norteiam as atividades oferecidas.

Há maneiras de se abordar a questão do gênero que podem favorecer a construção de sujeitos mais críticos e conscientes sobre as formas de ver e reconhecer as diferenças, assim como há abordagens que tendem a reforçar e cristalizar concepções que acabam contribuindo 
para a reprodução e perpetuação de desigualdades e discriminações. Este campo de oposições constitui basicamente o problema desta pesquisa. Acredita-se que a formação de pessoas críticas, mais capazes de questionar os conteúdos e buscar alternativas seja mais libertadora e estimule sua autonomia.

A abordagem crítica pode ser a oportunidade de se questionar as relações de poder, que estão nas raízes das desigualdades de gênero. Foucault (2000) formula o que chamou de sujeito crítico:

[...] eu diria que a crítica é o movimento pelo qual o sujeito se dá o direito de interrogar a verdade sobre seus efeitos de poder e o poder sobre seus discursos de verdade; pois bem, a crítica será a arte da inservidão voluntária, aquela da indocilidade refletida. A crítica teria essencialmente por função o desassujeitamento no jogo do que se poderia chamar, em uma palavra, a política da verdade. (FOUCAULT, 2000, p.5).

Acredita-se que discursos diferentes, similares, complementares e contraditórios convivem e compõem as instituições e são perceptíveis nas falas das pessoas presentes, na organização do ambiente, na hierarquia da equipe, em posturas assumidas publicamente. Isso é o que se buscou explicitar e analisar nesta investigação, focada especificamente nas concepções de gênero que circulam e ajudam a compor sujeitos individuais e políticos, inseridos num determinado momento histórico e cultural.

Ao se investigar as concepções de gênero presentes na Casa Ser, pretende-se responder a questões como: quais concepções de gênero estão presentes nas falas das profissionais e que permeiam as atividades oferecidas? Quais reflexões são promovidas por meio das concepções de gênero e que tipo de atitudes elas parecem estar mobilizando na vida das usuárias? Da mesma forma que Machin et al. (2011) aponta em recente artigo sobre concepções de gênero, masculinidade e cuidados em saúde, acredita-se que:

Investigar essas questões é importante para identificar como o gênero, ao constituir relações sociais e a condicionar a percepção de mundo dos sujeitos, pode promover mecanismos potencialmente geradores de desigualdades entre homens e mulheres no cotidiano da assistência à saúde. (MACHIN ET AL., 2011, p.4505-4506). 


\section{ENTRANDO NA CASA SER}

\subsection{A pesquisa empírica}

Este trabalho consiste em um estudo de caso com enfoque etnográfico que buscou identificar concepções de gênero presentes em um centro de atenção à saúde da mulher, a Casa Ser. Para levantar esses dados foram realizadas entrevistas semiestruturadas e observações participantes das diversas atividades do centro, além da leitura e análise de documentos produzidos desde sua fundação em 2003.

A opção pela pesquisa qualitativa se deu pelo fato de ela possibilitar a apreensão minuciosa de diferenças, percepções e concepções individuais. A intenção deste estudo é documentar uma realidade e aprofundar as questões emergentes de um contexto específico refletindo sobre suas relações com o contexto social e cultural no qual se insere. Assim,

[...] a descrição feita é apenas uma entre muitas descrições possíveis. O desafio reside em escrever um texto que preserve as características locais específicas e, ao mesmo tempo, tornar o fenômeno estudado inteligível em um contexto mais amplo. (ROCKWELL, 1991, p. 157, tradução minha).

O enfoque etnográfico permite a apreensão da realidade local por meio de sua observação e descrição analítica. Os trabalhos de campo e de análise dos dados desta pesquisa foram baseados na experiência direta e prolongada da pesquisadora com um contexto particular, o que permitiu o afinamento das perguntas da investigação e a possibilidade de identificar algumas respostas, afinal, o trabalho de campo e de análise são parte do mesmo processo de investigação (ROCKWELL, 1981).

\subsubsection{A coleta de dados}

A coleta de dados ocorreu nos anos de 2010, quando realizei a entrevista inicial, e 2011, por meio de visitas semanais entre os meses de agosto e novembro. Foram 
acompanhadas diferentes atividades, geralmente em grupo, realizadas com as usuárias ${ }^{1}$ do serviço. Houve presença de homens em dois únicos momentos. Eles estavam com suas companheiras em atendimento e acabaram participando dos grupos. Nos demais, a presença foi somente de mulheres. Foram sete observações de atividades em grupo: uma palestra com um defensor público sobre a Lei Maria da Penha, um grupo de discussão sobre o resultado do exame Papanicolau ${ }^{2}$, um grupo em aula de artesanato, um grupo de discussão sobre sexualidade com adolescentes e três grupos de discussão sobre planejamento familiar. Os homens estavam presentes em dois dos encontros sobre planejamento familiar.

Além das atividades com usuárias, foram feitas quatro reuniões, duas com a enfermeira Laura ${ }^{3}$, que conduzia grande parte das atividades em grupo, e outras duas com a coordenadora da Casa Ser, Rose. Uma entrevista foi realizada com a recepcionista Leila.

Houve também momentos de observação geral, enquanto eu aguardava por alguma funcionária, ou esperava um grupo começar, ou mesmo quando o interesse era a movimentação geral na sala de espera, onde se concentravam as usuárias que esperavam por atendimento.

Contei também com um material documental datado do ano da fundação da Casa Ser, 2003, que me ajudaram a compreender o contexto e o momento histórico em que a instituição surgiu. Logo na primeira visita, quando fui apresentada para uma das funcionárias, ela disse que teria um material que poderia me interessar e abriu um armário, de onde tirou exemplares de Boletins Informativos (Anexo B) que na época foram distribuídos à população. A funcionária chamou minha atenção, dizendo que eu poderia fotocopiar os jornais e devolver rapidamente a ela, pois aqueles exemplares eram os únicos que restaram e ela os havia guardado com muito cuidado. Ao outro material, intitulado Cartilha para Profissionais de Saúde, só tive acesso após minha pesquisa ter sido autorizada pelo Comitê de Ética. Trata-se de uma apostila que contém desde definições de gênero até dados estatísticos sobre o distrito da Cidade Tiradentes, onde está localizada a instituição.

No total, foram realizadas 15 visitas à Casa Ser, cada uma com duração média de duas horas, o que contabiliza cerca de 30 horas de trabalho de campo. Para cada visita, preparei anteriormente o material que utilizaria, como roteiro de perguntas e guias de observação, ressaltando os aspectos aos quais deveria ficar mais atenta. As entrevistas foram gravadas e

\footnotetext{
${ }^{1}$ Usarei o feminino quando falar de maneira genérica às pessoas usuárias do serviço ou às funcionárias, pois são na grande maioria mulheres.

${ }^{2}$ O Papanicolau é um exame ginecológico de prevenção ao câncer de colo do útero.

${ }^{3}$ Todos os nomes são fictícios.
} 
transcritas por mim. Para as observações, reuniões e outras conversas informais, tinha sempre comigo um caderno de campo em que anotava desde o conteúdo das atividades até percepções, sentimentos e preocupações minhas acerca do que presenciava.

Além das transcrições feitas a partir de gravações das entrevistas, que expressam a tentativa de ser "a versão mais fiel possível do que foi dito e ouvido" (ROCKWELL, 1987, p. 5), um dos formatos para registro das observações foi um relato mais amplo e detalhado, que será chamado de Registro Ampliado (ver exemplos de Registro Ampliado nos Apêndices E e F), elaborado posteriormente a partir das anotações feitas nos cadernos de campo. Tal forma de registrar as informações permitiu que dados significativos para além do conteúdo formal e literal fossem incluídos entre as anotações, como elementos do ambiente, impressões, ideias associadas e sentimentos despertados no pesquisador, que são fundamentais para a interpretação e traduzem o que não se pode negar: a presença do pesquisador, com a bagagem que traz consigo (Idem, p.4). Os registros ampliados são construídos com a finalidade básica de deixar registrado por escrito o máximo possível sobre as visitas, as conversas, as observações procurando ampliar nossa capacidade de 'ver mais', para além do que se supõe saber sobre o local e as relações ali estabelecidas. Daí a importância de se registrar 'tudo', mesmo o aparentemente não significativo, o que não se consegue atribuir significado imediato. Isso auxilia a conhecer mais, a não apenas confirmar hipóteses iniciais. Como nos ensina Rockwell (2009), as transformações mais profundas se processam no pesquisador, em suas concepções e em sua maneira de explicar a realidade social.

O gravador foi usado em duas das atividades em grupo, mas o abandonei por duas razões. Primeiramente por que ficou nítido o desconforto das participantes do grupo de adolescentes quando pedi para liga-lo. Houve risos e comentários como "é melhor tomar cuidado com o que vai falar" e eu não poderia deixar que um gravador inibisse quaisquer manifestações das participantes, que deveriam estar em um espaço onde se sentissem à vontade. Em segundo lugar, porque a qualidade da gravação da atividade grupal foi muito ruim, sendo frequente todas falarem ao mesmo tempo, o que complicou consideravelmente a transcrição. Preferi, então, anotar os conteúdos em meu caderno da forma mais completa possível e posteriormente os transcrevia, já agregando percepções que seriam importantes para a análise e interpretação dos dados.

Cheguei a fazer intervenções durante os grupos que acompanhei, mas permaneci em silêncio grande parte do tempo, anotando o máximo possível de conteúdo das discussões. Não foram registrados apenas os diálogos onde se falou diretamente sobre gênero, mas sim fatos gerais. Contudo, é claro que minha atenção estava direcionada a esses conteúdos e a cada vez 
que eles emergiam as anotações foram mais precisas. Além do conteúdo das discussões, chamaram minha atenção fatos cotidianos bastante reveladores das concepções de gênero presentes no local, como a baixa participação de homens nos grupos e na equipe de profissionais e a falta de material didático sobre métodos contraceptivos para homens. Esses dados serão apropriadamente discutidos no capítulo final.

\subsubsection{Contatos iniciais}

A aproximação com a Casa Ser se deu de forma lenta e gradual. Foi só ao longo das visitas e conversas que tive com pessoas ligadas diretamente ou não ao serviço e à Universidade de São Paulo que ficaram bem delineados o problema de pesquisa e seu objetivo. As primeiras observações e entrevistas foram cruciais para que eu compreendesse que tipo de informação poderia obter dentro do tempo e recursos que teria disponíveis, considerando o que a instituição poderia oferecer.

Para poder iniciar oficialmente a pesquisa, o projeto precisou ser aprovado pelo Comitê de Ética da Secretaria Municipal de Saúde (SMS). Cheguei ao comitê após sucessivas orientações equivocadas dadas por diferentes instâncias da Prefeitura Municipal de São Paulo. Como detalho mais adiante, no item 2.2, a vinculação dos Centros de Referência às secretarias da prefeitura não tem critérios muito claros.

Pensei inicialmente, tomando como base meu trabalho no Centro de Referência da Mulher, que a Casa Ser estaria submetida à Secretaria de Participação e Parceria, ligada à Coordenadoria da Mulher (CM). Descobri, um mês depois e após falar com três pessoas da Casa Ser por telefone, que eu precisaria buscar o comitê de ética da SMS e não a Coordenadoria da Mulher.

Da entrega dos documentos aos pareceres negativos até a aprovação se passaram aproximadamente três meses. Entre os itens que precisaram de definição prévia estava o número de entrevistados da pesquisa, com respectivos critérios de inclusão ou exclusão, coisas que eu pretendia determinar somente após algum período de contato com a Casa Ser. Mesmo assim, estabeleci uma quantidade aproximada de entrevistas e observações para atender à solicitação. Munida da aprovação do comitê, pude, então, iniciar o trabalho de campo. Para aprofundar um pouco o processo de aproximação, conto a seguir como cheguei ao local da pesquisa e como foram as primeiras conversas. 
Soube da existência da Casa Ser por uma colega de trabalho em 2009, quando atuava como psicóloga em um centro de atendimento a mulheres na região central de São Paulo. Ela comentou que havia um centro semelhante na zona leste de São Paulo que desenvolvia um trabalho reconhecidamente bom, especificamente focado em gênero. Com esse comentário em mente e buscando um espaço para desenvolver minha pesquisa sobre o qual eu não tivesse tantas formulações consolidadas, como era o caso do meu então local de trabalho, parti em busca de algum contato do local, para saber, afinal, o que se estava fazendo lá que os destacava.

Essa etapa da investigação coincidiu com o período em que estava cursando a disciplina de Etnografia, que teria como trabalho final a análise de uma entrevista. Pensei que seria muito propício realizar a entrevista com algum representante da Casa Ser, pois eu poderia obter elementos importantes para avaliar a viabilidade da pesquisa.

Procurei pelo nome na internet, mas não havia site nem telefone disponíveis. Consegui um número em meu então local de trabalho. O número era de uma farmácia, que depois soube ser um prédio anexo, de onde me transferiram para uma representante da Casa Ser. Falei com duas pessoas até que, após explicar brevemente a minha intenção, me indicaram que conversasse com a enfermeira Laura dentro de alguns dias, pois ela era funcionária do local desde o início e teria muitas informações para além daquelas que poderia me fornecer a coordenadora, recém-chegada. Liguei no dia combinado e marquei a entrevista diretamente com Laura que, muito solícita e provavelmente percebendo minha preocupação depois que me explicou o caminho para chegar até lá, me ofereceu carona a partir de uma das estações do trem. Agradeci e recusei a carona, pois queria saber como seria chegar até lá utilizando transportes públicos. Minha ideia era, a partir de reflexões que fiz durante a disciplina sobre etnografia, imergir no contexto investigado, o que implicaria muitas visitas, em momentos distintos e com diferentes objetivos, ou seja, o acesso ao local deveria ser minimamente viável. A análise da entrevista inicial com Laura está no item a seguir.

\subsubsection{A primeira visita e as primeiras impressões: análise de uma entrevista}

Entre o agendamento da primeira entrevista com Laura e o dia combinado, dediqueime à elaboração do roteiro. Com base nas discussões feitas sobre entrevistas como instrumento de coleta de dados na disciplina de etnografia por meio de autores como Nadir 
Zago (2003) e José Bleger (1980), procurei desenvolver um roteiro que me ajudasse a manter o foco central, que fosse suficientemente claro e não demasiado longo e que contemplasse minhas curiosidades naquele momento.

Desenvolvi, então, um roteiro breve, para uma entrevista semiestruturada, com 10 perguntas, abertas à reordenação e adaptação de acordo com o desenrolar da conversa. $\mathrm{O}$ roteiro segue anexo (Apêndice B). Eu levaria um gravador para não perder nenhuma informação importante e não faria anotações durante a entrevista. Faria também anotações, a fim de registrar minhas impressões sobre o conteúdo da entrevista, o trabalho desenvolvido, a viabilidade para minha pesquisa, a receptividade, entre outras coisas. A análise dessa primeira entrevista que foi também meu primeiro contato com a Casa Ser está a seguir.

É importante ressaltar que em junho de 2010, data dessa primeira visita, eu ainda não tinha delimitado claramente nem pergunta principal nem objeto de pesquisa. Contudo, parti de temas que julgava serem fundamentais para meus interesses, especialmente considerando a oportunidade de conhecer um pouco mais sobre o trabalho realizado pelo centro.

\section{A) O caminho, a recepção}

Percorrendo um trajeto em que utilizei sequencialmente ônibus, trem, metrô, trem e lotação, levei cerca de três horas para chegar ao local, sem nenhuma complicação que tenha provocado demasiada demora de um ou outro meio de transporte.

Chegando à recepção, cerca de vinte minutos antes do horário combinado, um homem finalizou o atendimento a duas mulheres e me perguntou se precisava de ajuda. $\mathrm{O}$ fato de ser um recepcionista em um centro dedicado ao atendimento a mulheres me chamou a atenção. Disse que agendei a entrevista, ele me disse que Laura não havia chegado e me pediu para aguardar.

Durante a espera, percebi que todas as funcionárias usavam jaleco branco, o que me fez pensar que se tratava de um centro médico. Outro fator significativo foi que algumas das mulheres que chegavam me perguntavam se eu estava ali esperando o "doutor" ou se esperava para "fazer exame", ao que respondia negativamente, informando que estava ali para fazer uma entrevista.

O funcionário não me deu mais nenhum retorno e apenas informou a Laura que eu a aguardava após minha solicitação. Perguntei por que ele não me avisara sobre a chegada dela e ele saiu em direção às salas de atendimento, sem me responder. Relatei a situação: 
Passados 20 minutos do horário combinado, pergunto se Laura havia chegado e o recepcionista me disse que sim. Pergunto por que não me avisou, ele desconversa e sai, sem me responder (...). Outras mulheres que estão ali me olham, acredito que legitimando minha atitude de questionar. (Registro Ampliado).

Enquanto aguardava mais alguns minutos pela chegada de Laura, fui encaminhada em direção às salas de atendimento, muitas com portas fechadas e mulheres esperando sentadas em cadeiras. Sentei-me também. Uma mulher passou por mim, perguntou meu nome e confirmou se era eu quem estava esperando pela entrevista. Digo que sim e ela se identifica como Laura. Logo em seguida, ela pediu autorização a uma das enfermeiras para utilizarmos sua sala, perguntou quanto tempo ia demorar e eu respondi que não muito, uma hora no máximo. Finalmente, ficamos frente a frente e dei início à entrevista.

\section{B) A entrevista}

Bastante influenciada pelo longo trajeto e pela demorada espera, iniciei a apresentação. Ela se desculpou pela demora e pela correria. Disse que não havia problemas e informei que havia chego há uma hora. Ela me interrompeu, espantada, dizendo que já estava lá uma hora atrás, complementando que "o recepcionista deve ter esquecido". Enquanto isso, eu retirei o gravador da bolsa, abri meu caderno no roteiro de perguntas e perguntei se poderia gravar a entrevista, para não perder nenhuma informação e não precisar anotar durante a conversa, ao que ela respondeu positivamente.

Buscando garantir o acordo inicial para a realização da entrevista, como aponta Zago (2003, p. 303), retomei os esclarecimentos dados anteriormente por telefone, dizendo quais meus objetivos e como iria utilizar os dados coletados, ressaltando mais uma vez que se tratava de uma investigação inicial, para selecionar o local de desenvolvimento de meu projeto de pesquisa para o mestrado. Isto ajudaria a não levantar expectativas quanto à escolha da Casa Ser para a pesquisa. Disse que a pesquisa seria desenvolvida na Faculdade de Educação da USP, com foco em gênero e educação. Creio que a retomada da apresentação foi importante, pois pode ter contribuído para o estabelecimento de confiança entre nós, além de amenizar os desentendimentos de horário.

Foi muito difícil que eu deixasse de lado as primeiras impressões sobre o local e que lidasse com a aparente ansiedade de Laura. Isto sem dúvida permeou os primeiros momentos da conversa, cujo conteúdo, surpreendentemente, aos poucos despertou meu interesse e fez com que a entrevista tomasse um rumo diferente, o que me levou a entender a afirmação de 
Zago, ao se referir às respostas: “A riqueza das respostas está diretamente ligada ao interesse que os temas e o desenvolvimento da entrevista representam para a pessoa." (ZAGO, 2003, p.305) Acrescento, para este caso, que tanto a riqueza das respostas quanto a riqueza das perguntas estiveram diretamente relacionadas ao conteúdo do diálogo, mais ainda que à lógica do roteiro.

Logo nas perguntas iniciais, foi possível notar que a Casa Ser tem um histórico peculiar. Ela foi uma reivindicação dos moradores dos conjuntos habitacionais do distrito Cidade Tiradentes, onde também está localizada. Sua abertura foi possível por meio de uma iniciativa da Secretaria de Participação e Parceria da Prefeitura de São Paulo e Governo do Japão, cujo interesse era construir um centro de atendimento médico-ginecológico. Laura destaca que desde o princípio havia um grupo de trabalho consciente de que apenas as atividades médico-ginecológicas não dariam conta das questões de gênero, devendo ser estendidas a atividades de planejamento familiar e educativas nas escolas da área.

Senti necessidade de aprofundar a questão do conceito de gênero, já que Laura mencionou diversas vezes, desde o início, que na Casa Ser se trabalhava "gênero pela via da mulher", "gênero pela via do planejamento familiar", por exemplo. Adiantei a questão e perguntei qual o conceito de gênero que, na opinião de Laura, ajudaria o desenvolvimento do trabalho, ao que ela me responde: "Dos papéis e da construção social, né, dos papéis de poder de homem e mulher e da construção social...". A resposta me surpreendeu, porque trouxe elementos do conceito problematizado por Joan Scott. Esta autora discorre sobre alguns significados dados ao termo em seu texto de 1990, alguns dos quais reproduzo abaixo:

Com a proliferação dos estudos do sexo e da sexualidade, o gênero se tornou uma palavra particularmente útil, porque oferece um meio de distinguir a prática sexual dos papéis atribuídos às mulheres e aos homens.

(...) elemento constitutivo de relações sociais fundadas sobre as diferenças percebidas entre os sexos e como um primeiro modo de dar significado às relações de poder. (SCOTT, 1990, p.7, grifos meus).

Perguntei a Laura se algum autor ou autora embasavam o conceito de gênero apresentado por ela, ao que responde negativamente, acrescentando que suas concepções foram decorrentes do trabalho e do contato com alguns materiais:

Então... Tem material que é... Do próprio Ministério, materiais que a gente... Que acabam aparecendo, alguns textos que acabam aparecendo, mas nada específico assim... Tem aquele, acho que a primeira vez que a gente começou a discutir isso foi por aquele Ser Homem, Ser Mulher, então, eu 
não sei de quem é não... (...). E a gente foi entrando na discussão, aí você vai entrando pelas pessoas que estiveram antes, já nessa discussão, né? (Laura) ${ }^{4}$.

Mais um ponto que reforça a proximidade com o conceito e demonstra a amplitude do trabalho é a atuação nas escolas do bairro. Laura conta que um grupo de alunos foi selecionado para receber uma formação em gênero e depois serem agentes multiplicadores no bairro. Ela contou:

[...] A gente tá com um projeto agora com o Estado, com a Coordenação daqui, né, das escolas do Estado e com um grupo de multiplicadores do Estado. Então a gente tá fazendo a discussão de gênero pelo feminino, qual a construção feminina, aí a gente tá fazendo a construção do masculino e da diversidade. (...) Três encontros, com um grupo de alunos que é selecionado pela escola, um grupo de alunos muito bons... Pra depois eles desenvolverem algum trabalho na escola, por que depois daqui eles vão ter que desenvolver, apresentar projeto pra gente... (Laura).

Neste caso, uma parceria entre a Casa Ser e escolas estaduais tornou possível que se garantisse a discussão sobre relações de gênero com os alunos, ao mesmo tempo em que as atividades não ficaram restritas ao atendimento médico-ginecológico. As informações compartilhadas por Laura se mostraram significativas para uma investigação sobre a operacionalização das discussões sobre gênero por meio da educação, o que pareceu ser uma característica que o distingue dos outros Centros de Referência com trabalhos semelhantes.

Já finalizando a entrevista, muito satisfeita e repensando a possibilidade de desenvolver a pesquisa na Cidade Tiradentes, agradeci a Laura e disse que entraria em contato, fosse para informar sobre as próximas etapas, fosse para avisar caso a pesquisa fosse desenvolvida em outro local. Ela pareceu muito empenhada em me convencer a pesquisar a Casa Ser, levando-me à sala da coordenadora, apresentando-me a ela e a um armário com vários documentos históricos que datam da inauguração do espaço, complementando que para acessar livremente aquele acervo, eu necessitaria da autorização da Coordenadoria da Mulher ${ }^{5}$. A coordenadora forneceu um endereço de email e deixou claro seu desejo de que eu voltasse.

Ainda na saída, como já comentei anteriormente, uma das enfermeiras - a que cedeu a sala para a entrevista - me emprestou uma pasta com jornais da época da inauguração para

\footnotetext{
${ }^{4}$ Pesquisei pelo material citado, Ser Homem, Ser Mulher, mas não encontrei referência a artigos ou publicações.

${ }^{5}$ Como descobri posteriormente, a autorização que necessitaria seria do Comitê de Ética da SMS, não da Coordenadoria da Mulher.
} 
que eu os fotocopiasse na papelaria em frente e os devolvesse em seguida, pois eram exemplares raros. Achei que ela teve muita confiança em mim, considerando que havia estado ali por pouco tempo e pouco ter interagido com ela.

Deixei o local bastante interessada em saber mais sobre as atividades realizadas ali, afinal, vários fatores haviam chamado minha atenção, desde o percurso de ida até a despedida. $\mathrm{O}$ que não parecia novidade se fez intrigante e demonstrou uma realidade que precisaria conhecer melhor, no mesmo sentido para o qual apontam Ezpeleta e Rockwell (1989), sobre a imersão na realidade escolar:

Se o observador não pretende meramente confirmar o que já pressupunha a respeito da escola, ele se espanta quando se depara com situações inexplicáveis por si mesmas, sem relação possível com o que espera que aconteça. A alta frequência e diversidade dessas situações ajudam a convencê-lo de que sabe bem pouco sobre a vida da escola. (EZPELETA; ROCKWELL, 1989, p.16).

\subsubsection{Aceitação da pesquisa}

De maneira geral, não houve resistência por parte das funcionárias com relação à minha presença. Creio que isso se deva ao fato de a Casa Ser ter sido assunto de muitos trabalhos acadêmicos e às pessoas já estarem acostumadas a conviver com pesquisadores no local. Na sala de espera havia vários painéis com os trabalhos realizados que foram expostos em congressos, a maior parte deles sobre atividades de prevenção às doenças sexualmente transmissíveis (DSTs). As funcionárias me apresentavam aos grupos como pesquisadora e explicavam que eu estava ali para observar ou participar daquela atividade. Eu complementava resumindo o objetivo da pesquisa, dizendo que faria anotações para não esquecer depois, que estava interessada em observar a atividade e que teria cuidado com o sigilo das informações coletadas, não divulgando nome de ninguém. Não houve questionamentos à minha presença nem sobre o que eu escrevia. Da mesma forma, nenhuma das participantes se interessou em ler minhas anotações, apesar de ter deixado em aberto essa possibilidade.

Algumas das usuárias vinham falar comigo para saber se eu morava na região, onde estudava e para saber mais detalhes sobre o tema da minha pesquisa. As informações que dei foram recebidas sem surpresa, a não ser quanto à distância que percorria para chegar ali, 
afinal, eu morava do lado oposto da cidade. Credito essa surpresa ao fato de as usuárias e a maioria das funcionárias residirem na região. Havia um tom quase familiar entre as pessoas, que se conheciam das ruas, e os assuntos da sala de espera e da cozinha giravam em torno de acontecimentos do bairro e do distrito.

Meu caderno de campo, apesar de não causar constrangimento, mobilizou momentos curiosos. Durante o grupo de artesanato, a facilitadora Susana pareceu utilizá-lo como aliado quando queria que sua opinião se sobrepusesse a das alunas, ou mesmo quando queria ameaça-las. Ele foi também personagem do desentendimento entre Susana e Simone, uma das alunas. Reproduzo os respectivos trechos abaixo:

\footnotetext{
Simone olha para mim e reclama do jeito que Susana fala com as alunas: "Aqui é igual escola, ela tem as alunas preferidas... olha o jeito que ela fala com elas!" ao que Susana responde: "Ai, ciúmes agora!". Nesse momento, faço algumas anotações para me lembrar desse diálogo e Susana olha para as alunas e lança, apontando para meu caderno: "Toda vez que eu falo, ela anota.".

Susana quer ensinar a Simone a como terminar o chinelo, dizendo: "Querida, olha aqui como faz.". Imediatamente, Simone diz para mim: "Anota aí! É a primeira vez que ela me chama de querida! Anota aí por que isso nunca acontece!". (Relato ampliado).
}

Houve outros momentos curiosos, como quando um funcionário entrou para servir café às participantes de um dos grupos e as mulheres se alvoroçaram, agradecendo a gentileza e fazendo galanteios ao rapaz. Alguém, na tentativa de parar as mulheres, disse, referindo-se a mim, "Tem gente de fora!” e a facilitadora complementou "Ela sabe que é brincadeira!".

Em um dos primeiros grupos de planejamento familiar de que participei, tive a impressão de que as facilitadoras, uma assistente social e uma enfermeira, não estavam confortáveis com minha presença. Acredito que isto se deveu ao fato de que não havia plano de trabalho para aquela atividade e a eu ter presenciado, minutos antes do início do grupo, as facilitadoras conversando rapidamente para definir o que seria trabalhado. Após uma certa tensão inicial, o grupo seguiu sem maiores problemas.

\subsection{Os Centros de Referência na cidade de São Paulo}

Na cidade de São Paulo existem locais onde se oferecem serviços especializados a públicos específicos, estrategicamente situados e vinculados às várias secretarias da 
prefeitura. Esses locais são reconhecidos por ser referência em um determinado tema, ao qual os serviços oferecidos estão associados. Basta uma rápida busca no site $^{6}$ da prefeitura paulistana para se ter uma noção da diversidade de temas e secretarias que compõe o que será chamado de maneira genérica neste trabalho de Centros de Referência. Esta pesquisa foi realizada em um desses locais, chamado Casa Ser, situado no extremo leste da cidade de São Paulo, que está vinculado à Secretaria Municipal de Saúde. Mais detalhes sobre a Casa Ser serão oferecidos no próximo item.

Na primeira conversa que tive com a coordenadora Rose, ela demonstrou insatisfação devida ao fato de a instituição estar vinculada à Secretaria Municipal de Saúde e não à Coordenadoria da Mulher (via Secretaria de Participação e Parceria). De acordo com ela, há pouco apoio para se desenvolver atividades específicas em gênero. O trecho do Registro Ampliado abaixo mostra a questão e minha percepção acerca de seu comentário:

Ela parece, a seguir, querer me situar quanto à situação da Casa em relação à prefeitura. Menciona que ela e a assistente social são "emprestadas" da Coordenadoria de Saúde e podem ser transferidas, devido à natureza do cargo. Diz também que não vê muito sentido em a Casa Ser responder à Secretaria Municipal de Saúde e não à Coordenadoria da Mulher, pois isso a coloca como mais propícia ao desenvolvimento de ações de saúde que de gênero. Pelo tom com que me conta esses fatos, parece bastante insatisfeita. (Registro Ampliado).

Cada Centro de Referência segue a agenda estabelecida pela secretaria à qual está vinculado. Porém, nem sempre esse alinhamento entre agenda e prática se dá de maneira coerente. Há centros que oferecem serviços muito parecidos, a um público alvo com as mesmas características e que, no entanto, fazem parte de Secretarias diferentes. Há, por exemplo, o Centro de Referência da Mulher, vinculado à Secretaria de Participação e Parceria, e há a Casa Ser, vinculada à Secretaria Municipal de Saúde. O primeiro se localiza na região central da cidade e oferece atendimento jurídico, social e psicológico a mulheres vítimas de violência doméstica, além de atividades de formação profissional visando à sua emancipação. A Casa Ser, que fica na zona leste, foca-se na saúde da mulher, oferecendo exames preventivos e atividades educativas e de formação profissional, igualmente almejando a emancipação de suas usuárias. Apesar de terem clara e respectivamente focos social e médico e de estarem em locais distintos, os dois serviços têm aspectos em comum.

\footnotetext{
${ }^{6}$ A consulta foi feita no site oficial da Prefeitura Municipal de São Paulo. Disponível em: http://www.capital.sp.gov.br/portalpmsp/homec.jsp. Acesso em: 23 de fevereiro de 2013.
} 
Na prefeitura de São Paulo, a Coordenadoria da Mulher - órgão que visa a formular, coordenar e acompanhar as políticas públicas referentes à mulher - está vinculado à Secretaria de Participação e Parceria e, portanto, retomando o exemplo acima, apenas o Centro de Referência da Mulher, vinculado à mesma secretaria, segue a agenda dessa Coordenadoria. Isso significa que os recursos para atividades, apoio para divulgação e qualquer outro tipo de incentivo para a Casa Ser fica restrito a um calendário que não engloba principalmente as questões da mulher, mas as de saúde, apesar do viés declarado da instituição ser a causa da mulher desde sua fundação. Daí a insatisfação da coordenadora.

O Apêndice A traz duas tabelas com todos os Centros de Referência que compõem respectivamente as Secretarias de Participação e Parceria e Municipal de Saúde. Nela, pode-se observar que a Casa Ser é denominada como o local onde se realiza colposcopia ${ }^{7}$ na Cidade Tiradentes, o que restringe sua ação à atividade médica e omite a amplitude do trabalho que é de fato conduzido.

Entretanto, foi notória a preocupação da equipe da Casa Ser em manter atividades com foco em gênero apesar de formalmente sua principal função ser abordar a questão da saúde sexual e reprodutiva das mulheres no âmbito médico. Ao relatar, na primeira entrevista, que havia sido iniciado um trabalho de formação em uma das escolas do bairro, Laura demonstra que não parece ser o desejo do corpo de funcionárias que o serviço oferecido se restrinja ao atendimento médico e à realização de exames. Há uma preocupação com a continuidade das ações e com sua amplificação para alcançar um público diverso, que de outra forma poderia não conhecer a Casa Ser. A fala de Laura é reveladora dessa lógica:

[...] então tem esses encontros em cada uma das escolas do Estado. E tem os encontros que eles estão vindo aqui, que a gente está fazendo, passar algumas dinâmicas pra eles trabalharem, né, pra ampliar. Ano passado a gente fez um curso, de formação de lideranças, né, pra essas questões de saúde sexual e reprodutiva, também teve gênero no primeiro momento e pinceladas de gênero em todos, pro pessoal de ONG, associação, pessoal do conselho gestor, pra multiplicar, né? Pra ver diferente e pra falar da saúde de uma forma diferente. (Laura).

Entre os materiais de divulgação a que tive acesso sobre a Casa Ser, destinados a apresentar o serviço às moradoras da Cidade Tiradentes, todos são publicações assinadas pela Coordenadoria da Mulher, com apoio da Secretaria de Participação e Parceria, o que mostra

\footnotetext{
${ }^{7}$ Colposcopia é um exame médico ginecológico no qual se analisa a vulva, a vagina e o colo uterino.
} 
que no início a vinculação entre essas instâncias e a Casa Ser foi bastante próxima e deve ter diminuído ao longo dos anos, ficando a relação mais restrita à SMS.

\subsection{A Casa Ser e a Cidade Tiradentes}

A Casa Ser se localiza no distrito da Cidade Tiradentes, no extremo leste da cidade de São Paulo, distante 35 quilômetros do centro da capital. De acordo com informações da página $^{8}$ da subprefeitura do distrito, no ano de 2010 havia 219.868 habitantes residindo entre as chamadas cidade formal (conjuntos habitacionais e moradias regulares) e cidade informal (favelas e loteamentos habitacionais clandestinos e irregulares), com densidade demográfica aproximada de 15 habitantes por quilômetro quadrado.

Há um material bastante completo, disponível online, chamado Município em Mapas Série Temática ${ }^{9}$ que apresenta a compilação de dados estatísticos da cidade de São Paulo separados por distrito, divulgado pela Secretaria Municipal de Desenvolvimento Urbano. De acordo com esses dados, o Índice de Desenvolvimento Humano (IDH) da Cidade Tiradentes no ano de 2000 (três anos antes da fundação da Casa Ser) ficava entre 0,430 e 0.490, o que é considerado baixo de acordo com os critérios do Programa das Nações Unidas para o Desenvolvimento (PNUD) ${ }^{10}$. É baixo também se comparado ao índice geral do município de São Paulo, que em 2003 foi de 0.841. Sabe-se que o IDH é um índice internacionalmente adotado e que representa a medida resumida do progresso em longo prazo de três dimensões básicas do desenvolvimento humano: renda, educação e saúde.

O Índice Paulista de Vulnerabilidade Social (IPVS) de 2000 revelou que a maior parte dos habitantes do distrito vivia em situação de alta vulnerabilidade, provocada pela combinação de fatores como alto número de chefes de família jovens, baixos níveis de renda e escolaridade, além da presença significativa de crianças pequenas. Isso significa que, em comparação com outras regiões menos vulneráveis da cidade, era maior o risco de que a população da Cidade Tiradentes sofresse com qualquer tipo de adversidade, seja social, ambiental, econômica, etc. e que sua recuperação fosse provavelmente mais lenta.

\footnotetext{
${ }^{8}$ Disponível em: http://www.prefeitura.sp.gov.br/cidade/secretarias/subprefeituras/cidade_tiradentes/. Acesso em: 23 de fevereiro de 2013.

9 Disponível em: http://smdu.prefeitura.sp.gov.br/indices_sociais/. Acesso em: 23 de fevereiro de 2013.

${ }^{10}$ O PNUD é o órgão responsável pelo cálculo do IDH.
} 
Soma-se a esse cenário a questão da violência publica. A série Olhar São Paulo Violência e Criminalidade ${ }^{11}$ indica que o risco de ocorrências de homicídios dolosos no local é alto, figurando entre os maiores da cidade junto aos extremos sul e norte (dados de 20002005).

Segundo o censo realizado pelo Instituto Brasileiro de Geografia e Estatística (IBGE) em 2010, a população é composta por $53 \%$ de mulheres e $47 \%$ de homens, com maioria se declarando pardos (39\%), seguidos por brancos (34\%), pretos $(21 \%)$ e outros $(6 \%)$. O distrito possui a maior concentração de conjuntos habitacionais da América Latina, com mais de 40 mil unidades construídas em sua maior parte na década de 80.

Pensada para ser um bairro dormitório, a Cidade Tiradentes até hoje mantém essa característica devido às poucas oportunidades locais de emprego, o que obriga seus moradores a se deslocarem até o centro da cidade para trabalhar, num trajeto que leva cerca de três horas utilizando transporte público (metrô, trem e ônibus municipal).

É em meio a esse cenário que nasce a Casa Ser. O nome completo da instituição é Centro de Atenção à Saúde Sexual e Reprodutiva Maria Auxiliadora Lara Barcellos, mas é conhecido pelas usuárias e funcionárias como Casa Ser Dorinha ou apenas Casa Ser. O nome é uma homenagem à estudante presa pela ditadura militar em 1969 no Rio de Janeiro, que morreu na Alemanha após longos anos de exílio, em 1974. Ao lado da sala de recepção há um quadro com a foto da personagem inspiradora e sua história. Um ano após sua fundação, a Casa Ser já havia atendido cerca de 10 mil pessoas, a maioria delas concentrada no grupo que passou por consulta ginecológica (dados do Boletim Informativo, Anexo B).

Situada em frente a um $\mathrm{CEU}^{12}$ e rodeada pelos conjuntos habitacionais, a Casa Ser foi inaugurada em outubro de 2003 graças a uma iniciativa da Coordenadoria da Mulher em parceria com a Secretaria Municipal de Saúde, a Subprefeitura da Cidade Tiradentes, a Companhia de Habitação Popular (COHAB) e o Consulado do Japão. De acordo com a chamado Cartilha Para Profissionais de Saúde, documento datado de 2006 (há algumas páginas da Cartilha no Anexo A), a Casa Ser responde a uma demanda urgente na região, dados os altos índices de mortalidade materna e o alto número de mães adolescentes. $\mathrm{Na}$ época, um quarto das mulheres do local eram chefes de família, únicas responsáveis pelo

\footnotetext{
${ }^{11}$ Disponível em: http://smdu.prefeitura.sp.gov.br/criminalidade/. Acesso em: 23 de fevereiro de 2013. ${ }^{12}$ Centro de Educação Unificado. São várias unidades na cidade de São Paulo, todas localizadas em bairros pobres. $\mathrm{O}$ espaço se destina à educação formal e informal, tem quadras de esportes, piscina, etc.
} 
orçamento doméstico e criação dos filhos. Essas estatísticas colocaram a Cidade Tiradentes como alvo de ações políticas voltadas para as mulheres.

Por meio das informações contidas na Cartilha, é possível perceber que desde o princípio a Casa Ser foi pensada não somente para dar conta das questões de saúde sexual e reprodutiva das mulheres do distrito. É nítido o cuidado da proposta de trabalho quanto à abordagem do gênero como tema transversal e eixo de todas as atividades oferecidas. A Cartilha apresenta, mais que a oferta da Casa Ser, o posicionamento teórico-político da Coordenadoria da Mulher quanto ao trabalho com gênero como articulador de temas, além de referenciais teóricos que desde o princípio estão presentes nas ações e no discurso propagados pela Casa Ser. A própria definição do conceito de gênero utilizada no material é a de Scott (1991) reproduzida numa nota de rodapé na página 9. Além disso, diz-se que é impossível alcançar relações equitativas nem melhorar a qualidade de vida das mulheres sem incorporar os recortes de gênero e raça. Não presenciei nenhuma atividade que trabalhasse intencionalmente com o recorte de raça e, curiosamente, o material não menciona classe como sendo outro recorte relevante, considerando-se as características locais.

Um dos informativos sobre a Casa Ser apresenta uma lista com seus objetivos, bastante amplos, almejados pelas atividades oferecidas. São eles (APÊNDICE B):

- $\quad$ Proporcionar o acolhimento, orientação e reflexão sobre direitos das mulheres, funcionamento do corpo, sexualidade e planejamento reprodutivo;

- Proporcionar acesso às mulheres a todos os métodos contraceptivos e atendimento ginecológico, reforçando o caráter educativo das ações de saúde incorporando o enfoque de gênero;

- Garantir atendimento não preconceituoso às adolescentes grávidas, levando em consideração sua autonomia e sendo reconhecidas como cidadãos de direito;

- Promover com as escolas da Cidade Tiradentes e a Casa Ser, proporcionando um espaço de escuta aos adolescentes e grupos de reflexão, abordando os direitos sexuais e reprodutivos numa perspectiva de raça e gênero. (BOLETIM INFORMATIVO, s.d.).

Sobressaem entre os objetivos sinais da postura adotada ou ao menos idealizada pela instituição, por exemplo, na afirmação "garantir atendimento não preconceituoso", que implica no mínimo uma constatação: as adolescentes grávidas sofrem preconceito. Contudo, não fica claro que tipo de preconceito e nem em que esse atendimento difere de qualquer outro atendimento tradicional.

Outro ponto curioso é que ao afirmar que elas serão reconhecidas como "cidadãos de direito", o substantivo "cidadãos" foi usado no masculino, não concordando com o sujeito 
“adolescentes grávidas". É provável que o termo tenha sido assim flexionado, pois os cidadãos de direito ocupam uma posição mais privilegiada em comparação às adolescentes grávidas, o que sem dúvida estabelece uma relação de poder entre os dois grupos, privilegiando os primeiros. Butler (2003) afirma que algumas correntes do feminismo que partem dos escritos de Simone de Beauvoir argumentam que "a pessoa universal e o gênero masculino se fundem em um só gênero (...), enaltecendo os homens como portadores de uma pessoalidade universal que transcende o corpo" (BUTLER, 2003, p. 28), o que parece ser uma associação bastante cabível no caso acima.

As análises seguintes buscaram seguir a mesma lógica reflexiva empregada acima. Espera-se que explicitem questões, temas e discussões importantes acerca do gênero e de como vem sendo abordado e trabalhado no campo da saúde a partir de uma realidade local específica eleita para sediar esta pesquisa.

\subsection{As entrevistas e as atividades observadas}

\section{A) Planejamento familiar}

Quando as funcionárias mencionaram pela primeira ver a expressão "planejamento", tive certeza de que se tratava do planejamento das atividades semanais ou mensais. Não pensei imediatamente que se tratava de um grupo de discussão sobre planejamento familiar, até por que a palavra "familiar" não complementava a expressão quando dita pelas funcionárias no cotidiano da Casa Ser.

De acordo com a enfermeira Silvia, uma das responsáveis pela condução do grupo, o planejamento familiar é uma atividade obrigatória prevista em lei para as usuárias (mulheres ou casais) que busquem métodos contraceptivos definitivos: a laqueadura ou ligadura de trompas para as mulheres e a vasectomia para os homens. Ao final de dois encontros coletivos, quem decidir pelo método definitivo agendará uma entrevista com a médica ginecologista para marcar a cirurgia. Quem quiser atendimento individual poderá também marcar ao fim dos dois encontros. 
De acordo com informação disponibilizada na página da Saúde ${ }^{13}$, no site do Governo Federal, a Lei do Planejamento Familiar prevê os métodos definitivos de contracepção para pessoas com mais de 25 anos e pelo menos dois filhos vivos, ou nos casos em que há risco de vida para a mulher ou para o futuro bebê. É preciso aguardar 60 dias entre a manifestação da vontade de realizar a cirurgia e sua execução. Por serem considerados métodos irreversíveis de contracepção, é necessário garantir que quem vai se submeter a eles tenha consciência disso e de suas consequências, isto é, da impossibilidade de gerar filhos novamente ${ }^{14}$.

Essa atividade é geralmente coordenada por uma das enfermeiras, acompanhada por uma das assistentes sociais. Algumas das pessoas participantes procuram a Casa espontaneamente, buscando informações sobre métodos contraceptivos ou colocação de DIU (dispositivo intrauterino), por exemplo. Outra parcela das pessoas é encaminhada à atividade pelos recepcionistas, pois procuram a Casa justamente buscando contracepção cirúrgica.

O número de pessoas que participou do grupo variou entre 6 e 7 pessoas e apenas 3 foram homens, junto de suas companheiras. As mulheres, em sua maioria, não estavam acompanhadas. Todas vieram de bairros da zona leste.

Além das participantes estavam presentes a enfermeira (que coordenou a atividade), a assistente social (que passou a lista de presença e apresentou a atividade) e eu (observando a atividade). Isso se repetiu nos três grupos que acompanhei. Os encontros tiveram duração média de 2 horas cada um.

O conteúdo da atividade variou. Um dos grupos foi especificamente planejado para estimular a participação das mulheres membros do Conselho Gestor da Casa Ser que, segundo as funcionárias, há tempos não participava de nenhuma ação. Esse encontro teve como base inicial para as discussões a apresentação de um curta-metragem chamado Acorda Raimundo ${ }^{15}$ que, resumidamente, conta a história de um casal que acorda numa manhã com os papéis de homem e mulher invertidos, ou seja, ela é a provedora que trabalha na oficina mecânica fora de casa e ele é o dono de casa que cuida dos filhos, lava roupas, cozinha e engravida. No desfecho do curta, percebe-se que foi tudo um sonho do personagem masculino, o que o deixa

${ }^{13}$ Disponível em: http://www.brasil.gov.br/sobre/saude/saude-da-mulher/metodos-anticoncepcionais. Acesso em: 23 de fevereiro de 2013.

${ }^{14}$ Apesar de definitivas, as próprias enfermeiras chamam a atenção para o fato de que uma pequena porcentagem de pessoas que as realizaram vieram a gerar filhos posteriormente, provavelmente por uma reversão natural da condição cirúrgica ou pela reversão médica intencional dela.

${ }^{15} \mathrm{O}$ filme, protagonizado por Paulo Betti e Eliane Giardini, na época casados na vida real. Disponível em:

$\mathrm{http}: / /$ www.youtube.com/results?search_query=acorda+raimundo\&oq=acorda+raimundo\&aq=f\&aqi= g3\&aql=\&gs_sm=e\&gs_upl=1901184410121141131121014141112241111112.5.11810. Acesso em: 23 de fevereiro de 2013. 
aliviado. Segue-se uma breve discussão sobre o filme com as participantes e em seguida se inicia a apresentação dos métodos contraceptivos destinados a pessoas do sexo masculino e feminino.

A segunda parte, composta da apresentação dos métodos, foi basicamente o conteúdo total dos 2 outros grupos de planejamento que acompanhei. A forma de apresentação se deu por meio de material didático como ilustrações do corpo feminino em pôsteres e mostruário dos métodos contraceptivos. Todo o material está claramente voltado para a saúde sexual e reprodutiva da mulher.

\section{B) Leitura do Exame Papanicolau}

Esse grupo de discussão se destina a ensinar as mulheres usuárias a lerem e compreenderem o que está escrito em seus exames ginecológicos de Papanicolau sem a ajuda de um médico. A Casa Ser realiza o exame gratuitamente.

No Brasil, o Papanicolau, segundo informações do Instituto Nacional do Câncer (INCA) ${ }^{16}$, deve ser realizado por mulheres que já tenham tido sua primeira relação sexual e que tenham entre 25 e 64 anos, pois é sobre essa população que mais incide o câncer de colo de útero, enfermidade que o exame ajuda a detectar precocemente e assim aumentar a chance de um tratamento bem sucedido. A recomendação brasileira sobre a periodicidade do exame segue a da Organização Mundial de Saúde (OMS): deve ser repetido a cada 3 anos, após 2 primeiros exames consecutivos realizados com espaço de 1 ano entre eles (para reduzir a possibilidade de falso negativo).

O Papanicolau traz informações técnicas sobre a análise do muco coletado da cavidade vaginal que quase sempre são incompreensíveis para as usuárias. Além disso, a frequência com que aparecem termos como "inflamação" e "ferida", usados corriqueiramente, podem gerar preocupações desnecessárias. Sendo assim, a enfermeira Laura reúne as mulheres que receberam seus exames em uma sala e os lê com elas, explicando em linguagem simplificada o que os termos técnicos querem dizer e quais as consequências de alguns dos diagnósticos.

De acordo com a própria Laura, que faz essa afirmação ao abrir o grupo, "a oficina é uma forma de conhecer a própria saúde, de se ter autonomia, por meio da leitura do

\footnotetext{
${ }^{16}$ Informação disponível em: http://www2.inca.gov.br/wps/wcm/connect/acoes_programas/site/home/nobrasil/programa_nacional_c ontrole_cancer_colo_utero/deteccao_precoce. Acesso em: 23 de fevereiro de 2013.
} 
Papanicolau" (Laura). Ela enfatiza também que os conhecimentos que ela compartilha com o grupo são descobertas pessoais, algumas aprendidas em cursos de formação, portanto, não era preciso concordar com ela do ponto de vista da saúde, o que mostra uma intenção de estimular as mulheres a procurarem explicações mais detalhadas sobre seus exames, além da tentativa de relativizar o saber que ela possui: não é a única verdade possível.

Essa atividade é um pouco mais curta que o planejamento familiar, durando cerca de 1 hora. No grupo que acompanhei havia 4 mulheres presentes, uma delas carregando um bebê de colo.

Laura conduziu o grupo sozinha e, fora as participantes, apenas eu estava presente. Ela leu item por item do resultado do exame, explicando cada um dos termos e acompanhando cada participante em sua leitura também, afinal, os exames têm resultados diferentes. Além dos termos, Laura reforça a importância do exame e esclarece sua função.

\section{C) Oficina de Artesanato}

A Casa Ser oferece às usuárias a oportunidade de aprenderem a fazer algum trabalho de artesanato para que possam posteriormente vender e incrementar a renda doméstica. Há oficineiras que oferecem aulas semanais e outras que são convidadas para dar cursos específicos.

A observação foi feita durante uma oficina de bordado em chinelos. As alunas levaram cada uma um par de chinelos de borracha e a oficineira levou as miçangas e o material que seria utilizado para bordar os chinelos.

Entre 7 e 10 mulheres participaram da atividade (muitas entravam e saíam a todo momento), que teve duração longa se comparada às outras atividades da casa, aproximadamente 3 horas. Algumas das participantes eram funcionárias da Casa Ser. Muitas alunas de outros cursos ou ex-alunas apareceram durante a aula para mostrar os trabalhos que passaram a fazer e vender após terem aprendido nas oficinas, como estatuetas de biscuit e bonecas de pano.

Essa atividade não tem a intenção de promover discussões acerca da saúde das mulheres nem sobre gênero, especificamente. Porém, ela por si só tem um caráter de incentivar a independência financeira das participantes por meio da renda obtida com a venda dos artesanatos. Como a renda da maioria das usuárias da Casa Ser é baixa, assim como grande parte da população da Cidade Tiradentes, elas têm dificuldade em vender os chinelos bordados. Uma das participantes, Beth, que auxilia a oficineira a ensinar o bordado, conta-me 
que elas não sabem onde comprar miçangas por um preço mais baixo em locais perto de suas casas e que não podem se deslocar até o centro da cidade por falta de dinheiro. Por isso, a Casa Ser busca oferecer o material. O primeiro chinelo que as alunas bordam é financiado também pela instituição, mas os seguintes precisam ser comprados pelas alunas, pois se subentende que elas já conseguiram vender o primeiro chinelo bordado e gerar alguma renda. Entretanto, é muito difícil vender, já que os compradores igualmente não têm recursos para pagar. Beth me explica essa situação, que registrei após a oficina: "nunca se faz amarras complicadas nos chinelos, pois isso toma muito tempo e depois se tenta vender o chinelo por 30 reais, as pessoas não pagam. Então, ela prioriza amarras mais simples, com menos miçangas." (Registro ampliado).

\section{D) Palestra com o Defensor Público}

Um defensor público foi chamado a dar uma palestra na Casa Ser sobre a Lei Maria da Penha. A intenção era passar às usuárias noções gerais sobre a lei e tirar dúvidas daquelas que tivessem algum processo em tramitação na justiça ou que precisassem de alguma orientação jurídica.

Havia 4 mulheres na sala, entre as quais uma era uma assistente social recém formada, não usuária da Casa Ser, que foi à palestra para se informar melhor sobre a lei.

A parceria da Casa Ser com a Defensoria Pública do Estado de São Paulo é recente e desde então um representante visita a instituição com a finalidade de atender diretamente casos que precisem de intervenção jurídica ou para oferecer palestras sobre temas diversos.

Essa atividade foi especialmente interessante, pois ofereceu uma amostra do pensamento jurídico sobre a questão da violência contra a mulher. Eu fiz poucas anotações, pois o conteúdo exposto era interessante para mim, assim como para as outras usuárias.

O defensor explicou que no caso de um roubo, por exemplo, o processo criminal é automático, pois o Estado e a sociedade se sentem ofendidos pelo crime. No caso da violência contra a mulher, por sua vez, a vítima tem seis meses para representar, isto é, para dar encaminhamento ao processo. Se ela não procede com a representação, o processo é arquivado. Mas por que o Estado não se sentiria ofendido quando uma mulher sofre violência? Fiz essa pergunta ao defensor, ele sorriu e desconversou. Ainda sobre a lei, aponta uma questão que aparece com certa frequência em artigos que tratam da Lei Maria da Penha: 
não é possível saber a que violência essa lei se refere, doméstica, contra a mulher ou de gênero? Ele também não aprofundou esse assunto.

\section{E) Grupo de Discussão com Adolescentes}

O grupo de discussão com as adolescentes se destina a abordar o planejamento familiar e outras questões de sexualidade com o público mais jovem que o presente no grupo do planejamento familiar. O conteúdo é bastante similar entre as duas atividades.

Os grupos são separados por idade, pois se entende que a abordagem dos assuntos com adolescentes deva estar mais focada nas transformações do corpo que se acredita serem típicas desse período.

O grupo observado tinha três mulheres presentes, com idades entre 14 e 21 anos. O material didático utilizado foi o mesmo do planejamento familiar. A condução também foi responsabilidade de uma das enfermeiras, Laura, que não contou com uma das assistentes sociais neste caso. A duração foi de aproximadamente 1 hora.

A abordagem dos métodos contraceptivos pareceu ser mais informal que no grupo para pessoas mais velhas e outros assuntos, que não apareceram naquele grupo, neste foram bastante presentes, como a relativização da importância de casar e ter um marido, da primeira relação sexual, das mudanças do corpo, etc., enfatizando o comportamento em detrimento das questões médicas.

\section{F) As entrevistas}

Além da entrevista realizada com a enfermeira Laura, no primeiro contato com a Casa Ser, uma outra funcionária foi entrevistada, a recepcionista Leila. Ela foi considerada uma informante chave, por ser bastante envolvida nas atividades e por ter participado delas quando iniciou seu trabalho ali. Isso a caracterizava como uma funcionária que poderia falar da Casa Ser também do ponto de vista de usuária do serviço.

Outras entrevistas estavam planejadas, porém, foi sugestão da banca de qualificação que me concentrasse nas atividades observadas e não coletasse mais dados. A entrevista com Leila foi considerada para a análise dos dados, pois traz informações importantes para a compreensão da dinâmica da instituição e sobre como as atividades incidem sobre as usuárias. 


\section{CONCEPÇÕES DE GÊNERO: SOBRE O QUÊ SE ESTÁ FALANDO E COMO?}

Este capítulo buscou apresentar os principais achados desta pesquisa, que serão discutidos com base nas autoras expostas inicialmente e nas ideias de outros autores que ajudaram a dar significado às falas e situações presenciadas na Casa Ser.

Os subitens contemplam os temas que apareceram com maior frequência entre os dados analisados e que foram mais relevantes de acordo com o que se propôs a problematizar. Falas diretas abordando o gênero foram frequentes. Contudo, muitas das concepções de gênero presentes no local foram perceptíveis por meio de falas indiretas, de posturas e de comentários em momentos diversos, o que nos leva a concordar com Portella, ao sinalizar que a questão de gênero nas instituições é algo que não está prioritariamente ligado ao conteúdo do trabalho educativo, mas sim à institucionalização de ações voltadas para a igualdade de gênero, num processo muito mais político que educativo (PORTELLA, 2005).

\subsection{O foco do atendimento}

A ideia presente no período de lançamento do PAISM que, apesar de ter incorporado as discussões sobre gênero, seguiu a via do controle da natalidade por meio do controle do corpo da mulher, é ainda bastante presente no trabalho da Casa Ser, apesar da distância temporal entre o lançamento da política e a inauguração da instituição. Mais do que isso, essa contradição está expressa pela insatisfação com o fato de a Casa Ser estar vinculada à SMS e não receber apoio para realizar atividades com foco em gênero. A coordenadora Rose, por ocasião dos 16 Dias de Ativismo ${ }^{17}$, reclamou da falta de participação de pessoas de outros serviços nas atividades realizadas, além da falta de apoio à divulgação por parte da Coordenadoria da Saúde. Na visão da coordenadora, a SMS está sucateando aos poucos a Casa e quer que ela se torne um centro médico.

Laura também aponta essa questão, ao ressaltar que quando começou a trabalhar na Casa Ser todas as funcionárias passavam por formação em gênero e hoje não mais, desde "a época que também começou, um pouco depois, começou essa questão de virar mais centro médico, uma briga política muito grande, né, uma questão complicada...”(Laura).

\footnotetext{
${ }^{17}$ A Campanha dos 16 dias de ativismo (de 25 de novembro a 10 de dezembro) tem o objetivo de promover o debate e denunciar as várias formas de violência contra as mulheres no mundo.
} 
Esses relatos me levaram a perceber uma tensão constante com relação ao foco das atividades oferecidas. Apesar de desejarem focar as ações em gênero, as funcionárias precisam manter atividades relativas a questões médicas, como a saúde das mulheres, por exemplo. Seria possível introduzir gênero, de maneira crítica, em meio às discussões sobre saúde. Nas atividades que acompanhei essa tentativa foi evidente, porém, muitas vezes, acabou frustrada pelas constantes referências à medicalização do corpo da mulher que reproduz e legitima o discurso médico dominante. Nas vezes em que esse discurso me pareceu mais nítido foram os momentos em que se deram explicações sobre o corpo. Vejamos a seguir.

\subsection{A questão do corpo}

Útero serve pra quê? Pra gerar bebê. Nosso pênis pode chegar a 18 centímetros! (Trechos de diálogo entre facilitadora e participantes, planejamento familiar)

Quando de minha primeira conversa com a equipe, logo no início do trabalho, uma das assistentes sociais, Marta, me esclarece quais as intenções do trabalho de orientação para o planejamento familiar:

Antes de sair, Marta me pede materiais sobre gênero, diz que trabalha ali há dois meses apenas e que nos encontros de planejamento ela fala sobre métodos anticoncepcionais e cirurgias definitivas. Quem quer agendar a cirurgia já pode consultar diretamente a médica, mas que a intenção é que as mulheres não optem pelo método definitivo. (Registro ampliado, reunião com coordenação).

A intenção é que, após passarem pelo planejamento, as pessoas priorizem outro método, não definitivo, para evitarem a geração de filhos. Uma pesquisadora argentina, Cynthia Del Río Fortuna (2009), realizou um estudo etnográfico para acompanhar atividades de orientação para mulheres que queriam fazer a laqueadura. Resguardando-se as particularidades de cada país, há muitas similaridades entre o que ela observou e o que ocorre na Casa Ser. As diretrizes seguidas pelas profissionais envolvidas levam ao forte desaconselhamento do método devido às suas características definitivas. Vejamos um exemplo: 
Planejamento familiar é para decidir se quer ter filhos ou não e quantos. Se vai dar continuidade a ter filhos ou se vai cortar, pensando no futuro, está planejando. Às vezes muda: se queria casal, mas tem dois meninos, continua tentando. O sexo dos filhos faz mudar de opinião.

Alguns homens querem ter filhos depois e é muito difícil. Às vezes dá pra fazer inseminação artificial, se ainda tiver espermatozoides.

Ultimamente, mais de 50\% se arrepende [da cirurgia]. Podem ter relações muito sinceras, gostosas, mas ninguém garante que daqui a cinco anos vão estar juntos... Casa, descasa...

E se acontece alguma catástrofe e ela perder todos os filhos? Pode querer outro filho para apagar a tragédia. (Registro ampliado, enfermeira Geni, planejamento familiar).

Os fatores considerados relevantes para a realização ou não de uma cirurgia definitiva são chamados por Fortuna de fatores de arrependimento (FORTUNA, 2009). De fato, os fatores de arrependimento estão presentes na avaliação que as profissionais fazem sobre a pertinência de métodos definitivos para as mulheres. Não raro, nas atividades acompanhadas por mim, foi comum mulheres cuja situação atendia aos critérios brasileiros para a realização da cirurgia chegarem decididas sobre fazer a laqueadura e ao final do encontro expressarem, ao menos momentaneamente, terem reconsiderado sua decisão. Mais que aos critérios, o teor das discussões nos grupos de planejamento pareceu estar bastante impregnado da crença de que ao perder a capacidade de gerar filhos a mulher perdesse parte daquilo que a define como mulher manifesta pela vontade de ter filhos.

Por outro lado, é papel da equipe técnica advertir sobre a irreversibilidade do método. Ao contrário de outros contraceptivos amplamente difundidos como a camisinha ou a pílula anticoncepcional, as cirurgias parecem resguardadas a casos em que não há outras alternativas. Porém, as mulheres que chegaram às reuniões de planejamento elegendo esse método tinham uma explicação bastante simples e clara: não queriam ter filhos e não queriam se preocupar com outros métodos (colocar o DIU, tomar diariamente um comprimido ou colocar e tirar o diafragma a cada relação sexual). Leila, a funcionária entrevistada, manifestou-se sobre esta questão:

[...] quando a gente participa de um planejamento, eles falam determinado método, aí quando a gente chega lá na frente ou o médico te questiona, ou fica te coagindo a mudar o método, ou quando você escolhe aquele definitivo, você tem que trazer esse e aquele outro pra assinar, aí eu falo assim, eu tenho autonomia sobre o meu corpo, se o corpo é meu, se eu sou 
dona do meu corpo; se eu decidir, por exemplo, operar, por que eu, maior de idade, não posso assinar e acabou? (Leila).

É sabido que a vontade das mulheres de gerar bebês e, consequentemente, exercerem a maternagem é tida como manifestação real da noção essencialista feminina de "instinto materno", segundo a qual todas as mulheres desejariam ser mães e teriam uma habilidade "natural" para cuidar de bebês e protege-los. Entretanto, uma participante do grupo de leitura do Papanicolau nos dá um bom exemplo que desconstrói essa lógica que explica o comportamento das mulheres. Em meio à explanação sobre o que representa no exame o termo "ferida" ${ }^{18}$, a participante conta que havia sofrido um aborto e que o termo havia aparecido recentemente em seu Papanicolau. Inicialmente, ela parece atribuir o aborto à ferida, mas conclui dando uma outra explicação para os fatos:

\footnotetext{
"Fiquei em choque (quando soube da gravidez)! Eu já tenho um bebê de 5 anos, acho que eu coloquei algo em mim, por que eu não podia mesmo, não tem como! Eu soube num dia, no dia seguinte aconteceu o aborto..."

Laura comenta: "Nesse período, provavelmente é uma má formação..."

A participante continua: "o médico falou que eu tenho uma ferida, achei que era isso!"

Há comentários no grupo: "Deus tira" ou "A natureza tira", ao que a participante comenta "É duro... não senti... é duro perder... eu tive meu primeiro filho com 15 anos [...]" (Registro ampliado, leitura do Papanicolau).
}

A sensação que tive - e que expressei no registro ampliado - foi que a participante tentou explicar às demais que foi difícil sofrer o aborto, porém, seu esforço parecia ser de que as outras compreendessem que ela não desejava aquela gravidez, que chegou a desejar não estar grávida, tanto que usou a expressão "acho que eu coloquei algo em mim". Foi isso que, de acordo com sua lógica, fez com que abortasse. Ela se refere a esse "algo" não como alguma coisa material, mas sim um pensamento ruim, uma crença ou algo parecido, que pudesse ter influenciado o aborto. Destaca-se que em nenhum momento há culpa na fala da participante, apenas uma tristeza, uma desolação, porém, a fala pareceu ser de certo alívio pelo fim da gravidez.

\footnotetext{
${ }^{18}$ Segundo Laura, o termo "ferida" no exame do Papanicolau se refere às células granulares, internas, que estão para fora do colo do útero e que por serem mais avermelhadas causam um aspecto de machucado, de ferida. A presença de ferida não significa que haja algum problema, pois essa movimentação de células é normal, mas o termo costuma causar preocupação nas usuárias.
} 
A vontade de cessar a potencial capacidade de ser mãe é geralmente recebida com estranheza, daí a argumentação sobre a irreversibilidade do método frente a tantas outras opções reversíveis, o que é bastante compreensível, visto que as profissionais envolvidas no grupo de planejamento familiar assumem a responsabilidade pela informação das candidatas à cirurgia, podendo ser cobradas depois por qualquer detalhe não esclarecido no momento da decisão.

Cabe ressaltar que quando o caso é de mulheres que já tiveram problemas em partos ou que estão tendo ou tiveram gestações de risco, a tendência da equipe é concordar imediatamente com a opção cirúrgica, vide o conselho da facilitadora a uma das candidatas à laqueadura, grávida, mãe de três filhos, com quase 40 anos e hipertensa: "Se você tiver um novo namorado, arruma um cachorrinho, adota... no seu caso não tem contra indicação." (Registro ampliado, planejamento familiar). De outra forma, a vontade manifesta da usuária de fazer a cirurgia não é suficiente para autorizá-la.

Helena Altmann (2009), ao acompanhar um grupo de educação sexual com jovens, chama a atenção para a ênfase dada à reprodução quando o objetivo da ação é a não concepção, o que revela um paradoxo, presente nas falas e nos livros referentes ao assunto. Resguardadas as particularidades de cada um dos contextos, acredita-se que há similaridades entre o que identificou Altmann e o que acontece na Casa Ser: a finalidade do planejamento familiar parece menos voltada a ajudar as pessoas a decidirem com consciência e responsabilidade sobre o número de filhos, como e quando tê-los, mas sim, e principalmente, a ensinar métodos para evitá-los. Diz Altmann:

[...] quando se fala sobre sexo, toda ênfase recai justamente sobre fecundação, gestação e maternidade. Cabe, portanto, questionar se enfatizar a gestação e vincular reiteradamente a relação sexual à reprodução são as melhores estratégias quando se tem o objetivo de prevenir a gravidez entre jovens. (ALTMANN, 2009, p.191).

De fato, em alguns momentos tive a impressão de que apesar de toda informação dada acerca dos métodos contraceptivos, a gravidez parecia algo mágico, que acontece independentemente do que se possa fazer para evita-la:

Uma participante conta: "Minha prima tá grávida, o marido fez vasectomia há seis anos. Antes era um nozinho ou... não, tirava um pedaço, né? Antes revertia mais fácil", ao que Geni responde "Quando a natureza quer, não tem jeito, né?" 
Geni diz: "Muito raramente acontece da trompa inchar e captar um óvulo. Teve um caso de uma mulher que processou o médico, mas o ultrassom mostrou que a trompa esticou e captou um óvulo. Às vezes você tá devendo um filho aí pro mundo, né? Pode acontecer, tá na sua cota [...]." (Registro ampliado, planejamento familiar).

Em ambos, pela explicação da facilitadora, é algo acima da vontade das pessoas envolvidas que determinou a gravidez. Essa força maior pode ser a natureza ou, no segundo caso, uma missão, uma "cota" imposta à mulher que estaria "devendo" um filho ao mundo, já que seu papel prioritário é ser mãe. Contraditoriamente, essas falas aparecem quando se discute justamente o controle que o casal pode ter sobre a geração de filhos, o planejamento da família. Ora, se há forças maiores que impõem filhos ao casal, então para que prevenir a gravidez?

Marilyn Strathern (1995), autora inglesa, ao discorrer sobre uma polêmica gerada pelas mães que queriam "bebês, mas não o sexo" (STRATHERN, 1995, p. 303), por meio de fertilização in vitro, traz elementos chave para compreender a intencionalidade de se tratar o par relação sexual - reprodução como inseparáveis. Para ela, o sexo simboliza o relacionamento entre os pais de um futuro bebê, o desejo que sentem um pelo outro e que, consequentemente, sentirão sobre ter filhos:

Dai a importância do desejo da futura mãe e daí a noção euro-americana da própria concepção, pois o esforço humano se aplica em fazer o relacionamento que fará o filho. Isso e tão importante que se acredita que tudo o que se segue depois acontece automaticamente. $\mathrm{O}$ crescimento e eventual aparecimento do filho são encarados como uma questão de processo biológico que segue seu próprio caminho. $\mathrm{O}$ aparecimento do filho é inevitável (excetuando-se um acidente) e a forma que adquire simplesmente demonstra a união original de gametas na relação genética. (STRATHERN, 1995, p. 327, grifos originais).

A inseparabilidade entre relação sexual e fecundação é bastante menos enfatizada no grupo de adolescentes. As três mulheres presentes não tinham filhos e participavam da atividade para aprender sobre os métodos contraceptivos. A facilitadora, Laura, tentou desmistificar algumas crenças, o que pode ser observado nos trechos abaixo:

Laura diz: "Pensar em sexo interfere no estudo? Se ficar grávida sim, mas pode sexo seguro". 
E continua: "Dá pra você escolher um método? Engravidar quando quiser? Tem que tomar decisão de modo consciente. A Casa está aqui pra isso". (Registro ampliado, grupo de adolescentes).

Além de ressaltar o papel da Casa Ser na orientação para o exercício saudável da sexualidade, há uma tentativa de não colocar o sexo no lugar do que é errado e proibido, desde que feito com responsabilidade e consciência. Não está presente o discurso do medo, que liga de forma mágica qualquer relação sexual à consequente gravidez, tão presente no outro grupo.

Outro momento curioso, que também apareceu durante o planejamento familiar, foi a discussão sobre os aparelhos reprodutores. A facilitadora, Silvia, estimulou o debate fazendo perguntas às participantes e, a partir de suas respostas, deu explicações. $\mathrm{O}$ trecho a seguir relata a situação:

Silvia pergunta: "Útero serve pra que?". A resposta de uma participante: "Pra gerar bebê." Silvia complementa "No ovário se produz óvulos. Tem muita diferença entre o homem e a mulher? Sim. Mas isto nos torna diferentes? Não. A mama da mulher se desenvolve para que?", participantes: "Para amamentar.".

Silvia: "Qual o aparelho reprodutivo dos homens?". Participantes: "Testículos?", Silvia explica: "Os testículos são cheios de espermatozoide, servem para a proteção das células do homem. No calor, aumenta, e no inverno, diminui. A bexiga não aparece no desenho do corpo da mulher, mas sim no do homem, por que ela faz parte do sistema reprodutivo dele. Para que serve o pênis?", participantes: "Para penetrar"; "Para fazer xixi".

Silvia: "Por isso o homem não consegue transar se estiver de bexiga cheia, a mulher pode fazer xixi enquanto transa. $\mathrm{O}$ homem tem o orgasmo pelo pênis, a mulher pelo clitóris, que é feito do mesmo tecido que o pênis. Vocês sabiam que nós também temos nosso pênis? Nosso pênis pode chegar a 18 centímetros!".

Participante: "Ah, então é por isso que tem mulher que é sapatão!?”, Silvia: "Não, isso é outra coisa... O clitóris quanto é tocado fica inchado, incha tudo por dentro. Não é fechado, é aberto por dentro. É mais rico de tecidos do que o pênis do homem. Depois de ejacular, o homem precisa parar. A mulher, quando termina, pode continuar. O clitóris é como um 'pênis embutido'. Onde é nossa fonte de prazer? No clitóris. Para que a vagina serve?", Participantes: "Pra saída de menstruação"; "Por onde sai o bebê no parto normal"; "Para penetração". (Registro ampliado, planejamento familiar).

O trecho acima apresenta muitos pontos interessantes. De forma geral, o que chama a atenção é que apesar das respostas dadas pelas participantes, não houve nenhuma tentativa, nem da facilitadora, nem das participantes, de estimular a discussão para que ela tomasse outro rumo. Não houve questionamentos à função do útero, à do pênis, ao comentário da participante sobre o tamanho do clitóris definir a identidade de gênero de alguém e nem à 
afirmação de que a mulher tem pênis. Todas essas situações, entre outras, teriam sido oportunidades para se questionar a validade dessas informações, o quanto estão impregnadas de um discurso médico acrescido de crenças e conhecimentos populares que ajudam a reforçar pensamentos acerca dos sexos e da sexualidade que se objetivava, de acordo com o que sempre foi dito sobre a finalidade das atividades, desconstruir.

O corpo feminino foi exclusivamente associado à sua função reprodutiva: a vagina é por onde sai a menstruação e os bebês, o útero é onde se geram os bebês e as mamas se desenvolvem para amamentar. A associação da vagina à relação sexual ocorre somente na última resposta e mesmo assim com conotação passiva, isto é, a que recebe a penetração. $\mathrm{O}$ pênis, por outro lado, é associado diretamente à penetração, acompanhada da função fisiológica de "fazer xixi”. Destaca-se que apesar de ter sido rapidamente associado à penetração, a ejaculação não foi sequer lembrada, o que não atribui ao homem qualquer papel na geração dos bebês. Lembrando que se tratava de uma oficina de planejamento familiar, seria importante ressaltar o papel do homem, seja na contracepção, seja na geração dos filhos e seu cuidado. No entanto, a atenção da facilitadora pareceu estar restrita quase que somente às informações sobre a mulher.

Parece haver uma tentativa de Silvia em valorizar as características da mulher em detrimento às dos homens. Ao falar sobre o orgasmo, ela recorre a uma comparação curiosa para explicar o clitóris, definindo-o como o pênis da mulher, feito do mesmo tecido que o pênis do homem e podendo alcançar o tamanho de 18 centímetros. O interessante aqui é que se emprega um tipo de eufemismo: para aumentar a importância do clitóris ela o compara ao membro masculino, como se a genitália feminina precisasse ser parecida à masculina para ter algum valor, para que ambos estejam equiparados em termos do prazer que podem proporcionar.

Antes de prosseguir com esse exemplo, há uma questão relevante a se considerar aqui acerca do conhecimento que as participantes tinham com relação aos corpos feminino e masculino. Compreende-se perfeitamente que as facilitadoras precisassem aludir a uma linguagem mais simples e informal para explicar algumas questões mais delicadas, como uma parte do corpo que se considera íntima. De modo contrário, o conteúdo poderia causar desconforto entre as usuárias ou mesmo incompreensão devido ao uso de termos mais técnicos. Entretanto, no caso em questão, há outros recursos de que se poderia lançar mão para qualificar o corpo da mulher. A vagina, os seios e o clitóris são importantes por serem considerados zonas erógenas e fonte de prazer para muitas mulheres e o incentivo para que conheçam seu próprio corpo e obtenham prazer com isso ainda é muito desigual quando 
comparado ao incentivo que recebem os homens. Eles são estimulados desde crianças a mexer no pênis, a exibi-lo, etc., e a menina não raro é reprimida quando tem o mesmo comportamento. Em outras palavras, o clitóris, assim como a vagina e os seios, são importantes por si só e não por que tem características em comum com um pênis. Mesmo as outras "vantagens" da mulher foram todas apresentadas em comparação às características masculinas: ela não precisa interromper a relação sexual como o homem depois do orgasmo e o clitóris é mais rico em tecidos que o pênis.

Em outro momento, Silvia estimula as mulheres a conhecerem melhor o próprio corpo e genitais. Ela diz: “Antes eles eram mais feios, hoje são mais bonitos... ela [a vagina] é nossa, faz parte do corpo. É bom olhar com espelhinho... todo dia se olha no espelho, tem que olhar ela, cuidar dela. Os nomes para o pênis demonstram poder, diferente dos nomes para a vagina." (F). Apesar de perceber uma diferença de poder, a saída encontrada para equiparar homens e mulheres acabou por legitimar o maior poder dos homens, reafirmando a verdade que se pretendia desconstruir.

Ainda que não se possa afirmar se por reconhecer a evolução da sexualidade feminina ou por outros fatores, Silvia diz que os genitais hoje "são mais bonitos". Realmente, uma grande parcela das mulheres se sente mais livre hoje para se tocar e conhecer seu corpo do que suas companheiras de décadas passadas. Porém, não se pode negar que se convive hoje em dia com um mercado voltado à estética do sexo, que engloba desde tipos de depilação, medicamentos como o Viagra $^{19}$ até cirurgias para redução dos lábios vaginais. Essa estética, comercializada como mercadoria, acaba por produzir "mais necessidade dela mesma, por que se criam novos padrões" (informação verbal ${ }^{20}$ ). Essa questão fica clara quando Silvia utiliza um painel com o desenho do corpo de uma mulher nua que tem pelos pubianos. Ela pergunta, mostrando o cartaz às participantes: "Vocês são assim?" ao que uma delas responde "Não com esses pelos todos!", provocando risos generalizados. O corpo sem pelos, artificialmente criado, parece ter sido naturalizado e acabou virando um padrão para a participante.

Outra afirmação interessante: "O homem tem o orgasmo pelo pênis, a mulher pelo clitóris". Desconsidera-se que homens e mulheres têm orgasmos das mais variadas formas, não somente pela estimulação de certas partes do corpo. Há ainda os que não têm orgasmo. A afirmação parece estar amparada por algumas correntes da sexologia, que há tempos ditam,

\footnotetext{
${ }^{19}$ O Viagra foi o medicamento pioneiro no tratamento da disfunção erétil. Os comprimidos de cor azul são amplamente conhecidos e utilizados no mundo inteiro.

${ }^{20}$ Informação fornecida pela Profa. Dra. Jane Russo em seminário sobre a Medicalização da Sexualidade na Faculdade de Filosofia, Ciências e Letras da Universidade de São Paulo, em novembro de 2012.
} 
normatizam a relação sexual e a forma de obtenção de prazer. Essa sexologia data da década de 1920 e, com base no trabalho de Kinsey $^{21}$ sobre a função do orgasmo, teria ajudado a coloca-lo como problema central dos estudos sobre sexualidade (ROHDEN; RUSSO, 2011). Daí os primórdios da prática de tentar determinar a forma correta de se obter orgasmo, por meio da estimulação das partes corretas do corpo.

Um último ponto que merece atenção foi o comentário de uma das participantes que associa o tamanho do clitóris à identidade de gênero de uma mulher. A fala da facilitadora, que afirma que o "pênis da mulher" (o clitóris) pode alcançar o tamanho de 18 centímetros parece confundir e acaba gerando uma indagação na participante, que pergunta: "Ah, então é por isso que tem mulher que é sapatão!?”. Ora, se a mulher tem um pênis, então ela se aproximaria mais de um homem que de uma mulher. Portanto, seu objeto de desejo seria também uma mulher e se assume que tal pessoa seria "sapatão". A escolha do termo "sapatão" (em vez de lésbica ou gay) é cheia de significado, neste caso, pois muitas vezes é empregado para se referir às lésbicas mais masculinizadas. Se a pessoa tem um pênis, então é homem. Neste caso, como a figura em questão era uma mulher e como não existe mulher com pênis, então ela tem que ser "sapatão".

É interessante como a participante busca estabelecer uma coerência diante da afirmação da facilitadora. A questão da coerência é tema frequente no trabalho de Butler (2003). Ela argumenta que a coerência e a continuidade "não são características lógicas ou analíticas da condição de pessoa, mas, ao contrário, normas de inteligibilidade socialmente instituídas e mantidas" (BUTLER, 2003, p.38). Uma vez que haja descontinuidade entre os conceitos estabilizadores de sexo, gênero e sexualidade, como na figura da mulher com pênis, a própria noção de pessoa é abalada. Ela também argumenta que, paradoxalmente, a descontinuidade e a incoerência só são concebíveis em relação “às próprias leis que tentam estabelecer linhas causais ou expressivas de ligação entre o sexo biológico, o gênero culturalmente constituído e a 'expressão' ou 'efeito' de ambos na manifestação do desejo sexual por meio da prática sexual” (BUTLER, 2003, p.38). Em outras palavras, só há padrão em relação ao que está fora da norma e o que é anormal só é definido em com base na norma.

\footnotetext{
${ }^{21}$ Alfred Kinsey foi um pesquisador da sexualidade humana, fundador do hoje chamado Instituto Kinsey para Pesquisa sobre Sexo, Gênero e Reprodução.
} 


\subsection{Participação dos homens}

Vou me reter ao aparelho reprodutor.

(Silvia)

Vamos falar da vasectomia rapidinho.

(Geni)

Em todos os momentos que acompanhei na Casa Ser o conteúdo estava voltado às mulheres, mesmo naqueles em que havia homens presentes. Apesar de o trabalho da instituição estar desde o nome direcionado às mulheres, é importante considerar que os temas trabalhados dizem respeito tanto a elas quanto a eles. O próprio planejamento familiar implica decisões tomadas pelo casal, mas a presença masculina não parece ser estimulada nem atraída.

É frequente certo incômodo com a presença masculina em espaços como a Casa Ser. A ênfase na independência e emancipação da mulher parece implicar necessariamente o desprezo pelos homens, como se esse fosse um passo a ser dado em benefício da mulher. Além disso, parte-se do pressuposto de que os homens não são usuários da atenção primária em saúde, então o ambiente não é preparado para recebê-los (GOMES et al., 2011, NASCIMENTO; CARRARA, 2012). Lembro-me de uma situação pessoal, quando trabalhei em um centro de atendimento a mulheres vítimas de violência doméstica, em que os companheiros ou ex-companheiros das usuárias deixavam de ser chamados pelo nome, passando a ser denominados genericamente por "agressor". Em uma situação específica, determinou-se que homens não poderiam entrar no local nem para acompanhar suas companheiras em atendimento.

Essa prática merece ser questionada. Se o que se almeja é a concretização da equidade de gênero, então seria desejável que o maior número de pessoas possível participasse ativamente das atividades de um centro que se propõe a discutir as desigualdades, sejam mulheres ou homens.

Arriscar-se-ia dizer que esse discurso tem origens na teoria do patriarcado, segundo a qual:

[...] a divisão de trabalho baseada no sexo implicou desigualdade ou opressão sexual apenas no momento em que surgiram as classes sociais baseadas na propriedade privada. As formas da opressão sexual, tais como as formas de parentesco e a família, teriam uma base material na estrutura de classes. A opressão das mulheres, assim como a exploração de classe, poderiam ser superadas através da instauração de uma forma de organização 
social mais desenvolvida, numa sociedade sem classes, por exemplo, no socialismo. (PISCITELLI, 2002, p. 9).

Essa visão, ao longo da história, levou à compreensão de que as mulheres sempre estiveram em desvantagem com relação aos homens, independentemente do contexto. Essa ideia percorre algumas das falas:

O que eu entendo é que a desigualdade existe, na questão de que o homem está sempre a frente de tudo, e a frente de tudo nas melhores coisas, e na frente de tudo no poder, de mandar, a mulher está sempre atrás, em ter que obedecer, ter que aceitar e hoje, graças a Deus isso está mudando. Eu acho que é trabalho de formiguinha, mas eu acho que está mudando por que hoje as mulheres têm autonomia para algumas coisas, elas podem dizer "faço isso", "não faço aquilo", "não quero fazer aquilo" [...]. (Leila)

Ele [o defensor público] comenta a seguir sobre a sociedade ainda ser patriarcal, com o homem ocupando posições privilegiadas sempre, reproduzindo a sociedade europeia. Diz que está havendo, aos poucos, uma mudança de visão. (Registro ampliado, palestra do defensor público).

São desigualdades de gênero (apontando para mim). São características do masculino e do feminino - a mulher fica em desvantagem, sai perdendo. (Registro ampliado, planejamento familiar).

Apesar de assumirem que existem mudanças acontecendo, todos compreendem a sociedade como se os homens estivessem a frente de tudo, as mulheres atrás deles. A noção da opressão feminina universal tem sido amplamente questionada por outras correntes do feminismo que vieram a partir da década de 1970, para as quais a dominância masculina não se aplica a grupos primitivos com que trabalhou a antropologia tradicionalmente, pois seu mundo não estava organizado em termos de domínios de poder (PISCITELLI, 2002). Afirmase também que homens e mulheres sofrem as consequências das normas rígidas de gênero, estando em vantagem ou desvantagem dependendo da situação, do contexto, do momento histórico, etc. Na educação brasileira, por exemplo, as mulheres estão em vantagem com relação aos homens, que abandonam a escola mais cedo e são tidos como piores alunos que elas (CARVALHO, 2007; ROSEMBERG, 2002). No que se refere à manifestação de carinho, as mulheres também estão em vantagem, pois podem se expressar com maior liberdade sem serem questionadas acerca de sua sexualidade ou identidade de gênero.

A Casa Ser é um espaço feminino, dentro dos moldes tradicionais da atenção primária à saúde, que é um espaço majoritária e historicamente feminino no Brasil (GOMES et al., 2011, NASCIMENTO; CARRARA, 2012). Todas as atividades que acompanhei foram 
direcionadas às mulheres. Os homens presentes eram apenas acompanhantes e sobre eles e as especificidades de seus corpos, pouco foi dito. As epígrafes no início deste item refletem a intenção das facilitadoras em trabalhar o conteúdo acerca dos homens. Enquanto sobre as mulheres se abordaram características físicas, psicológicas e sociais, sobre eles se resignou à explicação do aparelho reprodutor e sobre como é a cirurgia de vasectomia, porém, "rapidinho" - realmente a exposição foi muito breve -, pois havia mais conteúdo a ser dito sobre a mulher ou por que sobre eles não se sabe muita coisa.

Os homens estavam presentes em dois dos grupos e, ao longo de aproximadas 2 horas de duração, entravam e saíam da sala a todo o instante, provavelmente desinteressados e sem compreender tantos detalhes sobre o corpo feminino ou, o que é bem provável, constrangidos diante de um tema delicado para quem, diferentemente da mulher que é instruída a frequentar o ginecologista desde a primeira relação sexual, não precisa se expor à avaliação médica desde a adolescência.

Um desses homens acompanhou sua esposa no planejamento, pois o casal precisava decidir entre fazer a vasectomia ou a laqueadura. A mulher estava grávida de oito meses e alegava que queria parto normal. Sendo assim, não faria a laqueadura logo após o parto, pois não haveria cirurgia. Ela alegava que o marido deveria fazer a vasectomia, pois ambos, além do que estava para nascer, já tinham filhos de outros casamentos e não queriam mais. $\mathrm{O}$ marido, por outro lado, nas duas reuniões de que obrigatoriamente participou (lembrando que é obrigatório passar pelo planejamento e aguardar 60 dias entre a decisão pelo método definitivo e a cirurgia), passou o tempo inteiro reivindicando que era a esposa que deveria fazer a laqueadura. $\mathrm{O}$ homem tinha medo de que a cirurgia fosse amputar uma parte de seu corpo ou o deixar com alguma disfunção. Para acalmá-lo, a facilitadora Geni, após retomar a explicação sobre os canais que levam os espermatozoides e o líquido seminal ao pênis, inicia o diálogo abaixo:

Geni diz: "Vamos falar da vasectomia rapidinho (...). O médico corta o canal, dois pontinhos e o camarada vai embora, anestesia local."

A mulher diz: "É um cortinho? Ele acha que vai cortar!", diz isso rindo, fazendo um sinal que indica que ele acha que vão cortar seu pênis.

Ele diz: "Amor, você vai fazer, eu não preciso.".

(...) Geni: "Os homens têm medo, mas o que faz o pênis ficar duro é o sangue e o cérebro. Não tem a ver se vai ter espermatozoide ou não.".

Ela diz: Tá vendo, amor [...]. (Registro ampliado, planejamento familiar).

O homem teve seu medo exposto a um grupo majoritariamente feminino, o que provocou risos em todos: achar que a vasectomia era um tipo de castração. Por mais 
divulgada que essa cirurgia possa ser, ela ainda provoca esse tipo de sentimento em alguns homens, seja por falta absoluta de informação, seja por uma crença de que ao perder a fertilidade, o homem perdesse também um pouco de sua masculinidade. Associação similar foi feita anteriormente, com relação à laqueadura, o que mostra que, de modos diferentes, homens e mulheres precisam lidar com certas expectativas relativas a seus papéis sociais de pai e de mãe.

Apesar de enfatizar que a cirurgia não corresponde à castração e que também não provocará nenhuma disfunção erétil, a facilitadora, momentos antes, ao explicar o aparelho reprodutor masculino, dá destaque justamente ao processo da ereção peniana:

Geni diz: "O pênis endurece por algum estímulo visual, lembrança, vontade de fazer xixi, etc. É uma coisa fisiológica: pensou, o cérebro estimula, o pênis fica duro. O homem brocha ou é só o vizinho? Na maioria das vezes é emocional." (Relato ampliado).

Por outro lado, a explicação sobre a excitação feminina foi a seguinte:

Geni continua: "O período mais fértil da mulher é quando tem muco, maior lubrificação, tá mais sensível, mais a fim, mais excitada!" (...)

Participante: "É quando o marido tá mais bonito!" e Geni complementa: “A comida está melhor, tem até sobremesa!" (Registro ampliado).

Percebe-se uma diferença de enfoque entre os dois trechos. A ereção é descrita como um processo meramente fisiológico deflagrado por uma estimulação cerebral. A excitação feminina, por sua vez, é descrita em termos de maior disponibilidade para a relação sexual, seja por que a mulher fica "mais a fim" ou por que o "marido tá mais bonito". A complementação de Geni pode ser entendida de duas maneiras: ou a percepção da mulher fica mais aguçada e ela, da mesma forma que vê o marido mais bonito que usualmente, sente melhor o sabor dos alimentos, ou a excitação aumentaria a disposição da mulher para as tarefas domésticas, então ela faz uma comida mais saborosa e até inclui sobremesa.

As pesquisadoras Rohden \& Russo se depararam com a seguinte realidade ao buscar identificar concepções de gênero e sexualidade no campo das intervenções terapêuticas em torno do sexo:

Enquanto a sexualidade masculina é definida pela lógica do desempenho, medido pela ereção e tratado com medicamentos e técnicas que resolvam o problema específico da disfunção erétil, a sexualidade feminina é apresentada como um fenômeno complexo e intrigante, não redutível a uma 
função orgânica específica. (...) A sexualidade masculina é, "naturalmente" pensada como independente da relação com parceiras, um impulso autônomo, incontrolável, independente de relações ou afetos. A mulher continua sendo vista como um ser eminentemente "relacional". Sua sexualidade não existe como impulso autônomo, separado da conjugalidade (ou das relações). (ROHDEN; RUSSO, 2011, p. 728).

As diferenças de gênero estão sendo enfatizadas a partir da sexualidade, o que ajuda a compor um paradoxo: como incentivar a emancipação da mulher, que conheça e seja dona de seu próprio corpo, se a ela ainda ficam restritas as funções de vetor dos afetos e esteio da conjugalidade, conferindo-lhe um papel passivo? Mais ainda, como é possível envolver e sensibilizar os homens para a causa da mulher se o que compete a eles está restrito ao campo do desempenho sexual? São questões pertinentes a se considerar quando se pensa no tipo de sujeitos que se pretende formar com tais atividades.

\subsection{Formas de resistência}

Dentre as ousadas tentativas da equipe da Casa Ser em questionar conhecimentos tidos como verdadeiros, certamente se destaca uma maneira de certa forma transgressora de tratar o campo médico. Esse fator chama a atenção, pois parece ser simbolicamente a expressão da resistência de uma instituição que deseja manter sua origem marcada pelo movimento feminista frente à pressão para que se torne um centro de serviços médicos. Essa resistência está presente nos excertos abaixo:

"Como saber se o método [contraceptivo] é bom pra você?" e a participante responde: "O médico!", ao que Laura retruca: "Será? Só a gente decide qual é o melhor método!" (Registro ampliado, grupo de adolescentes).

O método é uma escolha individual, depende do que se tem de valor por trás. (Registro ampliado, Geni, planejamento familiar).

No exame dá tudo, somos parte de um todo maior ainda. A alteração de células no exame pode ter a ver com tudo. O médico vê o corpo, o físico. (Registro ampliado, Laura, leitura do Papanicolau).

O médico jamais vai enxergar... não tem $\operatorname{CID}^{22}$ de questão espiritual, o médico não vê mentalmente... O PSF era pra isso, para ver no nível corporal geral da família, da comunidade, etc., mas não acontece. (Registro ampliado, Laura, leitura do Papanicolau).

\footnotetext{
${ }^{22}$ Classificação Estatística Internacional de Doenças e Problemas Relacionados à Saúde (CID).
} 
Há desigualdade entre homem e mulher. A mulher, começou a ter relação sexual, tem que passar no ginecologista. Ele tem que saber tudo de mim. Somos acostumadas a isso. Precisamos conhecer o corpo e os métodos para poder escolher e propor para o ginecologista. (Registro ampliado, Silvia, planejamento familiar).

Muita gente acha que aqui tem que dar, que garantia de gênero é dar acesso às mulheres para ginecologia, pra, por aqui, não pelo sistema, se a pessoa não consegue fora, então dá um jeito de resolver por aqui dentro, mas não! A gente tá no meio do sistema né! (Laura).

A resistência é perceptível nesses relatos devido ao incentivo à não submissão do corpo ao médico e aos conhecimentos médicos. A medicina tem sua pretensa superioridade desqualificada e sua eficácia relativizada, já que se diz que ela não é capaz de englobar questões para além do físico e do corpo, como a espiritual e a mental. Há inclusive uma ironia à prática médica de categorizar as doenças e diagnosticá-las por manuais e códigos: não há CID para tudo.

No volume I da História da Sexualidade, Foucault faz uma série de proposições sobre as relações de poder, "correlações de força desequilibradas, heterogêneas, instáveis e tensas" (FOUCAULT, 1988, p.104). Ele afirma que esse conjunto de forças se forma e atua nos aparelhos de produção, famílias e instituições formando uma linha de força geral que atravessa os afrontamentos e os liga entre si. Afirma também que "lá onde há poder, há resistência" (Idem, 1988, p.105), que não é exterior ao poder, mas intrínseca a ele. A resistência assume o papel de adversário, de apoio, mas não de fragilidade em relação ao poder, representando, um tipo de interlocutor irredutível que se configura em uma situação particular.

O que se pode observar por meio dos dados coletados é justamente a coexistência de discursos representados por forças contraditórias que compõem a Casa Ser, que revelam também um certo tipo de resistência que brota do contexto específico no qual está inserida e do qual faz parte. Não se trata de um discurso radical, mas sim de um posicionamento sutil que emerge em momentos específicos e que revela o desejo de grande parte da equipe envolvida nas atividades. Apesar de não totalmente militante nem combativa, essa atitude questionadora pode mobilizar reflexões e transformações significativas para as usuárias. Reproduzindo as palavras do próprio Foucault, 
Grandes rupturas radicais, divisões binárias e maciças? Às vezes. É mais comum, entretanto, serem pontos de resistência móveis e transitórios, que introduzem na sociedade clivagens que se deslocam, rompem unidades e suscitam reagrupamentos, percorrem os próprios indivíduos, recortando-os e os remodelando, traçando neles, em seus corpos e almas, regiões irredutíveis. (FOUCAULT, 1988, p.107).

A postura assumida em relação ao conhecimento médico pode, assim, levar os sujeitos a compreenderem outros pontos de vista, que também estão validados por um discurso, o discurso da Casa Ser. Durante a entrevista com Laura, perguntei se ela havia observado mudanças nas usuárias após passarem pelas atividades oferecidas. Laura contou sobre uma senhora que veio acompanhar a filha no planejamento familiar e acabou compartilhando que estava insatisfeita com a relação que tinha com o marido, que a forçava a ter relações sexuais com ele do jeito que ele impunha. Após passar pelas discussões no grupo de planejamento, ao início do segundo encontro, ela contou que havia preparado a ocasião, com jantar, luz de velas, lingerie e disse ao marido que naquele dia as coisas seriam como ela desejava. Laura diz que se surpreendeu, pois a senhora havia permanecido calada durante o primeiro encontro, mas que aquilo havia causado nela uma enorme transformação, legitimada pela Casa Ser. Laura me conta:

Ele foi jogar ela no sofá, ela "Não, não, é você quem vai deitar, hoje eu vou te comer!" Uma senhorinha de idade de repente falar que ela queria dividir com as pessoas de uma conversa que a gente teve que ela ficou quietinha... Ela tinha resolvido mudar a relação dela com o marido, mudar a postura na sexualidade, porque ela sentiu que ela tinha... na verdade ela sentiu que a gente que deu autorização, até aí, né... (...) Mas ela se sentiu autorizada de uma certa forma, né... (Laura).

A senhora conseguiu mudar a situação porque se sentiu autorizada por um discurso, algo que legitimou sua atitude de mudar de postura em relação ao marido. Sem dúvida, esse tipo de conquista é louvável e demonstra o que pode ser alcançado pela via do jogo de forças e da resistência.

Além do posicionamento quando se trata do conhecimento médico, há outros momentos de significativa resistência - das funcionárias e das usuárias - quando se trata dos comportamentos esperados para homens e mulheres. Em varias situações, fez-se presente um estímulo, uma aprovação de performances que não condizem com as expectativas sociais normalmente reconhecidas para os gêneros. Vejamos alguns exemplos: 
Depois do filme, Marta conduz uma discussão sobre ele. As mulheres comentam: "Os homens não se colocam no lugar da mulher, acham que têm razão"; "Minha amiga acha que tem que chegar antes em casa para deixar tudo pronto, casa limpa, comida e bebê pronto". (Registro ampliado, participantes, planejamento familiar).

Silvia complementa: "O marido sempre ajuda em casa; a responsabilidade é da mulher e o marido vai ajudar. A família é dos dois, tem que ter divisão das tarefas. Ajudar é diferente de participar, de companheirismo. No filme ${ }^{23}$, ele pode bater nela. Ele pode ficar no bar e ela não. A sociedade ensinou que homem pode bater na mulher por que é mais forte. A mulher passou a trabalhar, a sociedade colocou isso e nós fomos reproduzindo. A mulher quando trabalha pode querer benefícios para ela própria ou ela quer o salário do marido na mão, mas por que, se é parte da família? Por que não fazer o orçamento e gastar junto? (Registro ampliado, Silvia, planejamento familiar).

A mulher dá e recebe. Não tem 'perder a virgindade'. Não perde, e sim, ganha nova vida sexual. A gente pensa que só o homem recebe [...]. (Registro ampliado, Silvia, planejamento familiar).

Se eu não me incomodo com os papéis da sociedade, a gente vai reproduzir no futuro. (Registro ampliado, Silvia, planejamento familiar).

[...] as pessoas pensam de uma única maneira: que mulher tem que casar, ter filhos, cuidar da casa, cuidar do marido, que mulher não pode sair para trabalhar fora, mulher não pode separar, mulher não pode... tem que aguentar ali, a gente vê cada caso de violência que a mulher continua, continua, ah, é por que eu casei, por que ele paga minhas contas, sabe essas coisas? (Leila).

Além da resistência, está clara a ideia de que os comportamentos são aprendidos e reproduzidos e, por isso mesmo, podem mudar. Há um chamado para que as usuárias não reproduzam, não repitam as mesmas tradições e contribuam para uma sociedade diferente.

As maiores expressões de resistência e indignação apareceram na entrevista com a funcionária Leila. Ela, que participou de várias das atividades junto com as usuárias quando iniciou seu trabalho na Casa Ser, revela um alto grau de insatisfação pela constante sensação de estar sendo julgada por suas escolhas. Para ela, assumir o papel feminino nos moldes tradicionais constitui um fardo:

Então, o meu convívio ainda é assim, entendeu? E parece que numa época passada, quando eu não conhecia a Casa eu pensava assim: é tudo distorcido, não é tecnicamente falando como estar na sociedade, brigando, os

\footnotetext{
${ }^{23}$ Ela se refere ao filme “Acorda Raimundo!”.
} 
movimentos, as questões, ativismo, aquela questão toda, então assim, eu acho que eles estão muito a frente, estão preparados, e a gente fica sempre assim, eu ficava assim pensando, puxa, será que eu estou totalmente errada, ou será que, sei lá o que acontece comigo, por que eu tinha uma visão diferente das coisas e das pessoas. Então, quando eu comentava certos assuntos, as pessoas falavam assim... olham assim pra mim, tipo, ai nossa, sabe... eu falo assim por uma questão de você conhecer um homem, e vc quer e vc vai ali... eu ia ali, na luta, tal, então a outra pessoa olha assim, tipo, que será que tá acontecendo, a pessoa eu acho que não é legal, tipo, o que será que está acontecendo, né, ela parece que tem problema de cabeça, entende? (Leila).

Além de expressar seu descontentamento com a forma como as pessoas a compreendem, Leila se manifesta positivamente sobre o papel que a Casa Ser teve em sua vida. Parece que a aproximação com a instituição a possibilitou conhecer gente que pensava como ela, que a compreendia e a deixou à vontade para que ela pudesse viver sua vida como desejasse. Novamente, percebe-se a importância que a Casa Ser tem na legitimação e aprovação de atitudes que suas usuárias e funcionárias tomam diante de fatos cotidianos e das pessoas e, nesse sentido, entende-se o valor de se manter o espaço como prioritariamente feminino, como se isso favorecesse uma certa relação de confiança entre as mulheres que ali frequentam.

Leila também menciona como considera importante a educação dos filhos, para que eles não reproduzam e tenham as mesmas atitudes de que ela tanto reclama:

Por mais que quando você tiver seus filhos você for educar eles dizendo que ele tem que respeitar, por que ele pode ser... pode ter a individualidade dele, né, a orientação dele ser tal, não ser igual à de todo mundo, né, por mais que vc fale que seu filho enquanto homem tem que ajudar nas tarefas domesticas, que ele não vai deixar de ser homem por isso(...) então, por mais que vc faça isso, certo, seu filho vai dar valor, vai continuar homem, né, ah, "eu vou cozinhar pra minha mãe e eu vou continuar homem", por mais que vc faça isso, quando ele estiver lá na frente, lá fora, ele vai se deparar com situações diferentes... daquela mãe que educou que o filho homem não pode fazer tal coisa por que ele é homem. E da menina fazer tal coisa, não fazer tal coisa por que ela é mulher, né. Então eu fico pensando, poxa, será que um dia a gente vai estar falando na mesma língua, todo mundo agindo da mesma maneira, todo mundo respeitando todo mundo, todas as diferenças, né... que não tem só de gênero, né, tem um monte, né. Aí eu fico aqui pensando, puxa... e chego até assim a desanimar... mas tem pessoas que estão vivendo em prol disso, outras questionam, brigam, vão atrás, né, dão a cara a tapa... ainda bem, né? (Leila).

Leila faz uma separação bastante clara entre o movimento organizado (de mulheres, LGBTTT e outros) e sua postura individual, que ela entende como sendo transgressora, que 
choca as pessoas, mas que não teria o mesmo efeito. O que pode estar evidenciado por essa separação é a compreensão de que apenas o movimento organizado tem um papel educativo efetivo na sociedade, como se a transformação que ela almeja dependesse não da ação política de cada um, mas de uma mudança radical daqueles que se dedicam e militam. Em outro momento, quando perguntei a ela o que aconteceu para que ela tivesse uma postura diferente na vida e o que achava que precisaria ser feito para que as pessoas também mudassem, ela chega a assumir e a reconhecer sua atitude como algo que pode motivar reflexões e mudanças:

Teve uma época que eu achava que as pessoas pra trabalhar na Casaser ou pra trabalhar neste tipo de serviço deviam passar por uma capacitação, viver aquilo e fazer aquilo. A gente tem uma fala que vc já deve ter ouvido da sua mãe, do seu pai, "a gente prega o que a gente vive". Então assim, pra eu pregar o que eu vivo, é lógico que tem gente que prega coisas diferentes, que no dia a dia não tá vendo, sofre com isso. Tipo assim, eu falo algumas coisas que a outra pessoa não aceitou, não fala, mas eu sofro por isso, tem empecilhos no caminho, não é fácil, né? E também não é fácil pra mim ouvir... não é fácil pra pessoa escutar e pra mim também não é fácil escutar o que as pessoas falam, às vezes, me incomoda, ou então eu amenizo, conforme a opinião dela eu sei que me incomoda, eu sei que a minha também vai incomodar, mas eu acho que todo mundo que passa por aqui, que trabalha aqui teria que passar por uma capacitação, trabalhar naquilo, pregar aquilo e viver aquilo, que aí eu acho que seria... o trabalho desenvolveria melhor, teria mais produtividade, por que tem muita gente que faz, mas não vive, e quando fala não fala de uma maneira que eu vou te convencer ou que eu vá te levar a refletir, pelo menos. Eu acho que capacitação sempre tem, sei lá, não sei se um curso mudaria a pessoa, mas assim, passaria por um curso, capacitação e experiência, pra poder ver se a pessoa na prática é mesmo, por que na teoria todo mundo faz tudo, todo mundo entende tudo, só que na prática não, né... é diferente. (Leila, grifos meus).

Leila valoriza a coerência entre o que se fala e o que se faz, entre teoria e prática. Para garantir isso, defende que exista uma capacitação para as pessoas que vão trabalhar em locais como a Casa Ser, como se uma formação fosse a garantia do compromisso com a causa e da mudança de postura. Esse tema já foi problematizado por Portella, 2005, que afirma que a formação, apesar de preciosa e fundamental, é apenas um elemento de um processo de construção que é muito mais político que educativo, o que configuraria um limite central na formação de profissionais de saúde.

A questão da formação das profissionais que trabalham na Casa Ser já teve outro status quando dos anos iniciais de funcionamento. As duas funcionárias entrevistadas, Laura e Leila, apontam a formação inicial como um marco de mudança, como o momento em que identificaram que havia pares que pensavam como elas. Laura comenta: 
Por que na realidade eu vinha fazendo essas conversas, né, mas sem... Sem esse conceito de gênero. Achando que devia ser alguma coisa assim, mas sem entender muito bem, mas eu acabei vindo pra cá e foi aqui que eu comecei "ah, então isso é assim", "é por isso", sabe, aí consegue dar nome pras coisas [...]. (Laura).

Como já foi mencionado anteriormente, a formação em gênero está cada vez mais sucateada devido à intenção de que a Casa Ser se transforme em um centro médico. As próprias funcionárias assumem que há discordâncias entre elas quanto às ideias fundamentais sobre gênero e que nas capacitações que foram propostas, as pessoas não participavam:

Então, a gente tava fazendo um programa pra formação do funcionário dentro dessa questão toda que a gente trabalha. Só que... Não vem! A gente marcou... Horário de manhã, à tarde, pra que todo mundo tivesse chance de fazer... (...) A gente também tava tentando fazer umas atividades, ia pegar os filmes que tem, ia ver os filmes, ia começar a aparecer essas discussões também. Por que tem muita gente que não viu esses filmes que a gente usa todo dia! E... Só que quem tá participando: são só três pessoas que tá participando nesses cursos, que poderia tá formando... (...) mas não tem muita abertura das pessoas de discutir essa questão de gênero não, os pensamentos são muito diferentes. Quando essa gerente chegou aqui ela fez uma reunião pra entender o que cada um achava que aqui devia ser (...) o que é que vocês entendem pelo programa. Por que como perdeu o caminho, né, vamos ver o que as pessoas daqui estão achando que deve ser, por se não, as pessoas começam a boicotar [...].

Laura expõe uma questão importante que influencia o bom andamento das atividades da Casa Ser. Como se pode perceber, o desenvolvimento das atividades pode estar comprometido por que as pessoas que as coordenam não passaram por nenhuma formação específica para conduzir as discussões disparadas pelos filmes exibidos ou por outro recurso utilizado. Esse é um ponto crucial para que as atividades cumpram seu papel de promover reflexões válidas sobre gênero, equidade e emancipação, contribuindo para a resistência e não engrossando o discurso generalista.

Como a Casa Ser é primeiramente um centro de atenção à saúde, havia uma pessoa responsável pelo atendimento médico. Esse profissional mudou durante os anos de investigação. Na primeira entrevista, Laura contou que o médico que realizava o atendimento ginecológico tinha uma compreensão do trabalho bastante tradicional, o que parecia ser um entrave para garantir a coerência entre as diferentes frentes de trabalho da Casa Ser. Quando retornei, no ano seguinte, a profissional responsável era uma médica, cujo trabalho não foi mencionado em nenhuma de minhas observações ou entrevistas. A única referência que se fez 
à profissional foi ao final dos encontros sobre planejamento familiar, pois as participantes eram encaminhadas a ela caso desejassem realizar cirurgias contraceptivas (laqueadura ou vasectomia). Também não me foi sinalizada nenhuma importância em consultar essa profissional nas conversas frequentes que tive com Laura e Rose. Ademais, nunca vi a médica circulando pela Casa Ser como as outras funcionárias. Ela ficava dentro de sua sala (onde também não entrei) aguardando as usuárias que atendia rápida e sucessivamente. Como seu trabalho era por plantão, pode ser que coincidentemente não tenhamos comparecido nos mesmos dias e por isso não tenhamos nos encontrado.

Apesar de não contar com a opinião da médica para oferecer alguma interpretação para esse fato curioso, ele é um dado significativo. Parece que ela ocupava um status diferenciado em comparação com as enfermeiras, assistentes sociais e outras profissionais do centro, sendo chamada pelas colegas de "doutora" e não pelo nome, como se chamavam entre si. Entretanto, apesar do aparente respeito pela posição ocupada por ela e da maioria das atividades contarem com conteúdo educativo claramente médico, a participação da médica na condução dessas atividades foi sempre dispensada, o que também pode significar, em alguma medida, uma forma de resistência.

\subsection{Falando diretamente sobre gênero}

Apesar de gênero ser um termo presente nos documentos da Casa Ser, as funcionárias o mencionaram diretamente muito provavelmente por que eu, ao me apresentar, dizia que esse era o foco de minha pesquisa. Em outros momentos, nos grupos, quando surgia algum assunto que provocava a discussão sobre o tema, as facilitadoras olhavam para mim, chamando minha atenção. Nas entrevistas, perguntei diretamente sobre concepções e conceitos de gênero norteadores do trabalho da Casa Ser e alguns comentários muito interessantes apareceram:

[...] acho que a questão de gênero está envolvida em todos os ciclos da vida da gente, no que a gente está vivendo, na escola, faculdade, até quando começa desde a primeira idade, desde o prezinho, na creche e vai indo na faculdade, no trabalho, então acho que a gente vai indo nesse conflito a gente vai vendo e vai vivendo todas as etapas e acho que em tudo da vida da gente [...]. (Leila).

Então, eu não sei definir o que é gênero. A única coisa que eu sei do que é gênero é a diferença que existe, a desigualdade que existe entre o homem e a mulher, por eu ser mulher e por ele ser homem.(Leila, grifos meus). 
(...) começa a diferença de gênero lá na infância... por que a menina põe a mão, já fala "ah, nhém, nhém, não põe a mão, isso é feio, não sei o que....". O menino põe a mão, às vezes até a mãe mesmo faz uma fala que deixa o menino todo, todo... se sentindo, né? A menina não, tudo errado, isso é feio [...]. (Leila).

Dos papéis a e da construção social, né, dos papéis de poder de homem e mulher e da construção social [...]. (Laura).

Nenhuma das concepções se refere somente à mulher. Elas parecem estar mais centradas nas diferenças e desigualdades entre homens e mulheres e aparece também como um "conflito". Está presente a compreensão de que gênero é uma construção que se relaciona aos papéis e ao poder.

Há uma sentença muito interessante em uma das falas de Leila (em destaque). Nota-se que, diferentemente de outros momentos, desta vez ela não desqualifica a mulher em relação ao homem, mas apenas localiza a origem da desigualdade na oposição entre homem e mulher. O significado é construído por meio do contraste, em que uma definição positiva se apoia na negação ou repressão de algo antiético a ela (SCOTT, 2000). O estabelecimento de uma oposição fixa oculta a interdependência entre os opostos, isto é, que um não existe sem o outro. Oculta também o que têm de semelhante.

O que Leila vê em seu meio, em seu trabalho e em seu convívio social são as manifestações de uma cultura que estabeleceu barreiras de gênero intransponíveis, baseadas em diferenças, cuja origem se perdeu ao longo dos anos e hoje se tenta resgatar por meio de explicações hormonais, cerebrais, genéticas, psicológicas e tantas outras. Em vez de se centrar nas semelhanças, reforçam-se as diferenças.

Laura também se remete às diferenças. Ela menciona os papéis sociais designados para homens e mulheres e o poder implicado no desempenho de um papel ou outro. É importante ressaltar que ela não naturaliza as diferenças e os papéis assumidos, mas os admite enquanto "construção social". Ainda que esteja se referindo apenas ao gênero como construção (e não ao sexo), esse reconhecimento é bastante válido, pois, toda construção pode ser redefinida.

Como já foi destacado anteriormente, tanto Laura quanto Leila, apesar de diferentes formações e trajetórias, profissões e funções dentro da instituição, assumem que suas ideias e concepções acerca do gênero se formaram nas situações que vivenciaram ao longo da vida, mas foram consolidadas na Casa Ser, nos momentos de formação. Esse é um dado importante sobre os efeitos do envolvimento das pessoas com o trabalho da instituição. 
A Casa Ser está entre os Centros de Referência ligados à Secretaria Municipal de Saúde, contudo, sua idealização e concretização estão muito mais associadas à Coordenadoria da Mulher (CM), organismo do governo criado em 1989, que busca dar coerência às políticas municipais do ponto de vista do gênero. De maneira específica, a Coordenadoria é responsável por elaborar e acompanhar o desenvolvimento das políticas públicas dirigidas às mulheres do município de São Paulo.

O alvo da atuação da CM são as mulheres, e isso delimita o espectro de possibilidades embutidas no tema gênero. Assim como a agenda internacional dos grandes eventos de direitos humanos, gênero está sendo tomado praticamente como sinônimo de mulher.

De acordo com Piscitelli (2001) gênero foi incorporado ao discurso político na tentativa de incluir as ideias pós-estruturalistas acerca da opressão das mulheres. De acordo com essa corrente, a teoria do patriarcado resultou insuficiente e inadequada para retratar mulheres que viviam situações, contexto e momento histórico específicos, centrando-se no que as mulheres tinham em comum e não nas diferenças entre elas. As teóricas pósestruturalistas promoveram uma revolução teórica no campo feminista e fizeram emergir uma teoria alternativa ao patriarcado, centrada nas diferenças. No entanto, ela acabou por enfraquecer o movimento de mulheres, que precisava de um grupo delimitado e com reivindicações comuns para ter seus objetivos concretizados. Apoiando-se em Nicholson (2000), Piscitelli vê como uma saída o resgate da categoria mulher, porém, esvaziada de qualquer origem fundamentada na essência da mulher. Pelo contrário, essa nova categoria mulher favoreceria "políticas de coalizão, compostas de listas de reivindicações relativas às diferentes necessidades dos grupos que constituem, temporariamente, a coalizão" (PISCITELLI, 2001). Isto permitiria uma prática feminista destinada a transformar os discursos por meio dos quais as mulheres, em situações específicas, estão subordinadas e em desvantagem. Desvantagem, por exemplo, de mulheres pobres em relação às mulheres ricas, de mulheres negras em relação a mulheres brancas, de mulheres em relação aos homens, de funcionárias em relação a seus chefes, entre outras tantas possibilidades. Scott (2000) também defende uma prática política que transcenda a divisão binária e incorpore a diversidade para a conquista de bens comuns, porém, reivindicados por grupos transitórios e não fixos.

Não é possível afirmar com base nos dados analisados como a categoria mulher está sendo compreendida na Casa Ser. Se fosse, provavelmente me depararia com compreensões diferentes e divergentes que compõem a heterogeneidade de forças e discursos que perpassam a instituição. Apesar de constar da Cartilha para Profissionais a definição de gênero de Scott (1985), não é possível saber até que ponto esse conceito foi compreendido, digerido e está 
sendo reproduzido pelas funcionárias nas atividades cotidianas, pressupondo-se que a Cartilha é o material de leitura básico que as funcionárias devem ter como referência.

Mesmo assim, fica latente a presença de um desejo de emancipação pela via do fortalecimento do grupo de mulheres que passa pela Casa Ser. Essas mulheres têm barreiras específicas para transpor como a pobreza, a vulnerabilidade social, a baixa empregabilidade, o preconceito racial entre outros, característicos da população da Cidade Tiradentes. Além desses aspectos mais ou menos comuns entre as usuárias, todas elas buscaram o serviço da Casa Ser por questões particulares, desde o encaminhamento para a realização de um exame passando pelo desejo de aprender sobre a Lei Maria da Penha até a decisão por realizar uma cirurgia contraceptiva. Elas apresentam questões comuns, mas provavelmente encontram caminhos diferentes para a emancipação (inclusive não querer se emancipar) e a Casa Ser parece ser um fator importante de orientação no caminho percorrido por elas.

A questão da utilização do termo gênero em substituição à categoria mulher não é particular dessa instituição. A própria agenda internacional dos direitos humanos ao incluir gênero, refere-se às mulheres. A Organização das Nações Unidas (ONU) tem uma instância específica, a ONU Mulheres ou UNIFEM (Entidade das Nações Unidas para a Igualdade de Gênero e o Empoderamento das Mulheres) ${ }^{24}$, criada para acelerar o atendimento das demandas de mulheres e meninas em todo o mundo. Os Objetivos do Milênio (ODM $)^{25}$, estabelecidos pela ONU com base nos maiores problemas mundiais, apresenta desafios a serem solucionados por todos os países até 2015. O objetivo número 3 se refere à promoção da igualdade entre os sexos e a valorização da mulher ${ }^{26}$. Na descrição do objetivo se reconhece que as mulheres estudam mais que os homens, mas que ainda possuem menores salários que homens na mesma função e ocupam os piores postos de trabalho, o que justifica a intencionalidade das ações com esse público. Os objetivos não incluem, por exemplo, um trabalho intencional para reverter a condição de vulnerabilidade que provoca a morte de milhares de meninos nas periferias das grandes cidades. Também não inclui nada a respeito da grande quantidade de meninos que abandonam a escola antes de completar a educação básica. Tampouco inclui qualquer menção ao grupo LGBTTT, que computa uma amarga série de violações aos seus direitos de cidadãos. Essas também não seriam questões de gênero relevantes? É claro que há instâncias nos organismos internacionais tratando dos interesses

\footnotetext{
${ }^{24}$ Disponível em: http://www.unifem.org.br/. Acesso em: 13 de fevereiro de 2013.

${ }^{25}$ Os Objetivos do Milênio são conhecidos no Brasil também como Oito Jeitos de Mudar o Mundo.

${ }^{26}$ Disponível em http://www.objetivosdomilenio.org.br/. Acesso em: 13 de fevereiro de 2013.
} 
desses grupos, porém, eles não aparecem entre as prioridades no nível global. Internacionalmente, a prioridade segue sendo a mulher. 


\section{CONCLUSÕES}

Esta dissertação buscou identificar e analisar as concepções de gênero presentes na Casa Ser, um centro de atenção à saúde sexual e reprodutiva das mulheres, localizado na zona leste da cidade de São Paulo. Para alcançar esse objetivo, foi construído um percurso teórico que apresentou as principais autoras que deram suporte à discussão realizada, Scott (1988, 1995 e 2000) e Butler (2002, 2003 e 2009). Essas autoras problematizaram o conceito de gênero compreendendo-o como histórico e mutável, questionando a categoria "mulheres" e propondo sua utilização não para denominar um grupo homogêneo com aspirações comuns, mas um grupo de pessoas que podem ter interesses pontuais convergentes. Tais grupos não seriam necessariamente marcados pela submissão feminina ao longo dos tempos, mas poderiam sim lutar pelos direitos das mulheres nas situações em que elas estiverem em desvantagem.

Buscando contextualizar o local da pesquisa, apresentou-se um breve histórico que localiza os estudos de gênero no campo da saúde e traça a trajetória das ações voltadas às mulheres desde o PAISM, por meio do controle de seus corpos. A Casa Ser pareceu seguir a tradição dessa política pública de atenção à mulher, inclusive focando seu atendimento nesse público.

O caminho percorrido até a chegada à Casa Ser foi longo e garantiu uma boa receptividade à pesquisa e à minha presença como observadora durante a realização das atividades. A instituição é um espaço aberto a estudos e parece estar disposto a aprender com visitantes.

As concepções de gênero foram obtidas por meio de observação participante e entrevistas realizadas na sede da Casa Ser. Todo o material coletado se mostrou muito rico mediante o que se pretendia discutir e possibilitou desenvolver a discussão no sentido que se intencionava. Os dados foram organizados em categorias correspondentes aos pontos mais relevantes e significativos para a discussão sobre as concepções de gênero. As minhas percepções acerca das situações presenciadas foram também consideradas na medida em que contribuíram para adensar as análises.

Entre os principais achados, esta pesquisa mostrou que a Casa Ser promoveu importantes reflexões na vida das mulheres que se envolveram em sua dinâmica. Seja entre as usuárias ou entre as funcionárias, notou-se que a participação nas atividades reforçou ou mudou ideias relevantes acerca das relações de gênero, mais especificamente sobre a condição 
da mulher e sua emancipação. Talvez um estudo longitudinal pudesse determinar em que medida o envolvimento de um grupo de pessoas com atividades que abordem o gênero promove ou não a diminuição das iniquidades de gênero ao longo de um período de tempo dentro desse mesmo grupo. $\mathrm{O}$ estudo apresentado aqui, não teve essa pretensão, contudo, talvez se possa inferir por meio dele em que medida as atividades com as quais as mulheres se envolveram mobilizaram transformações em suas vidas decorrentes de terem entrado em contato com conhecimentos acerca do gênero e sobre como ele influencia e constitui o modo se ser das pessoas. De acordo com a fala das entrevistadas, está claro que os conteúdos trabalhados pela Casa Ser estimularam sua autonomia e as fortaleceram para que assumissem uma postura de questionamento diante das regras e imposições decorrentes de hierarquias rígidas de gênero. Porém, quando se analisa os conteúdos trabalhados nas atividades, não é possível saber que tipos de reflexão esses conteúdos estão promovendo no nível pessoal. Sabe-se que o discurso da Casa Ser pode ser significativo ao legitimar ações de resistência, por exemplo, mas ele também pode ser significativo ao reforçar ideias que estão na base da manutenção das mesmas hierarquias rígidas de gênero. Nesse sentido, a participação das mulheres usuárias da Casa Ser nas atividades colaborou para a superação das injustas relações de gênero às quais estão submetidas ou seu envolvimento acabou por reforçar velhos dilemas?

Também se pode perceber que ao abordar gênero a Casa Ser, na grande maioria das vezes, está se referindo à mulher. As mulheres são o alvo das ações desenvolvidas e este direcionamento está marcado desde sua fundação, em 2003. Os esforços para a abertura do local partiram da Coordenadoria da Mulher, órgão em São Paulo responsável pela garantia da inclusão das questões das mulheres nas políticas públicas. Tal intenção foi associada a uma demanda local por atendimento específico a esse público, dados a alta taxa de mortalidade materna e o grande número de mulheres chefes de família, únicas responsáveis pelo sustento do lar. Curiosa e provavelmente decorrente do interesse do financiador principal da Casa Ser, o Consulado do Japão, a instituição nasce como um centro médico e não como um centro profissionalizante ou educativo para mulheres, vinculado à Secretaria Municipal de Saúde (SMS) e não à Coordenadoria da Mulher.

Há um dilema explicitado entre os dados coletados que é decorrente dos fatos mencionados acima e que figura entre os achados deste estudo. Há o desejo de que a Casa Ser possa acompanhar a agenda da Coordenadoria da Mulher, o que quer dizer que receberia recursos para atividades com foco em gênero e não somente para campanhas de saúde. A insistência da equipe em manter as atividades de discussão para além das questões da saúde implica falta de recursos para divulgação de ações como os 16 dias de ativismo (campanha 
voltada ao fim da violência contra as mulheres), dificuldade de contratação de pessoal especializado que possa dar palestras ou apoiar a formação contínua da equipe (processo que já aconteceu, porém foi paralisado) e até a continuidade das atividades de formação com alunos das escolas do bairro, para as quais as funcionárias não têm tempo suficiente. Isso se deve ao fato de a SMS não priorizar esse tipo de pauta em sua agenda. Se fossem realizados, esses momentos poderiam promover reflexões importantes sobre gênero com públicos diversos e certamente - se seguissem o caminho que segue a Casa Ser - contribuiriam para a diminuição da desigualdade de gênero e para a construção de sujeitos mais críticos com relação ao tema.

Em termos da compreensão sobre gênero e sexo, as atividades da Casa Ser são marcadas pela lógica binária, ou seja, pela divisão do mundo entre homens e mulheres. As atividades acompanhadas apresentaram os corpos de maneira dividida, cada um com suas características específicas e muito mais detalhadamente se detiveram ao corpo da mulher que ao do homem. Estes, por sinal, não parecem ser tão bem acolhidos na instituição, não de maneira intencional, mas talvez por falta de conhecimento sobre eles, falta de material didático para abordar temas de seu interesse e, principalmente, porque eles historicamente não têm sido alvo das ações de atenção primária à saúde.

Os corpos foram abordados mais em suas características fisiológicas e houve momentos em que a comparação do corpo da mulher ao corpo dos homens foi a alternativa para atribuir algum valor ao corpo das mulheres, como no caso da referencia ao clitóris como "pênis feminino". Estas também foram apresentadas como mais afetivas e disponíveis que eles. Este ponto explicita uma possível contradição, considerando-se o objetivo de tais atividades conduzidas pela Casa Ser. Se o que se pretende é promover a emancipação da mulher, valorizá-la por meio da comparação de seu corpo com o corpo dos homens e a posicionar como mais afetiva e disponível em comparação a eles parece levar a reflexões opostas às que se pretendia gerar inicialmente. Determinar que a mulher é mais frágil tomando como base explicações fisiológicas e hormonais corrobora o discurso médico dominante, que desde muito tempo tenta justificar a permanência da mulher em sua posição de mãe e cuidadora dentro da família. Novamente, a questão apresentada inicialmente retorna: que tipos de reflexões se têm buscado promover?

Há ainda o desestímulo à realização de cirurgias contraceptivas definitivas e, aparentemente, de acordo com algumas falas, esse desestímulo está relacionado à ideia de que resiste sempre nas mulheres um desejo de ser mãe, independentemente de sua manifestação 
explicitamente contraria a isso. Este dado parece também ir na mesma direção da discussão apontada anteriormente.

Os momentos que denotaram uma posição de resistência chamam bastante a atenção entre os dados obtidos. Apesar de algumas vezes engrossar o discurso médico dominante, a Casa Ser se mantém contrária a algumas ideias bastante comuns sobre o corpo e sobre a submissão desse corpo ao conhecimento médico. É notória a tentativa de chamar a atenção das mulheres para o fato de que só elas podem saber sobre si e não um ginecologista; que podem exercer sua sexualidade de maneira saudável e que isso não necessariamente interferirá em seus estudos ou outros âmbitos da vida. Esse é um avanço significativo em termos da construção nas usuárias de uma percepção de mundo mais consciente e crítica.

Percebe-se também a consciência de que o desenvolvimento de um trabalho comprometido com a transformação das relações desiguais de gênero exige uma transformação pessoal, que nem sempre pode ser mobilizada por uma formação ou qualquer outro processo educativo. Mesmo considerando suas histórias pessoais como fundamentais para a estruturação de suas concepções de gênero, as duas funcionárias entrevistadas atribuíram aos momentos de formação de equipe na Casa Ser a conquista de um lugar que legitimou suas ideias e posicionamentos na vida, o que demonstra uma corrente de confiança e fortalecimento criada entre as mulheres que poderia ser potencializada se houvesse mais investimento para a formação contínua das funcionárias.

Este dilema vivenciado na Casa Ser parece estar relacionado ao fato de que, ao menos no campo dos direitos humanos, gênero ainda é tido como sinônimo de mulher. As pautas dos grandes encontros internacionais, suas agendas políticas e as prioridades determinadas pela ONU estão focadas em resolver principalmente os problemas que afetam as mulheres, numa visão que soa ainda muito próxima à explicação do patriarcado para sua submissão universal. Onde entram outros públicos afetados pelas desigualdades de gênero? Onde entra a garantia da discussão sobre gênero em atividades educativas que favoreçam a construção de sujeitos mais críticos e conscientes sobre sua condição? Como promover atividades que trabalhem a construção do conhecimento sobre os corpos, a construção de sexo e do gênero de maneira que formem sujeitos mais livres? Essas são questões mobilizadas por esta investigação e que poderão ser abordadas futuramente em outros estudos. 


\section{REFERÊNCIAS}

ALtMANN, H. Orientação sexual em uma escola: recortes de corpos e de gênero. Cad. Pagu [online]. 2003, n.21, pp. 281-315. ISSN 0104-8333.

ALTMANN, H. \& MARTINS, C. J. Educação Sexual: ética, liberdade e autonomia. Educ. rev. [online]. 2009, n.35, pp. 63-80. ISSN 0104-4060.

ALVES, H. P da F., ALVES, C. D, PEREIRA, M. N. \& MONTEIRO, A. M. V. Dinâmicas de urbanização na hiperperiferia da metrópole de São Paulo: análise dos processos de expansão urbana e das situações de vulnerabilidade socioambiental em escala intraurbana. Rev. bras. estud. popul. [online]. 2010, vol.27, n.1, pp. 141-159. ISSN 01023098 .

AQUINO, E. M. L., BARBOSA, R. M., HEILBORN, M. L. \& BERQUO, E. Gênero, sexualidade e saúde reprodutiva: a constituição de um novo campo na Saúde Coletiva. Cad. Saúde Pública [online]. 2003, vol.19, suppl.2, pp. S198-S199. ISSN 0102-311X.

AQUINO___ Desafios e limites no ensino de gênero em saúde coletiva: a experiência do MUSA. In: VILLELA W. \& MONTEIRO S. (orgs.) Gênero e Saúde: programa saúde da família em questão. Rio de Janeiro, Abrasco. Brasília, UNFPA, 2005.

BLEGER, J. A entrevista psicológica e seu emprego no diagnóstico e na investigação. In: Temas de Psicologia. São Paulo: Martins Fontes, 1980.

BRASIL. Lei n. 11.340. 7 ago 2006. Cria mecanismos para coibir a violência doméstica e familiar contra a mulher, nos termos do $\S 8^{0}$ do art. 226 da Constituição Federal, da Convenção sobre a Eliminação de Todas as Formas de Discriminação contra as Mulheres e da Convenção Interamericana para Prevenir, Punir e Erradicar a Violência contra a Mulher; dispõe sobre a criação dos Juizados de Violência Doméstica e Familiar contra a Mulher; altera o Código de Processo Penal, o Código Penal e a Lei de Execução Penal; e dá outras providências. Brasília, 7 de agosto de 2006; $185^{\circ}$ da Independência e $118^{0}$ da República.

BUTLER, J. Cuerpos que importan: sobre los límites materiales y discursivos del "sexo". Buenos Aires, Paidós, 2002.

Desdiagnosticando o gênero. Tradução de André Rios. Physis [online]. 2009, vol.19, n.1, PP.95-126. ISSN 0103-7331. 
Problemas de Gênero: feminismo e subversão da identidade. Rio de Janeiro, Civilização Brasileira, 2003. Publicado originalmente em 1990.

CARRARA, S., RUSSO, J. A. \& FARO, L. A política de atenção à saúde do homem no Brasil: os paradoxos da medicalização do corpo masculino. Physis [online]. 2009, vol.19, n.3, pp. 659-678. ISSN 0103-7331.

CENTRO DE ATENÇÃO À SAÚDE SEXUAL E REPRODUTIVA MARIA AUXILIADORA LARA BARCELLOS. Uma outra forma de Atender: Saúde, direitos sexuais reprodutivos. Cartilha para Profissionais de Saúde. Coordenadoria da Mulher, 2006.

CARVALHO, M. P. de. Avaliação escolar, gênero e raça. Campinas/SP, Papirus, 2009.

Desempenho escolar, Gênero e raça: desafios teóricos de uma pesquisa. In:

PAIXÃ O, L.P. \& ZAGO, N. (orgs) Sociologia da Educação; pesquisa e realidade brasileira. Vozes. Petrópolis, 2007.

. No coração da sala de aula: Gênero e trabalho docente nas séries iniciais. São Paulo: Xamã/FAPESP, 1999.

CASARIN, M. R. \& PICCOLI, J. C. E.. Educação em saúde para prevenção do câncer de colo do útero em mulheres do município de Santo Ângelo/RS. Ciênc. saúde coletiva [online]. 2011, vol.16, n.9, pp. 3925-3932. ISSN 1413-8123.

COELHO, E. A. C.. Gênero, saúde e enfermagem. Rev. bras. enferm. [online]. 2005, vol.58, n.3, pp. 345-348. ISSN 0034-7167.

CORRÊA, S. "Saúde reprodutiva”, gênero e sexualidade: legitimação e novas interrogações. In: GIFFIN K.; COSTA S. H. (orgs) Questões da saúde reprodutiva. Rio de Janeiro: Editora Fiocruz, 1999.

COSTA, AS. M. Desenvolvimento e implantação do PAISM no Brasil. In: GIFFIN K.;

COSTA S. H. (orgs) Questões da saúde reprodutiva. Rio de Janeiro: Editora Fiocruz, 1999.

DANTES, M. A. M. Uma ciência da diferença: sexo e gênero na medicina da mulher. Cad. Pagu [online]. 2002, n.19, pp. 319-322. ISSN 0104-8333.

DEBERT, G. G., GREGORI, M. F.. Violência e gênero: novas propostas, velhos dilemas. Rev. bras. Ci. Soc. [online]. 2008, vol.23, n.66, pp. 165-185. ISSN 0102-6909. 
DEL RIO FORTUNA, C. Elecciones en anticoncepción quirúrgica: una mirada sobre la relación entre la técnica y la persona. Runa [online]. 2009, vol.30, n.1, pp. 79-95. ISSN $1851-9628$.

DINIZ, D. \& GUERRIERO, I. C. Z. Ética na pesquisa social: desafios ao modelo biomédico. RECIIS [online]. Dezembro de 2008, v.2, Sup.1, p.Sup.78-Sup.90. ISSN 1981-6278.

EZPELETA, J. ROCKWELL, E. Pesquisa participante. São Paulo, Ed. Cortez, 1989.

FAUSTO-STERling, A. Dualismos em duelo. Cad. Pagu [online]. 2002, n.17-18, pp. 9-79. ISSN 0104-8333.

FORMIGA FILHO, J. F. N. Políticas de saúde reprodutiva no Brasil: uma análise do PAISM. In: GALVÃO L.; DÍAZ J. (orgs). Saúde sexual e reprodutiva no Brasil. São Paulo:

Hucitec. Population Council, 1999.

FOUCAULT, M. Conferência 1. A verdade e as formas jurídicas. Nau Editora/PUC Rio, Rio de Janeiro, p.7-27, 2005.

História da Sexualidade I: A vontade de saber. Rio de Janeiro, Edições Graal, 1988.

O que é a crítica? Cadernos da FFC [online], v.9, n.1, 2000. Faculdade de Filosofia e Ciências, UNESP Marília.

FUNDAÇÃO PERSEU ABRAMO. Pesquisa mulheres brasileiras e gênero nos espaços público e privado. Disponível em

http://www.fpabramo.org.br/sites/default/files/pesquisaintegra.pdf. Acesso em 20 jan. 2012.

GALVÃO L.; DÍAZ J. (orgs). Saúde sexual e reprodutiva no Brasil. São Paulo: Hucitec. Population Council, 1999.

GIFFIN K.; COSTA S. H. (orgs) Questões da saúde reprodutiva. Rio de Janeiro: Editora Fiocruz, 1999.

GOMES, R. et al. Os homens não vêm! Ausência e/ou invisibilidade masculina na atenção primária. Ciênc. saúde coletiva [online]. 2011, vol.16, suppl.1, pp. 983-992. ISSN 14138123. 
HARAWAY, D. Saberes Localizados: a questão da ciência para o feminismo e o privilégio da perspectiva parcial. Cadernos Pagu, v.5, p.7-41, 1995.

HOCHOROVISKY, R. R. e MEIRELLES, G. Problematizando o conceito de empoderamento. Anais do II Seminário Nacional Movimentos Sociais, Participação e Democracia. Florianópolis, 2007, ISSN 1982-4602.

LOURO, G. L. Gênero: questões para a educação. In: BRUSCHINI, C.; UNBEHAUN, S. Gênero, democracia e sociedade brasileira. Fund. Carlos Chagas, Ed. 34, 2002.

LYRA, J. Gênero, saúde e análise de políticas: caminhos e (des)caminhos. Ciênc. saúde coletiva [online]. 2009, vol.14, n.4, pp. 1010-1012. ISSN 1413-8123.

MACHADO, P.S. O sexo dos anjos: um olhar sobre a anatomia e a produção do sexo (como se fosse) natural. Cadernos Pagu (24), janeiro-junho de 2005, p.249-281.

MACHIN, R. et al. Concepções de gênero, masculinidade e cuidados em saúde: estudo com profissionais de saúde da atenção primária. Ciência \& Saúde Coletiva, 16(11):4503-4512, 2011.

MALUF, M. R. Formação e atuação do psicólogo na educação: dinâmica de transformação. In: ACHCAR, R. (coord.) Psicólogo Brasileiro: práticas emergentes e desafios para a formação. São Paulo, Casa do Psicólogo, 1994.

MOUTINHO, L.; MONTEIRO, S., PINHO, O. \& CARRARA, S. Raça, sexualidade e saúde. Rev. Estud. Fem.[online]. 2006, vol.14, n.1, pp. 11-14. ISSN 0104-026X.

NASCIMENTO, M. \& CARRARA, S. Sobre "Homens, saúde e políticas públicas: a equidade de gênero em questão". Ciênc. saúde coletiva [online]. 2012, vol.17, n.10, pp. 2583-2585. ISSN 1413-8123.

NICHOLSON, L. Interpretando o gênero. Estudos Feministas, Florianópolis, v.8, n.2, p.942, 2000. Publicado originalmente em inglês, em 1994.

PATTO, M. H. S. Exercícios de Indignação: escritos de educação e psicologia. São Paulo, Casa do Psicólogo, 2005. 
PISCITELLI, Adriana. Re-criando a categoria mulher?. In: Algranti, Leila Mezan. (Org.). A prática feminista e o conceito de gênero. Campinas: IFCH/UNICAMP, 2002, v. 48, p. 7-42.

PORTELLA, A. P. Estratégias, desafios e limites na formação em gênero e saúde: reflexões a partir de uma experiência feminista. In: VILLELA W. \& MONTEIRO S. (orgs.) Gênero e Saúde: programa saúde da família em questão. Rio de Janeiro, Abrasco. Brasília, UNFPA, 2005 .

POUGY, L. G. Desafios políticos em tempos de Lei Maria da Penha. Katálysis. Florianópolis, v. 13, n. 1, p. 76-85, jan/jun 2010.

RAMIRO, Lúcia et al. Educação sexual, conhecimentos, crenças, atitudes e comportamentos nos adolescentes. Rev. Port. Sau. Pub. [online]. 2011, vol.29, n.1, pp. 11-21. ISSN 08709025.

ROCKWELL, E. Etnografia e teoria na pesquisa educacional. In J. Ezpeleta \& E. Rockwell (Orgs.) Pesquisa Participante. São Paulo: Cortez, 1989.

Reflexiones sobre el proceso etnográfico (1982-85). México: Centro de Investigación y Estudios Avanzados del Instituto Politécnico Nacional (Mimeo.).

ROHDEN F. Uma ciência da diferença: sexo e gênero na medicina da mulher. Rio de Janeiro, Editora Fiocruz, 2001.

ROHDEN, F. \& RUSSO, J. Diferenças de gênero no campo da sexologia: novos contextos e velhas definições. Rev. Saúde Pública [online]. 2011, vol.45, n.4, pp. 722-729.

Epub June 10, 2011. ISSN 0034-8910.

ROHDEN, Fabíola. Ginecologia, gênero e sexualidade na ciência do século XIX. Horiz. antropol. [online]. 2002, vol.8, n.17, pp. 101-125. ISSN 0104-7183.

ROSEMBERG, F. Educação formal, mulheres e relações de Gênero: balanço preliminar da década de 90. In: BRUSCHINI, C.; UNBEHAUN, S. Gênero, democracia e sociedade brasileira. Fund. Carlos Chagas, Ed. 34, 2002.

ROSEMBERG, F. Educação Infantil, Classe, Raça e Gênero. Cad. Pesquisa. São Paulo, n.96, p. 58-65, fev.1996. 
RUBIN, G. O tráfico de mulheres. Notas sobre a "Economia Política" do Sexo. Cadernos Pagu, n.21, p.1-64, 2003.

SCOTT, J. W. Gênero: uma categoria útil de análise histórica. Educação \& Realidade, Porto Alegre, n.20, v.2, p. 71-100, jul/dez, 1995.

Gender and the Politics of History. Columbia University Press, New York, 1988.

Igualdade versus diferença: os usos da teoria pós-estruturalista. Debate

Feminista (Cidadania e Feminismo), n. especial, p. 203-222, 2000.

STRATHERN, M. Necessidade de pais, necessidade de mães. Estudos Feministas, ISSN 0104-026X, v.3, n. 2. Florianópolis, Brasil, 1995.

TAVARES, M. Sexualidade e Educação Sexual. Rev. Lusófona de Educação [online]. 2006, n.7, pp. 145-147. ISSN 1645-7250.

VARGAS, E. P.; RUSSO, J. A. \& HEILBORN, M. L. Sexualidade e reprodução: usos e valores relativos ao desejo de filhos entre casais de camadas médias no Rio de Janeiro, Brasil. Cad. Saúde Pública [online]. 2010, vol.26, n.1, pp. 153-162. ISSN 0102-311X.

VIANNA, C. O sexo e o gênero da docência. Cadernos PAGU, Campinas: n17/18, 2001/02.

VIÉGAS, L. de S. Reflexões sobre a pesquisa etnográfica em educação e psicologia. N. 9. (101-124) Disponível em: <www.fsba.edu.br/dialogospossiveis>. Acesso em 20 jan. 2012.

VILLELA W. \& MONTEIRO S. (orgs.) Gênero e Saúde: programa saúde da família em questão. Rio de Janeiro, Abrasco. Brasília, UNFPA, 2005.

VILLELA, W. \& MONTEIRO, S. A promissora expansão do uso da categoria gênero pela Saúde Coletiva Brasileira. Ciênc. saúde coletiva [online]. 2009, vol.14, n.4, pp. 994-994. ISSN 1413-8123.

ZAGO, N. A entrevista e seu processo de construção: reflexões com base na experiência prática. In: Zago, N. Carvalho, M.P. Vilela, R. A. (orgs.). Itinerários de pesquisa. Rio de Janeiro, DP\&A, 2003. 


\section{APÊNDICES}

\section{APENDICE A - Centros de Referência da Prefeitura de São Paulo, Secretarias de Participação e Parceria e Secretaria Municipal de Saúde.}

\section{SECRETARIA DE PARTICIPAÇÃO E PARCERIA}

Centro de Referência em Direitos Humanos de Prevenção e Combate a Homofobia (CRDHPCH)

O Centro de Referência em Direitos Humanos de Prevenção e Combate a Homofobia coíbe e pune qualquer ação atentatória aos direitos humanos e prevê garantias fundamentais às pessoas em razão da sua orientação sexual e identidade de gênero. Neste centro, todas as denúncias recebidas serão encaminhadas à Secretaria da Justiça, por meio da Comissão Processante Permanente, para a instauração de processo.

\section{COORDENADORIA DA MULHER}

Centros de Referência e Atenção às mulheres que sofrem violência doméstica

São locais que tem o objetivo de dar atendimento psicológico, social e jurídico às mulheres que sofrem violência doméstica e familiar. Todos os atendimentos são gratuitos e disponíveis às moradoras do município maiores de 18 anos.

Casa Eliane de Grammont

Casa Brasilândia

Centro de Referência da Mulher

Centros de Cidadania da Mulher (CCMs)

É um espaço de qualificação e formação em cidadania ativa, onde mulheres de diferentes idades, raças e crenças possam se organizar e defender seus direitos sociais, econômicos e culturais, propor e participar de ações e projetos que estimulem a implementação de políticas de igualdade e potencializar, por meio do controle social, os serviços públicos existentes, de tal modo a atender às suas necessidades e da sua comunidade.

CCM PARELHEIROS

CCM PERUS

CCM CAPELA DO SOCORRO

CCM ITAQUERA 
CCM SANTO AMARO

COORDENADORIA DA DIVERSIDADE SEXUAL

Centro de Referência da Diversidade

O objetivo do Centro de Referência da Diversidade é desenvolver ações que possibilitem a garantia da inclusão social e a geração de renda na região central de São Paulo. É um espaço destinado a atender homens e mulheres profissionais do sexo; gays e lésbicas; travestis; transexuais e pessoas que vivem com HIV e aids em situação de vulnerabilidade e risco social.

\section{SECRETARIA MUNICIPAL DE SAÚDE}

\section{COORDENADORIA REGIONAL DE SAÚDE LESTE}

Maternidades da rede de proteção à mãe paulistana

H.M. Cidade Tiradentes

H.M. Prof. Alípio Correa Netto - Ermelino Matarazzo

H.M. Tide Setubal - São Miguel

Hospital De Guaianazes - Jesus T. Costa

Hospital Do Itaim Paulista

Hospital Do Itaim Paulista

Hospital Santa Marcelina De Itaquera

Hospital Geral S. Mateus - Manoel Bifulco

Serviços De Pré-Natal De Alto Risco

Amb. Espec. Penha - Dr. Maurice Pate - Penha

Amb. Espec. Tito Lopes Da Silva - São Miguel

UBS Jardim Camargo Novo - Itaim Paulista

Hospital Do Itaim Paulista

Hospital Do Itaim Paulista

Hospital Do Itaim Paulista

Hospital De Guaianazes - Jesus T. Costa

Hospital Santa Marcelina De Itaquera

Serviços Que Atendem Mulheres Vítimas De Violência Sexual E Doméstica

H.M. Dr. Cármino Caricchio - Tatuapé

H.M. Dr. Alexandre Zaio

Hospitais Que Realizam Aborto Previsto Por Lei (Aborto Legal) 


\begin{tabular}{|l|}
\hline Amb. Espec. José Bonifacio Iv - Itaquera \\
\hline Amb. Espec. Tito Lopes Da Silva - São Miguel \\
\hline H.M. Tide Setubal - São Miguel \\
\hline H.M. Prof. Dr. Waldomiro De Paula - Itaquera/Planalto \\
\hline H.M. Prof. Dr. Waldomiro De Paula - Itaquera/Planalto \\
\hline Mamógrafos \\
\hline Amb. Espec. José Bonifacio Iv - Itaquera \\
\hline Amb. Espec. Tito Lopes Da Silva - São Miguel \\
\hline Amb. Espec. São Carlos - Guaianases \\
\hline Centro De Diagnóstico Imagem De São Matheus \\
\hline UBS Burgo Paulista \\
\hline H.M. Cidade Tiradentes \\
\hline Consultas De Mastologia \\
\hline AE José Bonifácio Iv \\
\hline UBS Burgo Paulista \\
\hline UBS São Mateus I \\
\hline Colposcopia - Cidade Tiradentes \\
\hline Casa Ser \\
\hline STS Ermelino Matarazzo \\
\hline Umb. Espec. Vila Paranaguá Humberto Cerrutti \\
\hline Densitometria Óssea \\
\hline C.D.I. São Mateus \\
\hline
\end{tabular}




\section{APÊNDICE B - Roteiro de entrevista inicial}

\section{ROTEIRO DE ENTREVISTA}

21/06/2010

ENTREVISTADORA: Ângela Esteves Modesto

ENTREVISTADA: Laura, enfermeira, funcionária da casa há 4 anos

\section{Início: $13 \mathrm{~h} 20$ - Fim: $14 \mathrm{~h} 45$}

1. Como começou a Casa Ser? Quando?

2. Qual a sua função?

3. Quais atividades são desenvolvidas aqui?

4. Vocês trabalham com a Lei Maria da Penha?

5. A Lei prevê medidas integradas de prevenção, certo? Vocês trabalham com alguma dessas medidas?

6. Quais os conteúdos trabalhados?

7. Vocês trabalham com (o tema) gênero? Como?

8. Qual a maior dificuldade para trabalhar com esse tema? Por quê?

9. Todos os funcionários partilham o mesmo conceito de gênero?

10. Há algo que eu não tenha perguntado, mas que você queira falar? 


\section{APÊNDICE C - Roteiro de entrevista para funcionária}

\section{ROTEIRO DE ENTREVISTA}

Data:

ENTREVISTADORA: Ângela Esteves Modesto

ENTREVISTADA:

Início: - Fim:

Abordagem: minha apresentação e breve explicação sobre o projeto, objetivos, etc.

1. Qual é o trabalho realizado aqui na Casa Ser?

2. Qual é a função que você desempenha aqui?

3. Quais são as suas principais atividades?

4. Quais são os conteúdos trabalhados nas suas atividades?

Se não mencionar gênero,

5. Você trabalha com (o tema) gênero?

6. O que é gênero, em sua opinião?

7. Em relação a este assunto, há algo mais que você queira falar? 


\title{
APÊNDICE D - Exemplo de TCLE
}

\author{
TCLE - Participantes maiores de 18 anos
}

TERMO DE CONSENTIMENTO LIVRE E ESCLARECIDO

INFORMAÇÕES SOBRE A PESQUISA:

Título do Projeto: Gênero, educação e prevenção: práticas educativas com foco em gênero.

\section{Pesquisador Responsável: Ângela Esteves Modesto}

Telefone para contato (inclusive ligações a cobrar): (11) xxxxxxxx

Este trabalho tem por objetivo conhecer as atividades realizadas nesta instituição que falam sobre violência contra a mulher, Lei Maria da Penha e sobre gênero. As informações serão coletadas por meio de entrevistas individuais, coletivas, observação e análise de documentos. Você está sendo convidado(a) a participar de uma entrevista individual com duração aproximada de uma hora, que será anotada e gravada. A qualquer momento você pode pedir maiores informações, inclusive relativas à como o trabalho será realizado. As responsáveis pela pesquisa garantem o sigilo que assegure sua privacidade quanto aos dados envolvidos na pesquisa - seu nome não será revelado e seu depoimento será usado somente para a finalidade da pesquisa. Você tem o direito de se recusar a participar ou a retirar seu consentimento a qualquer tempo e sem quaisquer prejuízos para seu atendimento pela instituição. As informações obtidas só podem ser usadas para fins científicos, de acordo com a ética na pesquisa.

Sua participação não será remunerada e ajudará a entender como estão acontecendo as atividades preventivas à violência doméstica e de gênero na sua comunidade.

Dúvidas referentes à ética desta pesquisa poderão ser encaminhadas ao:

Comitê de Ética em Pesquisa da Secretaria Municipal da Saúde - CEP/SMS Rua General Jardim, $\quad 36 \quad-\quad 1^{\circ}$ andar Informações/ dúvidas: Fone: 3397-2464 / Fax: 3397-2465 OU por e-mail: $\underline{\text { smscep@gmail.com }}$ 
$\mathrm{Eu}$, abaixo assinado, concordo em participar do estudo 'Gênero, educação e prevenção: práticas educativas com foco em gênero' como sujeito. Fui devidamente informado e esclarecido(a) pela pesquisadora Ângela Esteves Modesto sobre a pesquisa, os procedimentos nela envolvidos, assim como os possíveis riscos e benefícios decorrentes de minha participação. Foi-me garantido que posso retirar meu consentimento a qualquer momento, sem que isto leve a qualquer penalidade ou interrupção de meu acompanhamento/ assistência/tratamento.

São Paulo, de de

Nome do(a) participante:

Assinatura do participante:

Assinatura da pesquisadora responsável pelo recebimento do TCLE: 


\section{APÊNDICE E - Exemplo de Registro Ampliado 1 - Oficina de artesanato}

\section{REGISTRO AMPLIADO}

13/09/2011

Casa Ser

Atividade: Reunião inicial com Coordenação

Início: 13h - Fim: 14h20

\section{Sala da coordenação}

Chego à Casa, me apresento ao recepcionista, que me parece ser o mesmo que me recebeu na minha primeira visita, no ano anterior. Digo que preciso tenho uma reunião com Rose marcada para as 13 horas. O funcionário me diz que posso entrar e ir até a sala de Rose, apontando-me o caminho.

Vou até a sala indicada, onde há algumas mulheres reunidas, e pergunto por Rose. Ela se identifica, levanta-se e me pede para entrar e sentar em frente à sua mesa. Apresenta a seguir as outras pessoas da sala, Danusa e Marta, assistentes sociais.

Explico resumidamente minha história de contato com a Casa desde os primeiros contatos até a aprovação de meu projeto pelo Comitê de Ética da prefeitura de São Paulo, enfatizando minha dedicação para que pudesse finalmente realizar minha pesquisa lá. Rose reconhece o esforço e concorda sobre a dificuldade de aprovação de alguns projetos.

Pergunto se ela recebeu e leu o meu projeto de pesquisa que havia enviado alguns dias antes. Ela titubeia e não confirma o recebimento, passando imediatamente a tentar localizar o email no computador. Ao encontrar, diz que não havia lido. Explico, então, quais os objetivos da minha pesquisa e como a pretendo realizar, perguntando se posso contar com ela para me ajudar com a mobilização dos grupos, da equipe, das usuárias e grupo de jovens multiplicadores, ao que ela responde positivamente, acrescentando que todas as atividades da Casa têm foco em gênero, tanto as de prevenção como as médicas, oficinas, etc., apesar de a Casa ter um viés médico, por ser um centro médico.

Conta que a ideia da Casa começa com o movimento da Marcha das Mulheres, de se ter um centro médico que desenvolvesse atividades de prevenção com foco em gênero. $O$ estabelecimento da Casa foi possível devido a uma parceria da prefeitura com o Consulado o Japão. Eu já conhecia esses dados da primeira entrevista.

Ela parece, a seguir, querer me situar quanto à situação da Casa em relação à prefeitura. Menciona que ela e Danusa, assistente social, são emprestadas da Coordenadoria 
de Saúde e podem ser transferidas, devido à natureza do cargo. Diz também que não vê muito sentido em a Casa responder à Secretaria Municipal de Saúde e não à Secretaria de Participação e Parceria (dentro da qual está a Coordenadoria da Mulher), pois isso coloca a Casa como mais propícia ao desenvolvimento de ações de saúde que de gênero. Pelo tom com que me conta esses fatos, parece bastante insatisfeita.

Pergunto sobre o grupo de adolescentes multiplicadores da escola do bairro, mencionado pela enfermeira Laura no ano passado (grupo pelo qual tenho bastante interesse), e ela reforça que há atividades de formação de educadores (ou multiplicadores), pois para reunir todas as crianças em um único espaço ficaria muita bagunça. Conta que, por enquanto, não estão fazendo o acompanhamento das atividades dos multiplicadores por que não há equipe suficiente e complementa "Não tenho pernas pra isso". Comenta logo em seguida que Laura, pessoa mais próxima do grupo da escola, está em férias e que eu precisarei esperar pelo retorno dela para ter alguma informação sobre o grupo de jovens.

Fico um pouco receosa, pois havia pensado em realizar a maioria das visitas à Casa no mês de setembro, por estar de férias, mas como fica claro ao longo da conversa que é Laura quem encabeça grande parte das ações da Casa, percebo que será necessário prorrogar as visitas.

Sou informada pela coordenadora e por Danusa sobre a agenda do mês, sou convidada a participar das atividades, identifico as principais que pretendo acompanhar e Rose, notando que estaria presente em uma das reuniões com o Conselho Gestor da $\mathrm{Casa}^{27}$, diz, rindo: “Ah, então eu vou passar tarefa de casa, eu adoro passar tarefa de casa!”. Não digo nada e aguardo para saber qual seria a tarefa, preocupada pela possibilidade de ela não ter entendido que eu estaria ali como pesquisadora e não como estagiária ou alguma outra função. Ela me pede para apoiar Marta nos comentários do filme que seria passado na reunião como o Conselho. Digo que estarei presente e que sim, poderia apoiar, mas que, entretanto, preferia fazer comentários pontuais, pois estaria como observadora e não facilitando a reunião.

Pergunto sobre o Conselho, o que faz, como atua, etc., e ela me explica que a Casa é a única da região que não tem área delimitada. As UBS tem, os CTAs tem, então seus conselhos são compostos por pessoas dos bairros mais próximos, o que não acontece na Casa, em que o Conselho é composto por lideranças comunitárias que nem sempre são tão atuantes quanto deveriam ser. O Conselho é composto só de mulheres, é o que está no regimento da Casa, que exercem mais um papel político na área, mas não são envolvidas no trabalho da Casa. A

\footnotetext{
${ }^{27}$ Mulheres líderes comunitárias de bairros da localidade.
} 
atividade do dia seguinte seria a exibição de um filme para aproximar o Conselho da Casa e foi pedido que trouxessem mais alguém, para incentivar a renovação do Conselho e de suas opiniões.

Confirmo minha presença para o dia seguinte. Rose diz que precisa sair, eu agradeço e digo que observarei um pouco na sala de espera. Antes de sair, Marta me pede materiais sobre gênero, diz que trabalha ali há dois meses apenas e que nos encontros de planejamento ela fala sobre métodos anticoncepcionais e cirurgias definitivas. Quem quer agendar a cirurgia, 2 sábados por mês, já podem consultar diretamente a médica, mas que a intenção é que as mulheres não optem pelo método definitivo. Só nesse com esse comentário eu percebo que a palavra "planejamento" que elas estavam repetindo constantemente se referia a expressão "planejamento familiar" e não ao planejamento das atividades da Casa, como eu havia interpretado. Digo que sim, que indicaria os materiais a ela.

\section{Sala de espera}

Sentada em um dos jogos de cadeiras da sala onde 9 pessoas estão presentes, entre elas três homens, provavelmente acompanhantes das esposas, ouço uma voz masculina dizendo algo como "Extração de mamas é com você?". Provavelmente as outras pessoas também ouviram. Ouço risos vindos da sala dos funcionários. Ninguém que está esperando se manifesta ou parece se abalar. Eu havia achado o comentário minimamente grosseiro e que não deveria ter sido comentado publicamente.

Aos poucos, as pessoas vão sendo atendidas e, como tenho um compromisso em seguida, me despeço e vou embora. 


\title{
APÊNDICE F - Exemplo de Registro Ampliado 2 - Grupo de Planejamento Familiar
}

\section{RELATO DE OBSERVAÇÃO \\ 15/09/11}

Casa SeR

\author{
Atividade: Reunião de Planejamento Familiar \\ Início: 13h - Fim: ---- \\ Presentes: 7 mulheres \\ Coordenadora do grupo: Silvia, com apoio de Marta
}

Impressões: As coisas me parecem desorganizadas na Casaser. Tenho a impressão de que o plano para a reunião de planejamento que se iniciará está sendo feito agora, dois minutos antes de a reunião começar. Sinto um pouco de rechaço das funcionárias quanto à minha presença. Estão menos calorosas que no primeiro dia. A coordenadora não está hoje e nem estava ontem.

A reunião do grupo se inicia com uma greve apresentação do que é a Casaser por Silvia para o grupo de mulheres: é um centro de saúde sexual e reprodutiva que visa à prevenção para mulheres e homens. Silvia continua explicando que o planejamento familiar é uma atividade obrigatória, prevista em lei, para locais que realizam ou encaminham para métodos contraceptivos definitivos, como laqueadura e vasectomia.

Uma outra parte da explicação introdutória aborda o procedimento que se seguirá para aquelas mulheres: são dois encontros no coletivo (com o grupo), quem decidir por um método definitivo agendará ao final uma entrevista e depois passará com a médica; quem quiser atendimento individual, poderá pedir também ao final.

A apresentação das pessoas do grupo inclui nome, idade, estado civil, número de filhos, se usa método contraceptivo, se quer trocar de método ou conhecer outro método. Entre as respostas, muita heterogeneidade: 2 querem conhecer métodos, três já fazem uso de algum método, 2 querem engravidar, 1 vai casa, quer saber sobre os métodos e nunca passou por um médico, etc. Esta última é convidada a participar do grupo de planejamento com adolescentes, creio eu por sua pouca idade se comparada à idade das demais.

Dito isso, Silvia diz que será passado um curta-metragem sobre o qual haverá uma discussão posteriormente.

O curta é “Acorda, Raimundo!”, protagonizado por Paulo Betti e Eliane Giardini. 
Depois do filme, Marta conduz uma discussão sobre ele. As mulheres comentam: "Os homens não se colocam no lugar da mulher, acham que têm razão"; "Minha amiga acha que tem que chegar antes em casa para deixar tudo pronto, casa limpa, comida e bebê pronto".

Silvia complementa: "O marido sempre ajuda em casa; a responsabilidade é da mulher e o marido vai ajudar. A família é dos dois, tem que ter divisão das tarefas. Ajudar é diferente de participar, de companheirismo. No filme, ele pode bater nela. Ele pode ficar no bar e ela não. A sociedade ensinou que homem pode bater na mulher por que é mais forte. A mulher passou a trabalhar, a sociedade colocou isso e nós fomos reproduzindo. A mulher quando trabalha pode querer benefícios para ela própria ou ela quer o salário do marido na mão, mas por que, se é parte da família? Por que não fazer o orçamento e gastar junto?

Para alcançar a autonomia feminina, muitas sofreram para hoje ter mulher motorista, mulher engenheira, mulher presidenta...mesmo ainda ganhando menos.

São desigualdades de gênero (apontando para mim). São características do masculino e do feminino - a mulher fica em desvantagem, sai perdendo.

O homem também quer saber sobre o corpo. Se engravida, é ‘por que engravidou?', mas fala 'eu não vou usar camisinha por que é chupar bala com papel'..."

Em seguida, Silvia dá um exemplo da série de TV Malhação em que um dos personagens não quis usar camisinha e a menina não quis ficar com ele. Emenda: "decisão do homem / decisão da mulher".

$\mathrm{Na}$ sequência, introduz um assunto novo: "Antigamente, com a guerra, as mulheres trabalhavam e as crianças também. O que vão fazer com as mulheres? Vamos criar um mundo de máquinas para elas! Batedeira, como fazer, como tratar o marido, não fazer perguntas para atrapalhar, etc.".

E continua: "Homem é livre para exibir o órgão para fazer xixi e a menina fecha as pernas. São atitudes pequenininhas que reproduzimos com os filhos, os vizinhos, etc., que perpetuam a situação das mulheres.

Menina fecha as pernas por que o órgão é feio! O menino pega, se conhece, mexe, fica ereto... vai pegar todas! Pra menina, isso é sujo! Não pode! Temos que saber que ela tem o encanto dela!"

Silvia se refere à vagina e cita alguns nomes pelos quais ela é normalmente chamada, e continua:

“Antes eles eram mais feios, hoje são mais bonitos... ela é nossa, faz parte do corpo. É bom olhar com espelhinho... todo dia se olha no espelho, tem que olhar ela, cuidar dela. Os nomes 
para o pênis demonstram poder, diferente dos nomes para a vagina. O órgão do prazer para o homem é?"

As participantes respondem: "O pênis".

Ela segue: "E o da mulher é?"

Aí, as respostas diferem entre vagina e clitóris.

Silvia continua: "Há desigualdade entre homem e mulher. A mulher, começou a ter relação sexual, tem que passar no ginecologista. Ele tem que saber tudo de mim. Somos acostumadas a isso. Precisamos conhecer o corpo e os métodos para poder escolher e propor para o ginecologista.

Um jovem casal, que participa do grupo (o rapaz chegou depois do início), coloca uma questão. Ela diz que tem 25 anos, 2 filhos e que querem fazer laqueadura ou vasectomia. Parece que o casal ainda não se decidiu. Silvia diz: "Pode fazer, é fácil, mas tem que pensar bem...". Ela segue:

"Sexualidade, vocês pensam em que?" Respostas: sexo, opção sexual, maneiras de sentir prazer no corpo, intimidade do casal, etc.

Ela segue: "Tem a ver com prazer, com a maneira que o ser humano tem de sentir prazer. É como comer e beber, cada um tem o seu prazer, com o cheiro, visão, toque, com os sentidos. Tem a ver com hormônios, métodos, etc.

A mulher dá e recebe. Não tem 'perder a virgindade'. Não perde, e sim, ganha nova vida sexual. A gente pensa que só o homem recebe...

Neste momento, um deslocamento no tema acontece e uma das participantes comenta o Sistema Municipal de Notificação, onde há registros de ocorrências. Trata-se de um site da prefeitura. Ela diz que vai auxiliar o investimento financeiro e trazer o Caps, Caps AD, Naps, etc., e afirma que o banco de dados está com os dados atrasados. Pelo que entendi, o banco tem informações acerca de violências e acidentes (saúde / notificações de violência), mulheres, domésticas, negras e com baixa escolaridade. Também haverá divulgação dos locais para atendimento de violência e distribuição de panfletos.

Segue-se uma explicação sobre o que seria violência, com um comentário: "Estupro que a mulher 'deixa' sem perceber - “cuspiu dentro de mim”, “jogou dentro de mim”.

Silvia pega outro cartaz explicativo, desta vez com a imagem do corpo de uma mulher e pergunta: "Vocês são assim?" ao que uma das participantes responde: "Não com esses pelos todos!’. Todas riem.

Silvia pergunta para Marta sobre o cartaz com a imagem do corpo do homem. Ela procura o cartaz, mas não o encontra. 
Silvia pergunta: "Útero serve pra que?". A resposta de uma participante: "Pra gerar bebê." Silvia complementa "No ovário se produz óvulos. Tem muita diferença entre o homem e a mulher? Sim. Mas isto nos torna diferentes? Não. A mama da mulher se desenvolve para que?". Participantes: "Para amamentar.".

Silvia: "Qual o aparelho reprodutivo dos homens?". Participantes: “Testículos?”. Silvia explica: "Os testículos são cheios de espermatozoide, servem para a proteção das células do homem. No calor, aumenta, e no inverno, diminui. A bexiga não aparece no desenho do corpo da mulher, mas sim no do homem, por que ela faz parte do sistema reprodutivo dele. Para que serve o pênis?". Participantes: "Para penetrar"; "Para fazer xixi”.

Silvia: "Por isso o homem não consegue transar se estiver de bexiga cheia, a mulher pode fazer xixi enquanto transa. O Homem tem o orgasmo pelo pênis, a mulher pelo clitóris, que é feito do mesmo tecido que o pênis. Vocês sabiam que nós também temos nosso pênis? Nosso pênis pode chegar a 18 centímetros!".

Participante: “Ah, então é por isso que tem mulher que é sapatão!?”. Silvia: "Não, isso é outra coisa... O clitóris quanto é tocado fica inchado, incha tudo por dentro. Não é fechado, é aberto por dentro. É mais rico de tecidos do que o pênis do homem. Depois de ejacular, o homem precisa parar. A mulher, quando termina, pode continuar. O clitóris é como um 'pênis embutido'. Onde é nossa fonte de prazer? No clitóris. Para que a vagina serve?". Participantes: "Pra saída de menstruação"; "Por onde sai o bebê no parto normal"; "Para penetração".

Silvia: "Vão pensando nos tipos de prazer. Pensem em algo que dê prazer pra vocês ou em comer algum alimento que você goste, chupar ou tomar um sorvete. Isso para o próximo encontro. Pensem em pergutas."

As participantes se dispersam e o grupo termina. 
ANEXOS

ANEXO A - Páginas da Cartilha para Profissionais de Saúde ${ }^{28}$

Relações Sociais de Gênero

A opressão das mulheres é localizada nas relações de desigualdade de gênero*, gerando um dos mecanismos mais importante da exclusão social das mulheres sua subordinaçăo aos homens, e syues conseqüencias mais severas aparm quando a essa condição da subordinação, soma-se a pobreza.

O feminismo, como movimento político de construção de igualdade entre mulheres e homens ressurge no final dos anos sessenta 40 (śćculo XX, tendo como o eixo central à luta pela transformação das relaçбes de gênero. Entre as conquistas obtidas a partir da ação do feminismo, encontram-se os direitos sexuais e reprodutivos.

As questöes inerentes à concep̧̧ão e anticoncepção formam o núcleo desses direitos, sendo importante lembrar a conexão estreita com as questões da sexualidade. $O$ fundamento desses direitos diz respeito à liberdade de escolha no campo reprodutivo, o que significa que a gravidez, parto, contracepção, aborto, maternidade fpaternidade, devem ser visto como fatos inter-relacionados, onde qualquer restrição à liberdade e garantias a cada um desses eventos, remete as pessoas, e, sobretudo as mulheres, a um lugar de opressão e dominaçăo. (Vilela 2000)

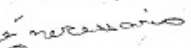

A Coordenadoria da Mulher entende que semincorporar o recorte de gênero e raça em ações da saúde, não há como concretizar relaçóes eqūitativivas entre sexos e melhorar a qualidade da vida das mulheres, por isso elaborou essa cartilha, com objetivo de sensibilizar gestores públicos e profissionais de saúde sobre a importância das questôes dos Direitos Reprodutivos e dos Direito Sexuais. .....

${ }^{*}$ Ge̊nero $\hat{e}$ um elemento constitutivo de relaçúes sociais fundada sobre as diferenças percebidas entre os sexos, é uma forma primária de dar significado as relaşóes de poder. Scott1991.

Cartilha, p.9, em que se menciona o conceito de gênero de Scott.

${ }^{28}$ As anotações do texto constavam do original. 


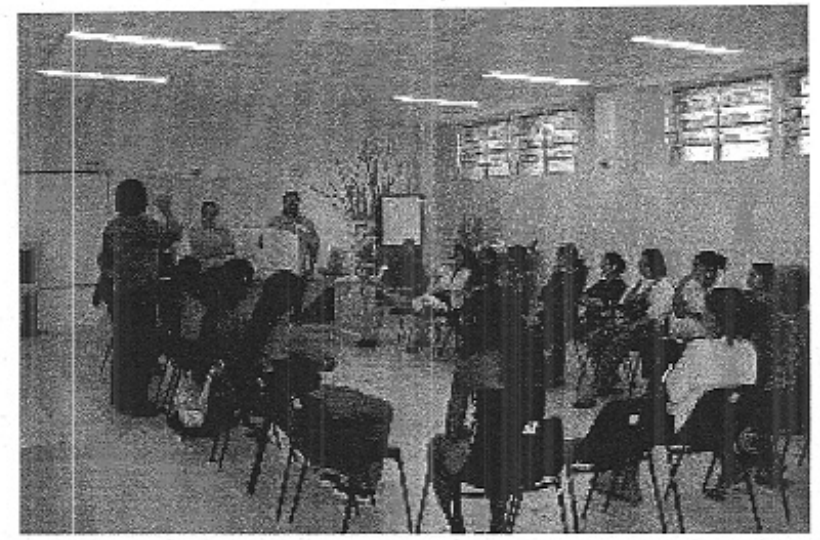

Gênero para quê?

Sexo: Comumente refere-se às caracteristicas biofisiológicas que diferenciam as mulheres dos homens. Alude às características dos aparelhos reprodutivos de umas e outros, seu funcionamento, assim como as caracteristicas sexuais".

(Saúde a Gênero: manual para equipes de saúde. Montevidéu/FNUAP, 1998).

Gênero: refere-se à criação sócio-cultural de idéias e atitudes sobre o masculino e o feminino, atributos, papéis e características de identidade, esperáveis para as mulheres e e neos homens em determinado momento histórico. Então, gênero é uma categoria social que molda os individuos de sexo masculino e feminino, com expectativas sociais que se impõem sobre os corpos de homens e mulheres.

O enfoque de gênero permite observar que: não existe essência feminina e masculina biologicamente determinada. Por exemplo, a capacidade de engravidar das mulheres não determina sua condição de dependência e subordinação aos homens.

Cartilha, p.16, em que se fala da abordagem de gênero. 
- As visões sobre o corpo, a sexualidade e os papéis de mulheres e homens não são fixos, nem determinados pela natureza, e sim, pela história. Mudam a partir dos padrōes socialmente construídos para o masculino e o feminino em uma determinada época e lugar.

É necessário trabalhar a sexualidade - a história, as crenças, as proibiçôes, os mitos e os tabus.Os significados que cada sociedade em diferentes épocas, constroem em relação à sexualidade enela aos papéis atribuidos às mulheres e homens para o exercício da mesma, os quais influem diretamente na saúde sexual e reprodutiva.

A sexualidade é uma dimensão central da subjetividade das pessoas:

"Faz parte da vida, integra e expressa a forma de estar no mundo das relaçōes humanas, da comunicação consigo mesma e com o outros". Cupes de openc?

Como eixo da construção da identidade pessoal, a sexualidade ao fazer parte das relações humanas não é áalheia à problemática do poder. Por exemplo, quando se vai discutir ou negociar com o parceiro o uso da camisinha, quando se vai compartilhar e escolher a utilização de métodos para evitar filhos, prevenir as DSTs/AIDs etc.

A visão estereotipada de uma "natureza feminina e masculina", como opostas e diferentes, cria relaç̋̃es de poder entre os sexos ou de gênero e estabelece controles sobre o exercício da sexualidade feminina e seu direito ao prazer.

Segundo, Silver (2000) as autoras Corrêa e Petchesky (1994) propõem quatro princípios para a constituição das bases éticas dos direitos sexuais e reprodutivos:

1. princípio da integridade corporal que inclui:

" $O$ direito da mulher de não ser alienada de sua capacidade sexual e reprodutiva (por exemplo, pelo sexo e casamento forçado),(....)negação de acesso à anticoncepção, esterilização sem consentimento informado(...) como também da integridade de stá pessoa fisica (por exemplo, liberação de violência sexual, do encarceramento doméstico, de métodos anticoncepcionais inseguros, de gravidez indesejada, ou

Cartilha, p.17, continuação sobre a abordagem de gênero. 
ANEXO B - Páginas dos Boletins Informativos

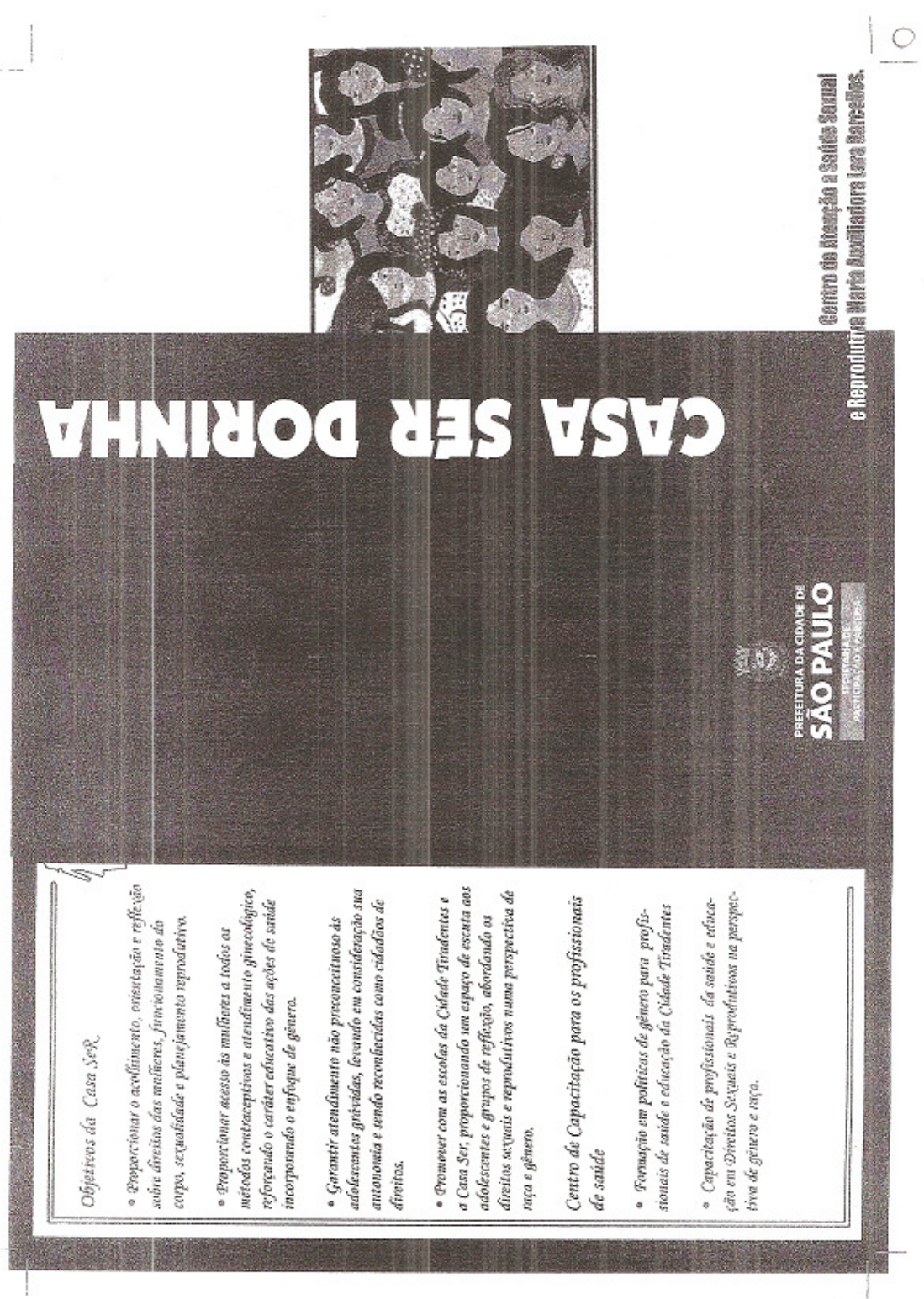

Boletim Informativo que apresenta os objetivos da Casa Ser. 


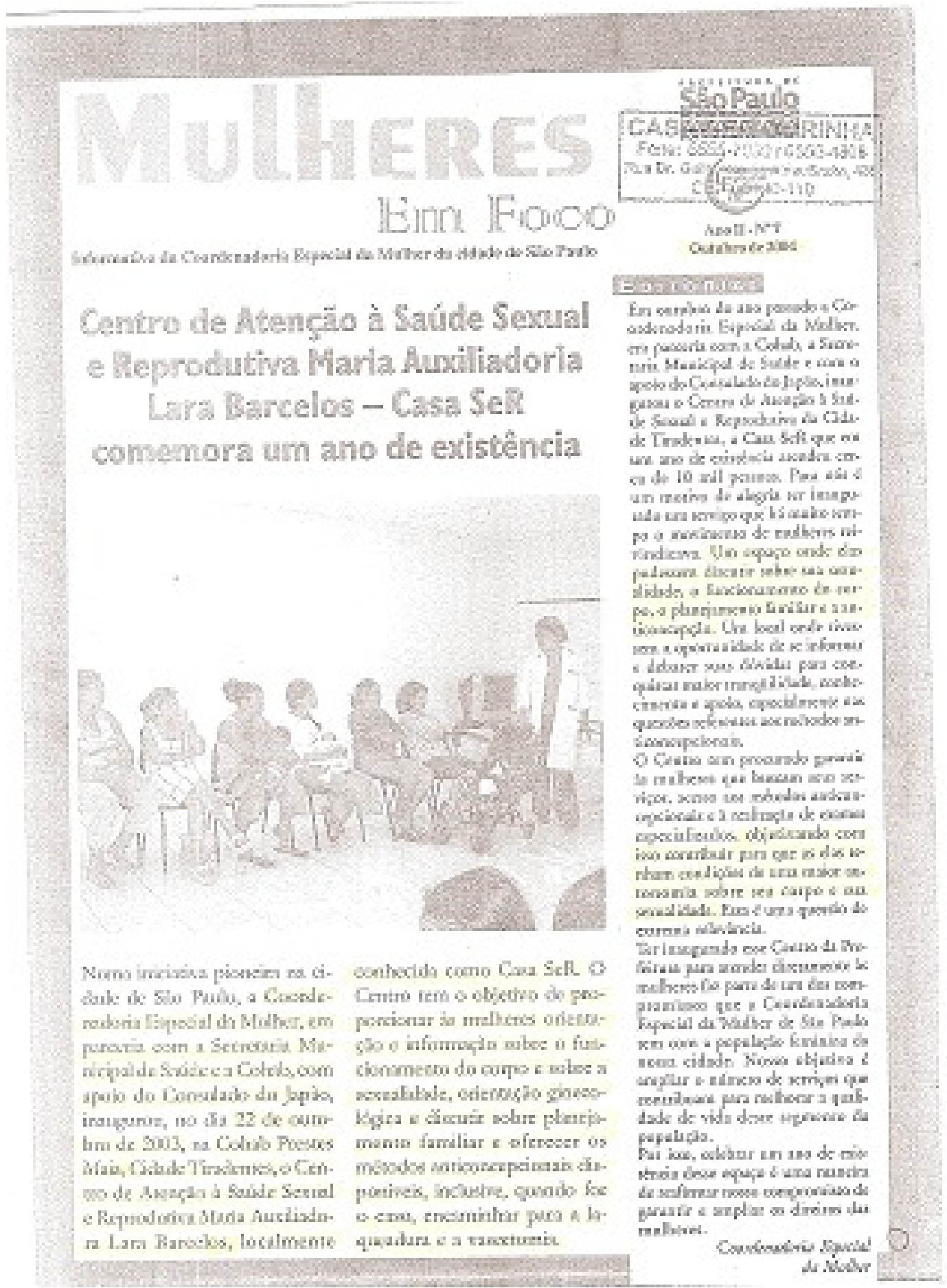

Boletim Informativo em comemoração a um ano de ano de existência. 
Coordenadoria Especial da Mulher:

Políticas públicas para construir a igualdade e combater a discriminação

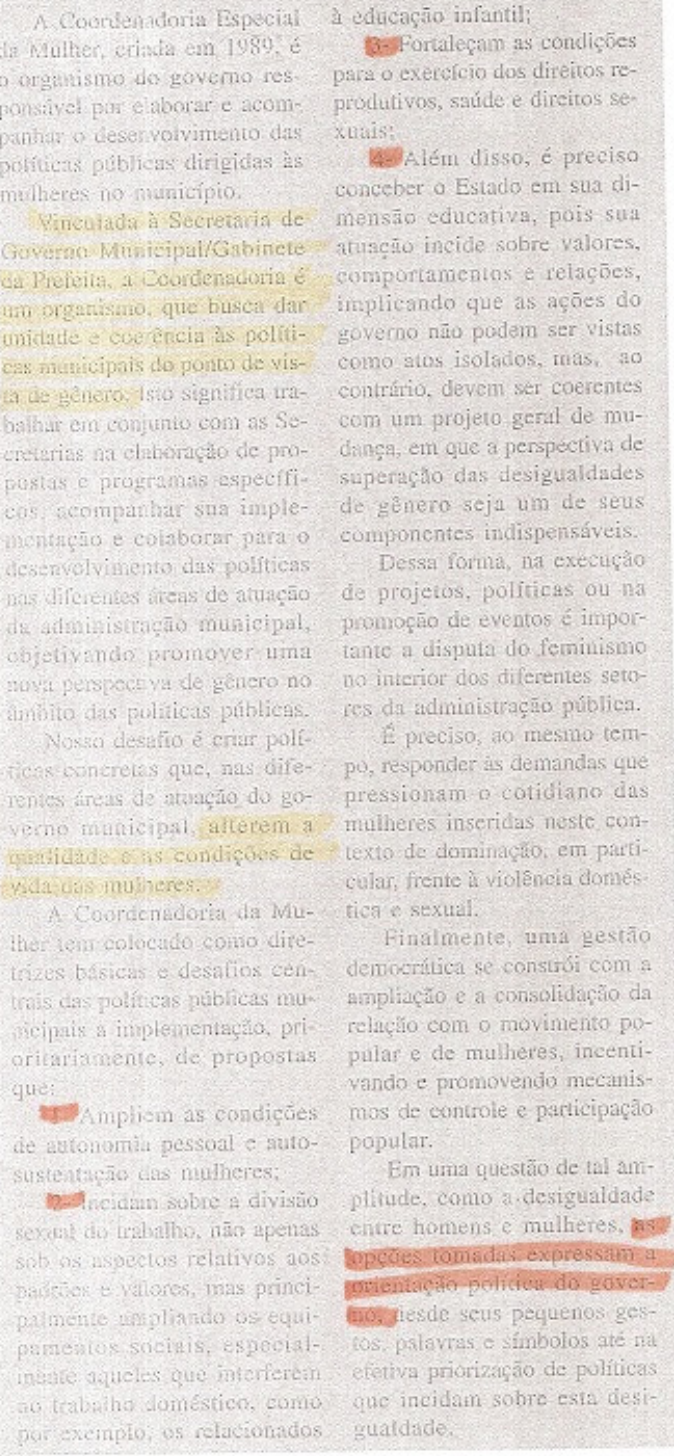

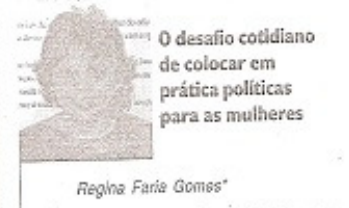

Trabalhar na Casa SeR Dorinha um desafio constante. Exige de nós, profissionais, uma açăo internós, profissionais, uma aça interna e exlema de revistón de padides, demandas das mulheres.

A descoberta, o encantamento, a formaçāo, a informaçẵo, a motivaçāo e incentivo fazem parte do cotidiano de todos nós da te do cotidia
Casa Ser.

Eu me vejo, e vejo a equipe de profissionais e a comunidade, percebendo e experimentando novas formas de "Ser" e "agir" no mundo de nossa (des)conhecida mulher. É possível ver o reflexo da presença do Centro de Aiençăo à Saúde Sexual e Reprodutiva no diaa-dia das mulheres,

Pensar e realizar políticas públicas que levem em consideração as questōes de gênero, e que atuem integralmente na saúde sexual erm incegralna desafio, Implementá-las no cotidiano das mulheres é uma construçāo prazerosa, encantadora e desafiadora da qual faço parte.

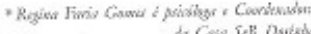
a Cos Sell Dsista

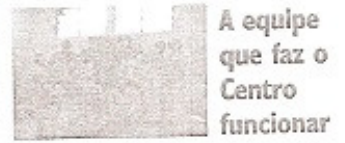

Equipe do Centro de Atençấo à Saúde Saxual o Reprodutiva: Eliana Dies do Nascimento, Marngal Aparecida do Paula e Luscileice Claudino Siradas Santos (edministrativo); Seltza Ferreira das Santos, Sivia Regina Ganbosa, Mania de Fátima Sauza Santos, Francelli ficcouri Castro, Fäbio Pereira Santana e Janaina Ferreira Nobre 〈auxiliar da enfermagan', Meria Neicie Finlo, Joel Natioxidada ce Bemos a Eulseses José da Síva (agante de agnia); Mórica Glyobolo Coeta da Cervaho [entemnera) Márcia Eiodória (assistente sccial); Rebosca Lea Barger (josicólcga); Roberio de Souza Damiáa a

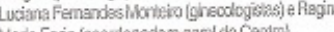
Wedia Fania (ccordenedana gard do Ceniro\}.

Colaboradoras da Coordenadorla Espocial dis Mulher: Ana Lúcia Cavalcanti (gineoslogista, responsável palo acompenhimanan

Boletim Informativo com posicionamento da Coordenadoria da Mulher. 


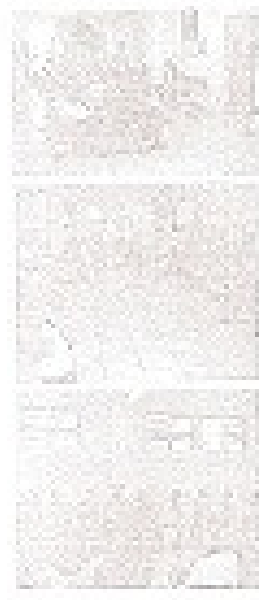

En wn ano Casa SaR rodina atwdades o atendimentos para cenca de 10 mil pessoos

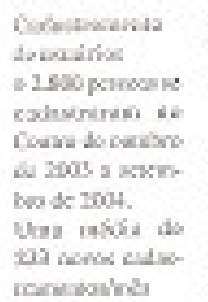
Tardothes

Gewind Hms Themin

4 +fol wathe

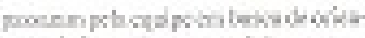

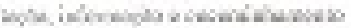

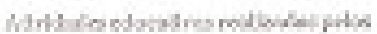

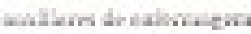

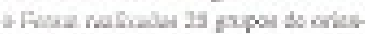

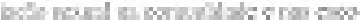

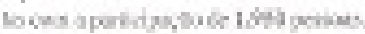

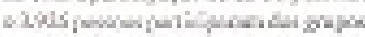

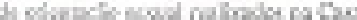
st:

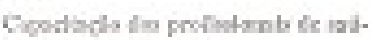

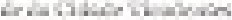

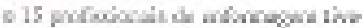

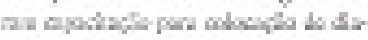
Trens:

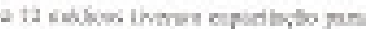
whenth th IIH

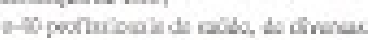

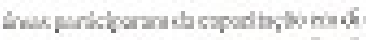

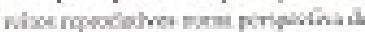

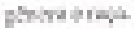



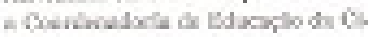
Ahth Thinirs

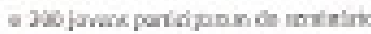

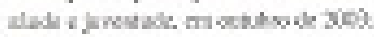

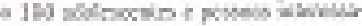

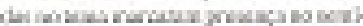

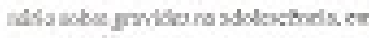
at in sa:

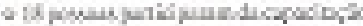

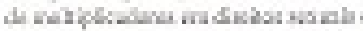
suveline

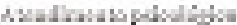

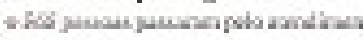

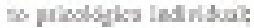

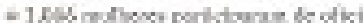

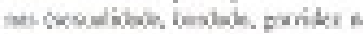

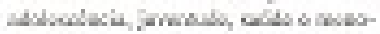
Frab.

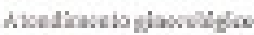

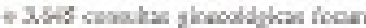

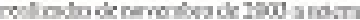
tou Ho:

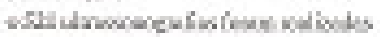

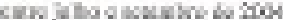

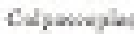

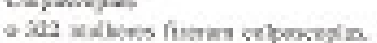

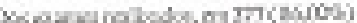
Adsuth promidhoths w

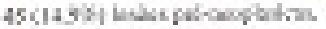

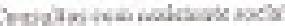

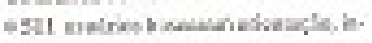

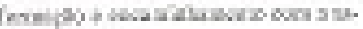
hitestrit



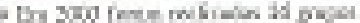

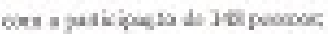

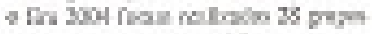

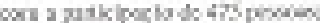

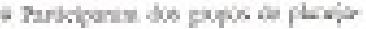

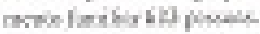



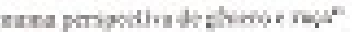

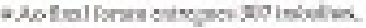



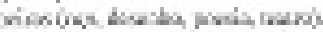

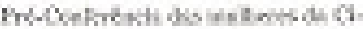
dimtorathas

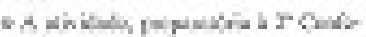

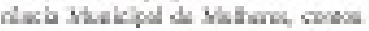

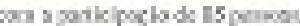

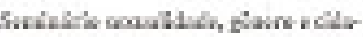
Inis

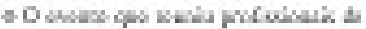
काm Fark.

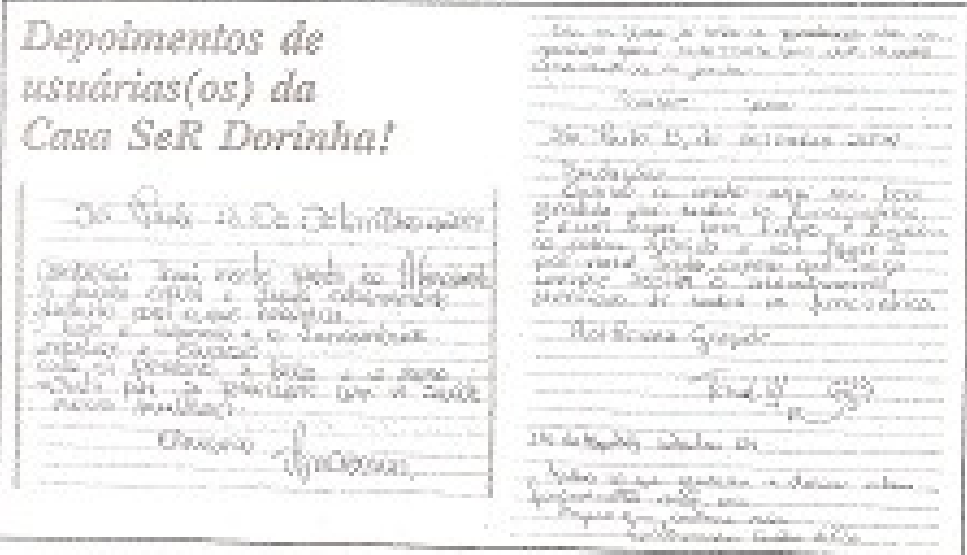




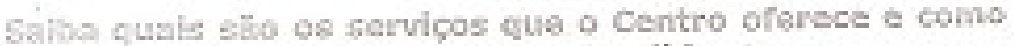
tozer pera sor abendidh

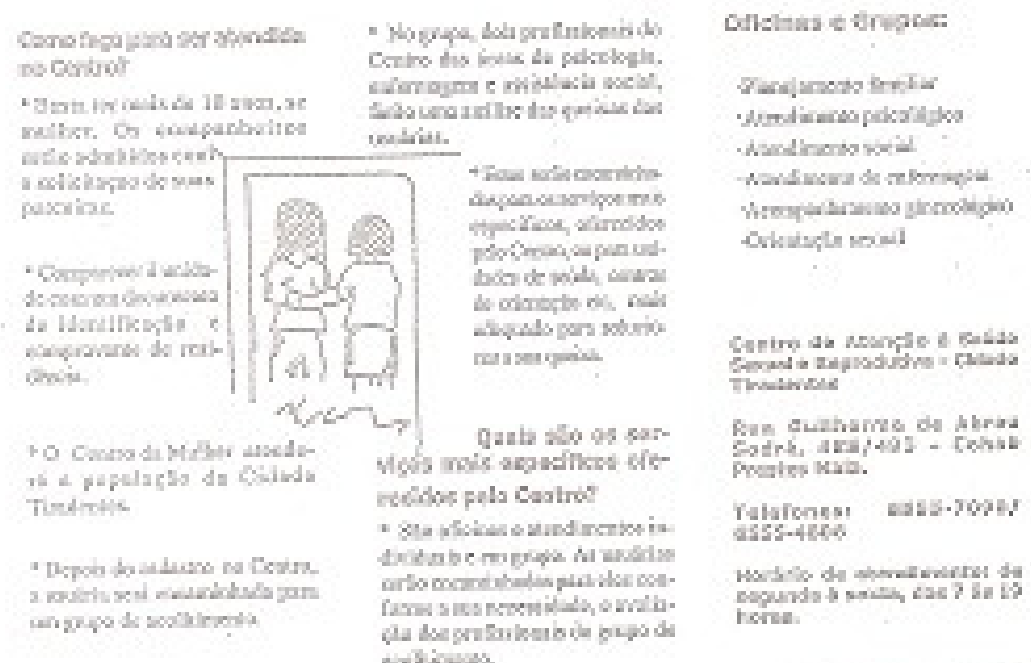

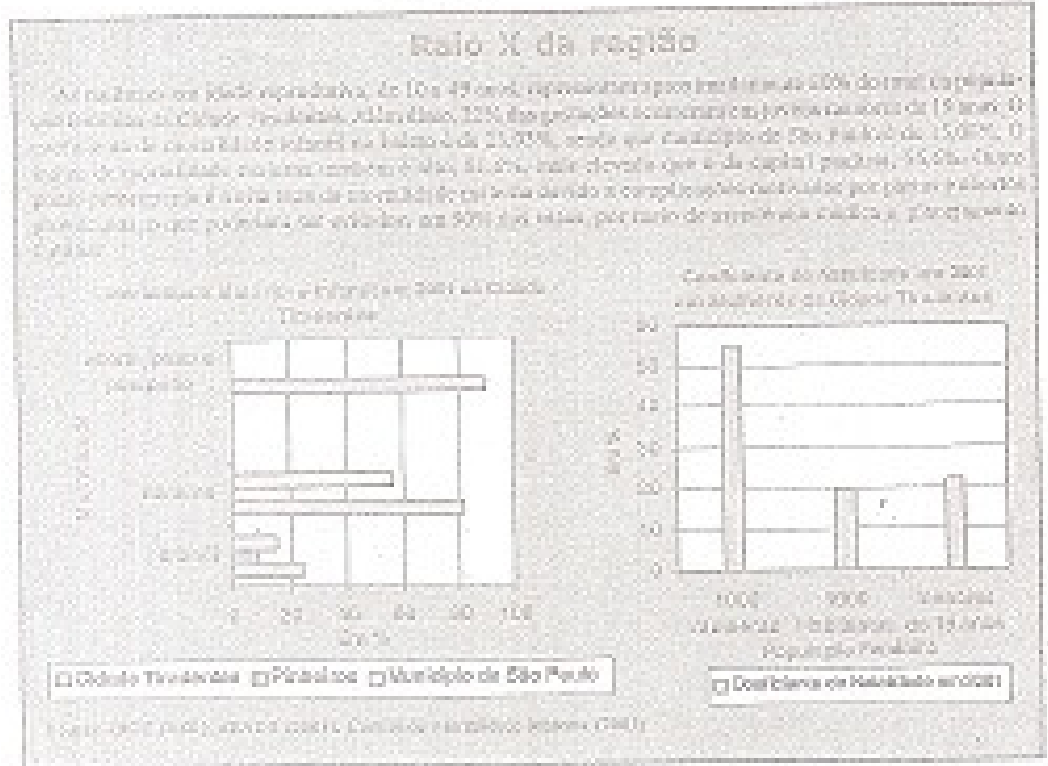

Boletim Informativo com orientações sobre como ser atendida e dados estatísticos da região. 


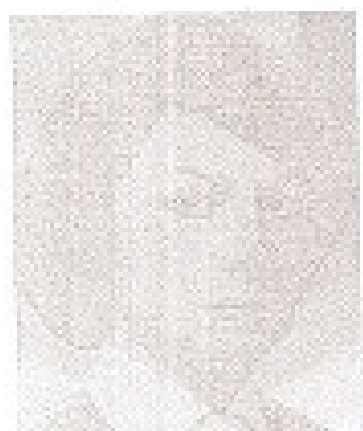

Wat mainilap Im lixs:

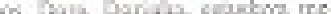

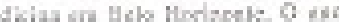

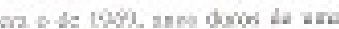

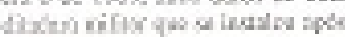



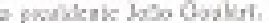

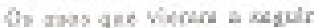

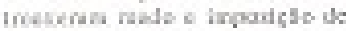

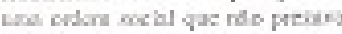

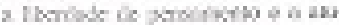

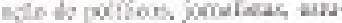

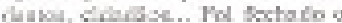

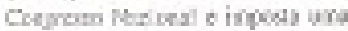

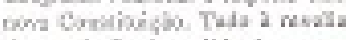

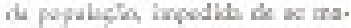

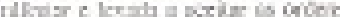
undth bo king whe.

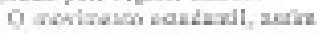

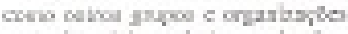

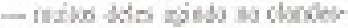

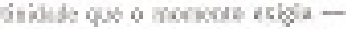

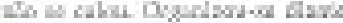

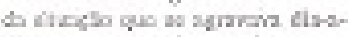

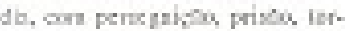

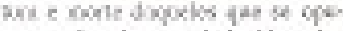

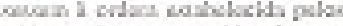

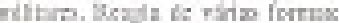

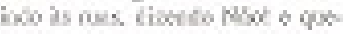

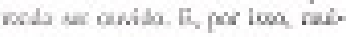

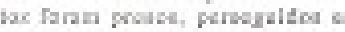
morian.

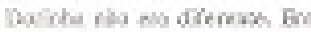

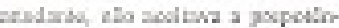

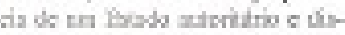

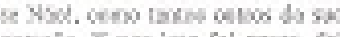

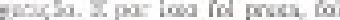

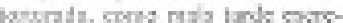

Dora, Dorinha, Maria Auxiliadora Lara Barcelos

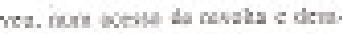
wh

Yri o mbath A w



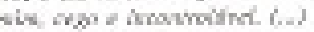
Fone hamoutris the do



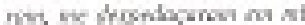

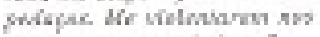

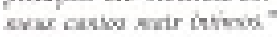

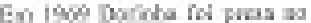

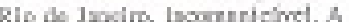

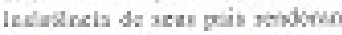
apues astors Biphos ribu

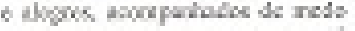

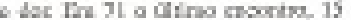

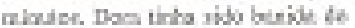

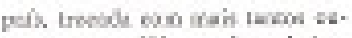
mo rove Mism pis ariaba.

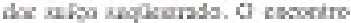

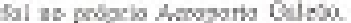

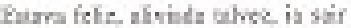

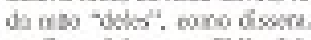

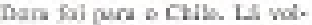

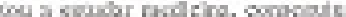

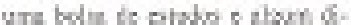

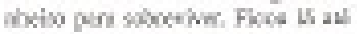
Iv1, as a gries du Find ape

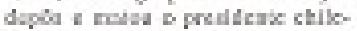

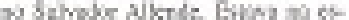

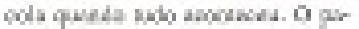

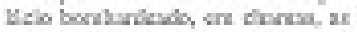

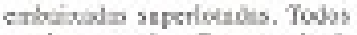

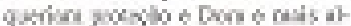

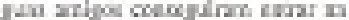

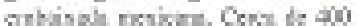

Boletim Informativo com história de Maria Auxiliadora Lara Barcellos. 